Universidade de Brasília

Faculdade de Economia, Administração, Contabilidade e Ciência da Informação e Documentação - FACE.

Departamento de Economia

\title{
MOEDAS DE INVOICE NAS EXPORTAÇÕES DO BRASIL: PADRÃO DE USO E EFEITO SOBRE A DINÂMICA DE PREÇOS
}

Dissertação de Mestrado

Autor: Fernando Ryu Ramos Kawaoka

Orientador: Prof. Dr. Roberto Ellery

Brasília

Novembro de 2014 
Universidade de Brasília

Faculdade de Economia, Administração, Contabilidade e Ciência da Informação e Documentação - FACE.

Departamento de Economia

\title{
MOEDAS DE INVOICE NAS EXPORTAÇÕES DO BRASIL: PADRÃO DE USO E EFEITO SOBRE A DINÂMICA DE PREÇOS
}

\author{
Dissertação apresentada como \\ requisito parcial para obtenção do grau de \\ Mestre em Ciências Econômicas pela \\ Universidade de Brasília.
}

Autor: Fernando Ryu Ramos Kawaoka

Banca Examinadora:

Prof. Dr. Roberto Ellery (Orientador)

Prof. Dr. Antonio Nascimento Junior

Prof. Dr. Victor Gomes e Silva

\section{Brasília}

Novembro de 2014 
Ao meu avô Haruhiko e ao meu tio Yodo. 


\section{AGRADECIMENTOS}

À Universidade de Brasília, pela oportunidade de participar do programa de mestrado acadêmico em ciências econômicas.

Ao meu orientador, professor Roberto Ellery, por sua contribuição à dissertação.

Ao Banco Central do Brasil e aos colegas do Depec, pelo apoio na realização do mestrado e pelo estímulo constante ao aprendizado.

Aos meus amigos e à minha família, pela compreensão nos momentos de ausência. 


\section{RESUMO}

O objetivo principal deste trabalho é caracterizar o uso de moedas de invoice nas exportações do Brasil, e seu efeito sobre o pass-through de câmbio para os preços de exportação. O estudo é baseado em microdados do Siscomex Exportação que identificam individualmente cada transação realizada no período 1999-2011. O uso das moedas de invoice é caracterizado através da agregação dos microdados segundo dimensões associadas ao produto exportado, à firma exportadora, ou ao país de destino. Para algumas dimensões, a evolução temporal do uso das moedas de invoice também é apresentado. Os resultados indicam que o dólar é, em larga medida, predominante nas exportações brasileiras. $\mathrm{O}$ euro tem papel relevante nas exportações de bens não-homogêneos para a União Europeia; e o real tem participação restrita a operações de baixo valor, em exportações para países do Mercosul e Bolívia. Os resultados são consistentes com resultados teóricos e empíricos da literatura de currency choice no comércio exterior. A análise dinâmica dos preços de exportação segue a literatura recente e explora a diferença de pass-through de câmbio em função da moeda de invoice da exportação. Os resultados indicam que, no curto prazo, os preços são rígidos na moeda de invoice. No longo prazo, os preço de exportações se ajustam em resposta às variações da taxa de câmbio, mas ainda é possível observar diferenças no pass-through entre exportações com moeda de invoice diferente.

Palavras Chave: pass-through de câmbio, moedas de invoice, currency choice. 


\begin{abstract}
The main purpose of this dissertation is to describe the use of different invoice currencies by Brazilian exports, as well as its effect on the exchange rate pass-through to export prices. The analysis is based on microdata from Siscomex Exportação which identify individual export transactions that took place between 1999 and 2011. The use of invoice currencies is described through aggregations of microdata by different dimensions, associated with the exported product, the exporting firm, or the destination country. For some of these dimensions the yearly change in invoice currency use is also presented. The results indicate that the US dollar is by a large margin dominant in Brazilian exports. The euro also plays a relevant role in exports of non-homogeneous goods to the European Union; and the use of the Brazilian real is limited to low value transactions destined for Bolivia or one of the original Mercosul countries. This results are consistent with theoretical and empirical results of the literature on currency choice in international trade. The analysis of export price dynamics follows the recent literature and explores the difference in exchange rate pass-through as a function of the invoice currency used. The results indicate that in the short run prices are rigid in the invoice currency. The results also suggest that in the long run export prices respond to exchange rate variations, but that it is still possible to observe differences in pass-through between exports that use different invoice currencies.
\end{abstract}

Key words: exchange rate pass-through, invoice currency, currency choice. 


\section{SUMÁRIO}

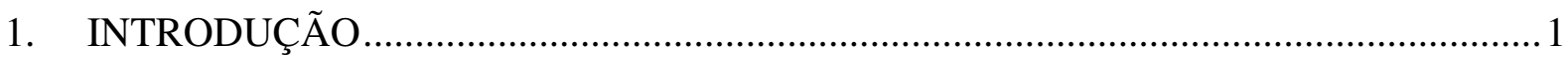

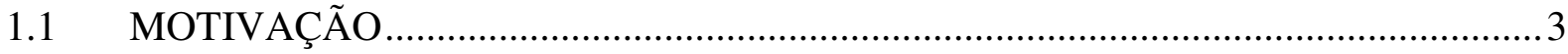

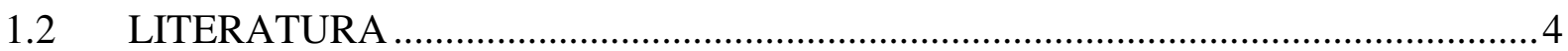

1.2.1 LOP, PPP, PASS-THROUGH DE CÂMBIO, E PTM …............................................

1.2.2 PASS-THROUGH DE CÂMBIO NA LITERATURA RECENTE ............................ 9

2. BASES DE DADOS E TABELAS DE CLASSIFICAÇÃO DE PRODUTOS ...............21

2.1 SISCOMEX EXPORTAÇÃO ......................................................................... 21

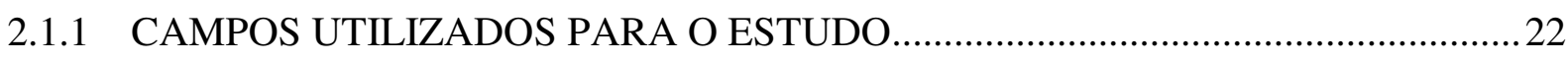

2.1.2 REGISTROS DE EXPORTAÇÃO E BALANÇA COMERCIAL ..............................27

2.2 CENSO DE CAPITAIS ESTRANGEIROS NO BRASIL ....................................28

2.3 CLASSIFICAÇÃO POR FATOR AGREGADO …................................................29

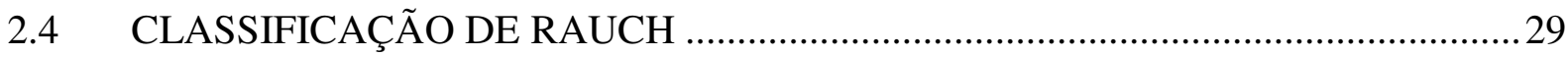

3. MOEDAS DE INVOICE NAS EXPORTAÇÕES BRASILEIRAS …...........................31

3.1 DESTINO DAS EXPORTAÇÕES E MOEDAS DE PAGAMENTOS ......................32

3.2 FATOR AGREGADO E MOEDAS DE PAGAMENTO .........................................39

3.3 DIFERENCIAÇÃO DE BENS E MOEDAS DE PAGAMENTO...............................41

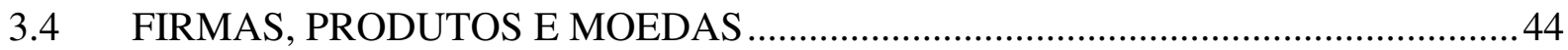

3.5 MOEDAS DE INVOICE POR DIVISÃO DA CNAE E POR CAPÍTULO NCM .....50

3.6 MOEDA DE INVOICE, TAMANHO E FREQUÊNCIA DAS EXPORTAÇÕES .....52

3.7 MOEDA DE INVOICE E INVESTIMENTO ESTRANGEIRO DIRETO .................54

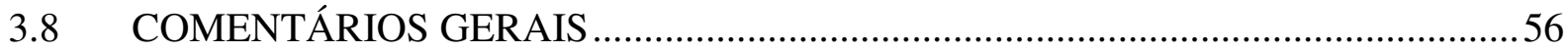

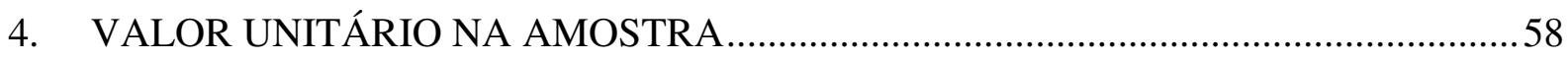

4.1 CONSTRUÇÃO DE VALORES UNITÁRIOS ..........................................................58 
4.2 VARIÂNCIA DO VALOR UNITÁRIO EXPLICADA PELA FIRMA, PRODUTO E

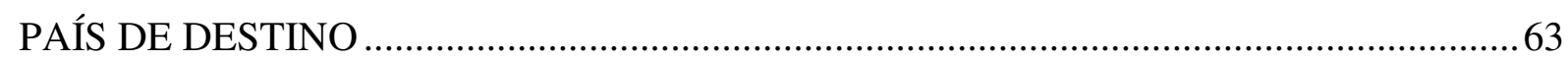

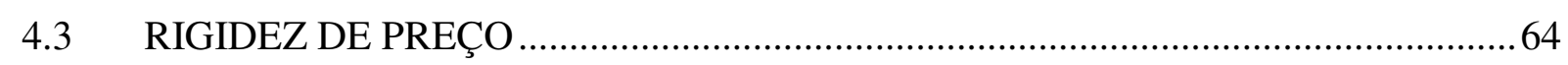

5. DINÂMICA DO PASS-THROUGH EM FUNÇÃO DA MOEDA DE INVOICE.........67

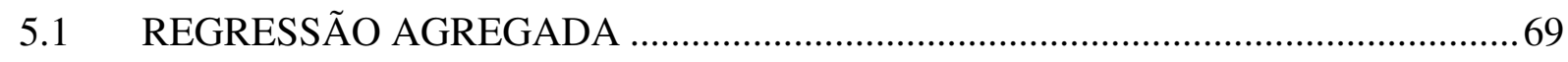

5.1.1 CONSTRUÇÃO DOS ÍNDICES DE PREÇO AGREGADOS ................................. 70

5.1.2 ESTIMATIVA DA RESPOSTA DINÂMICA DOS PREÇOS DE EXPORTAÇÃO

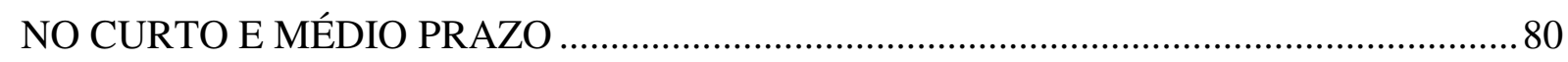

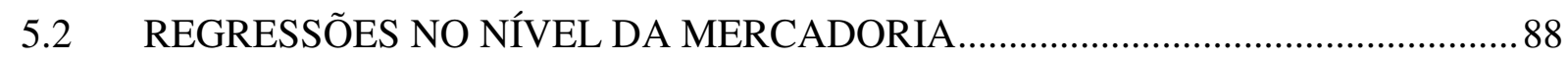

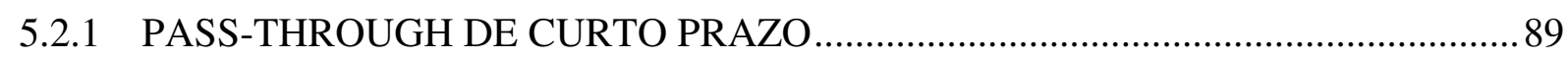

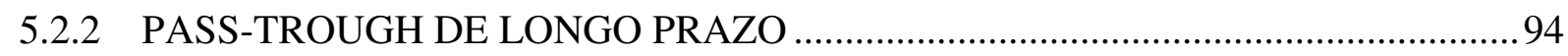

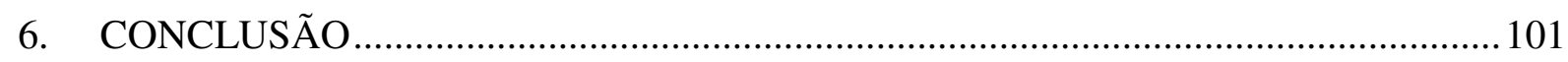

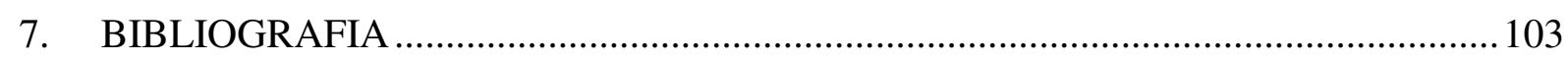




\section{LISTA DE FIGURAS}

Figura 1: Participação do BRL nas exportações brasileiras para o Mercosul. 38

Figura 2: BRL nas exportações brasileiras para o Mercosul - participação em valor, por país. 38

Figura 3: EUR nas exportações brasileiras para a União Europeia. 39

Figura 4: Moedas de pagamento por firma (CNPJ 8 dígitos) - predominância por valor. ......46 Figura 5: Moedas de pagamento por NCM (8 dígitos) - predominância por quantidade........47

Figura 6: Moedas de pagamento por NCM (8 dígitos) - predominância por valor.

Figura 7: Moedas de pagamento por par firma-NCM (8dígitos/8dígitos) - predominância por valor. 48

Figura 8: Moedas de pagamento por firma (CNPJ 8 dígitos), participação ponderada pelo valor das operações - predominância na moeda por critério de valor.

Figura 9: Moedas de pagamento por NCM (8 dígitos), participação ponderada pelo valor das operações - predominância na moeda por critério de valor.

Figura 10: Moedas de pagamento por par Firma-NCM (8dígitos/8dígitos), participação ponderada pelo valor das operações - predominância na moeda por critério de valor.

Figura 11: Frequência de ocorrência de registros com mercadorias idênticas (NCM-FirmaDestino) e mesma data de início do RE. 60

Figura 12: Frequência de ocorrência de registros com mercadorias idênticas (NCM-FirmaDestino) e mesmo mês de início do RE.

Figura 13: Dispersão de preços entre bens idênticos exportados no mesmo dia. 62

Figura 14: Dispersão de preços entre bens idênticos exportados no mesmo mês. 62

Figura 15: Taxas de câmbio nominais do USD e EUR em relação ao real (média de $2001=$ 100).

Figura 16: Razão entre as taxas de câmbio nominais do dólar e euro - $\log (\mathrm{USD} / \mathrm{EUR})$.

Figura 17: Índices de preço de exportações com invoice em EUR (log) - Estratégia 1...........72

Figura 18: Índices de preço de exportações com invoice em USD (log) - Estratégia 1...........73

Figura 19: Índices de preço de exportações com invoice em EUR (log) - estratégia 2............74

Figura 20: Índices de preço de exportações com invoice em USD (log) - estratégia 2............75

Figura 21: Índices de preço de exportações com invoice em EUR (log) - estratégia 3............76

Figura 22: Índices de preço de exportações com invoice em USD $(\log )$ - estratégia 3............77 
Figura 23: Índices de preço de exportação para invoice em EUR e USD - estratégia 2, exclusão de $25 \%$ das caudas. Índice iEUR25.2 convertido em dólar pela taxa média do mês.77 Figura 24: Razão entre os índices de preço (em euro) e a taxa de câmbio USD/EUR estratégia 2, exclusão de $25 \%$ das caudas, ambas as curvas em logaritmo. 78

Figura 25: Razão entre os índices de preço (em euro) e a taxa de câmbio USD/EUR estratégia 1, exclusão de $25 \%$ das caudas, ambas as curvas em logaritmo.

Figura 26: Razão entre os índices de preço (em euro) e a taxa de câmbio USD/EUR estratégia 3 , exclusão de $25 \%$ das caudas, ambas as curvas em logaritmo. 79

Figura 27: Pass-through de variações na taxa EUR/BRL para o preço de exportações com invoice em EUR - índice iEURm2x25.

Figura 28: Pass-through de variações na taxa EUR/BRL para o preço de exportações com invoice em EUR. Índices utilizados são indicados abaixo de cada gráfico. 83

Figura 29: Pass-through de variações na taxa dólar-real para o preço de exportações com invoice em USD - índice iUSDm2x25. 84

Figura 30: Pass-through de variações na taxa euro-dólar para o preço de exportações com invoice em USD - índice iUSDm2x25.

Figura 31: Pass-through de variações na taxa dólar-real para o preço de exportações com invoice em USD. Índices utilizados são indicados abaixo de cada gráfico. 86

Figura 32: Pass-through de variações na taxa euro-dólar para o preço de exportações com invoice em USD. Índices utilizados são indicados abaixo de cada gráfico. 87 


\section{LISTA DE TABELAS}

Tabela 1: Campos do Siscomex Exportação utilizados no estudo.

Tabela 2: Exportação por país de destino - comparação entre total na amostra e total na balança comercial (MDIC).

Tabela 3: Moedas de pagamento na exportação, por bloco de destino - participação em valor das exportações.

Tabela 4: Moedas de pagamento na exportação, por bloco de destino - participação em quantidade de operações.

Tabela 5: Moedas de pagamento na exportação - países do Mercosul e Bolívia.

Tabela 6: Moedas de pagamento na exportação - países com participação relevante do euro entre as moedas de pagamento.

Tabela 7: Moedas de pagamento na exportação, por fator agregado - participação em valor. 39 Tabela 8: Moedas de pagamento na exportação, por fator agregado - participação em quantidade de operações.

Tabela 9: Moedas de pagamento na exportação para a União Europeia - participação por fator agregado.

Tabela 10: Moedas de pagamento na exportação para Argentina, Paraguai, Uruguai e Bolívia participação por fator agregado.

Tabela 11 : Moedas de pagamento na exportação, de acordo com a classificação liberal de Rauch - participação em valor.

Tabela 12: Moedas de pagamento na exportação, de acordo com a classificação liberal de Rauch - participação em quantidade de operações.

Tabela 13 : Moedas de pagamento na exportação para a União Europeia, de acordo com a classificação liberal de Rauch.

Tabela 14: Moedas de pagamento na exportação para a União Europeia, de acordo com a classificação conservadora de Rauch.

Tabela 15: Moedas de pagamento na exportação para o Mercosul e Bolívia, de acordo com a classificação liberal de Rauch.

Tabela 16: Participação do EUR e do USD em função do valor total exportado pela firma (definida pelo CNPJ com 8 dígitos).

Tabela 17: Participação do EUR e do USD em função da frequência de exportação da firma (definida pelo CNPJ com 8 dígitos). 
Tabela 18: Participação do EUR e do USD em função da presença de capital estrangeiro na

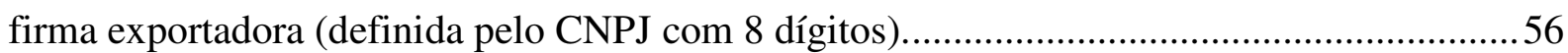

Tabela 19: Variação $\left(\mathrm{R}^{2}\right)$ no logaritmo do valor unitário explicada por efeitos fixos..............64

Tabela 20: Rigidez de preço entre transações consecutivas - tolerância de $0,1 \%$..................65

Tabela 21: Rigidez de preço entre transações consecutivas - tolerância de $0,2 \%$...................65

Tabela 22: Rigidez de preço entre transações consecutivas - tolerância de $0,5 \%$...................66

Tabela 23: Rigidez de preço entre transações consecutivas - bens diferenciados e tolerância de $0,2 \%$.

Tabela 24: Coeficientes de pass-through de curto prazo para exportações com invoice em moeda local e moeda veículo.

Tabela 25: Coeficientes de pass-through de longo prazo para exportações com invoice em moeda local e moeda veículo

Tabela 26: Coeficientes de pass-through de longo prazo para exportações com invoice em moeda local e moeda veículo - regressões com controle pelo IPA-M. 97

Tabela 27: Coeficientes de pass-through de longo prazo para exportações com invoice em moeda local e moeda veículo, com intervalo de 18 a 23 meses.

Tabela 28: Coeficientes de pass-through de longo prazo para exportações com invoice em moeda local e moeda veículo, com intervalo de 24 a 35 meses.

Tabela 29: Coeficientes de pass-through de longo prazo para exportações com invoice em moeda local e moeda veículo, com intervalo de 36 a 47 meses. 100

Tabela 30: Enquadramentos incluídos no estudo. 107 


\section{INTRODUÇÃO}

A crescente disponibilidade de bases de dados tornou possível nos últimos 20 anos a investigação do comportamento econômico dos agentes de forma mais desagregada, a partir de microdados.

Seguindo essa tendência, a proposta desta dissertação é utilizar a base de dados do SISCOMEX e outras bases de dados auxiliares para caracterizar o comportamento da firma exportadora no Brasil.

Entre os trabalhos recentes nesta linha é possível citar o artigo de Eaton et alii (2004), que utiliza dados da França para mostrar que firmas exportadoras são minoria entre as firmas francesas, que elas tendem a ser mais produtivas e maiores, e que elas normalmente exportam apenas uma fração pequena da sua produção.

Gomes e Ellery (2007) e Araújo et al (2010) exploram dados do SISCOMEX e da PIA para caracterizar o comportamento de firmas exportadoras no caso brasileiro, e encontram padrões similares àqueles descritos por Eaton et al (2004) para o caso francês.

Enquanto os trabalhos acima destacam, em resumo, o perfil da firma exportadora em termos de tamanho, produtividade, e acesso a mercados, uma outra linha de estudos explora bases de dados similares para entender o comportamento dos preços no comércio internacional. Três exemplos desta literatura são Gopinath et al (2010), com dados de importação nos Estados Unidos, Berman et al (2012), com dados de exportação de firmas francesas, e Fabling e Sanderson (2013), com dados de exportação da Nova Zelândia.

Seguindo esta linha de pesquisa, esta dissertação trata da resposta dos preços de exportação de firmas brasileiras a variações na taxa de câmbio (pass-through de câmbio). Mais especificamente, a dissertação investiga se esta resposta depende da moeda em que as mercadorias são negociadas. Os resultados da investigação confirmam aqueles obtidos por outros autores: no curto prazo os preços de exportação apresentam rigidez na moeda de invoice em que são negociados.

As seções 1.1 e 1.2 contextualizam a análise desenvolvida na dissertação dentro da literatura mais geral sobre preços no comércio internacional, e, mais recentemente, dentro da literatura que investiga a formação de preços com base em dados mais desagregados. A seção 
2 descreve as bases de dados e tabelas de classificação utilizadas na dissertação, com ênfase na descrição do Siscomex Exportação. A seção 3 descreve a evolução do uso do real, dólar, e euro como moedas de invoice das exportações brasileiras no período 1999-2010, para uma amostra geral de países, e no período 2001-2011, para as principais economias da União Europeia. Também apresenta desagregações por tipo de bem exportado e país de destino. A seção 4 apresenta uma análise sobre a variação dos valores unitários das mercadorias em função da mercadoria exportada, do país de destino e da firma exportadora, e apresenta um quadro indicativo da prevalência da rigidez no preço das exportações. A seção 5 faz uma análise da dinâmica dos preços de exportação, em função da moeda de invoice utilizada. A seção 6 conclui a dissertação.

A lista a seguir apresenta alguns termos e abreviaturas que são utilizados sistematicamente no texto, tabelas e gráficos.

USD, EUR, BRL: Dólar americano, euro e real. Sem qualificações, dólar faz referência à moeda americana.

Pass-through: Sem qualificações, indica o pass-through de variações no câmbio para o preço das exportações na moeda do país importador. Por convenção, o pass-through é definido como completo no caso em que toda variação cambial é transmitida para o preço final na moeda do importador; e nulo no caso em que variações cambiais não impactam os preços na moeda do importador. O pass-through completo é equivalente ao caso de precificação na moeda do produtor (PCP, producer currency pricing), enquanto o pass-through nulo equivale ao caso oposto, de precificação na moeda do importador (LCP, local currency pricing).

Moeda de invoice: Moeda na qual as exportações são contratadas, de acordo com os registros alfandegários. Ao longo do texto, fica latente a hipótese de que a moeda na qual os contratos são fechados é a moeda na qual a firma precifica seus produtos, embora as duas não sejam necessariamente as mesmas. Friberg e Wilander (2007), em questionários aplicados a firmas exportadoras da Suécia, observam que, na maioria dos casos, as firmas tendem a utilizar a mesma moeda na precificação, nos contratos, e no pagamento de suas exportações. 
Moeda veículo: moeda de invoice que não seja aquela dos países produtor e exportador. Os casos típicos são o dólar (para o comércio internacional em geral) e o euro (para o comércio com países adjacentes à Zona do Euro).

Mercosul: No texto, o termo Mercosul faz referência aos membros plenos da formação inicial do bloco - Paraguai, Uruguai, Argentina, Brasil. Não inclui a Venezuela, integrada ao bloco em julho de 2012, e países associados (Chile, Bolívia, Peru, Colômbia, Equador).

União Europeia e Zona do Euro: No texto, o termo União Europeia faz referência aos membros do bloco em sua formação no ano de 2007. A escolha não tem muita relevância na prática, uma vez que os maiores parceiros comerciais do Brasil já faziam parte do bloco desde meados dos anos 1990. O termo Zona do Euro faz referência à composição da união monetária no ano de 2001. Com exceção da Grécia, os demais países já faziam parte da união monetária em 1999, quando a moeda única foi introduzida.

\subsection{MOTIVAÇÃO}

A literatura econômica sobre o pass-through de câmbio está em grande medida vinculada a temas macroeconômicos. Na década de 70, com o fim do sistema de Bretton Woods e o início da flutuação das taxas de câmbio nas principais economias mundiais, a pesquisa sobre o pass-through estava associada à pesquisa sobre a dinâmica da balança comercial. A velocidade e o grau de ajuste dos preços às variações no câmbio ajudariam a explicar a resposta de exportações e importações em termos de valor e de quantidade. Mais recentemente a pesquisa sobre o pass-through de câmbio aparece associada à pesquisa sobre a transmissão de choques internacionais para a inflação doméstica.

Quando existe rigidez de preço no comércio internacional a moeda em que as mercadorias são precificadas assume papel relevante na determinação do pass-through de câmbio. Preços rígidos na moeda do importador (local currency pricing) implicam que toda a variação cambial é absorvida pela firma exportadora, ainda que apenas no curto prazo. Da mesma forma, preços rígidos na moeda do exportador (producer currency pricing) implicam que toda a variação cambial é absorvida pela firma importadora. Dado seu efeito na 
transmissão de choques internacionais para a economia doméstica, é importante entender como as firmas escolhem a moeda em que precificam suas exportações.

Para o caso brasileiro, a dissertação tem contribuição limitada do ponto de vista macroeconômico, uma vez que a quase totalidade das exportações brasileiras utiliza o dólar americano como moeda de pagamento. Conforme os resultados apresentados na seção 3.1, o dólar foi a moeda de invoice em 95\% das exportações em valor no período 1999-2010, enquanto o euro e o real foram utilizados em $4 \%$ e $0,2 \%$ das exportações, respectivamente. Assim, o comportamento agregado dos preços de exportação brasileiros podem ser analisados sem levar em consideração a heterogeneidade na moeda de invoice.

Apesar da prevalência do dólar nas exportações brasileiras em geral, é possível observar participação relevante do euro nas exportações que têm como destino a União Europeia, em especial no caso da exportação de bens diferenciados (i.e. que não sejam commodities). A dissertação utiliza este subgrupo de operações para comparar o comportamento dos preços de exportação em função da moeda de invoice: euro ou dólar. Os resultados empíricos para o caso das exportações brasileiras são importantes em função da escassez de informações sobre a utilização de moedas de invoice no comércio exterior, em particular no nível de desagregação disponível nos microdados do Siscomex e para o caso de países em desenvolvimento.

\subsection{LITERATURA}

Conforme observam Goldberg e Knetter (1997), a literatura econômica sobre a relação entre câmbio e preços é numerosa. Os autores relatam ter encontrado cerca de 700 artigos com um dos temas "Law of one Price", "Purchasing Power Parity", "Exchange Rate PassThrough", e "Pricing-To-Market". O próprio artigo de Goldberg e Knetter retorna cerca de 1300 citações no Google Scholar. O artigo de Menon (1995), que faz um levantamento da literatura sobre o pass-through de câmbio, retorna cerca de 360 citações no mesmo mecanismo de busca.

Esta seção pretende situar a dissertação dentro da literatura à qual ambos os artigos fazem referência. A seção 1.2.1 segue Goldberg e Knetter (1997) e Menon (1995), e discute a relação entre os grandes temas Law of One Price, Purchasing Power Parity, Exchange Rate Pass-Through, e Pricing-To-Market. Em seguida, a seção 1.2.2 apresenta em maior detalhe os 
artigos sobre pass-through que têm relação mais estreita com a dissertação. Estes artigos, em geral mais recentes, compartilham a análise empírica baseada em microdados ao nível da firma ou da transação, o que permite observar com mais detalhe a heterogeneidade do comportamento dos preços no comércio internacional.

\subsubsection{LOP, PPP, PASS-THROUGH DE CÂMBIO, E PTM}

Esta seção contextualiza a discussão do pass-through de câmbio dentro da literatura mais geral sobre o comportamento dos preços no comércio internacional, seguindo principalmente a apresentação de Goldberg e Knetter (1997) e de Menon (1995).

A lei do preço único (Law of One Price, ou LOP) é a hipótese segundo a qual o mesmo bem deve ter preços idênticos em dois países diferentes. Seja $p_{i}$ o preço do bem $i$ no país $A$, na moeda de $\mathrm{A}$, e $p_{i}^{*}$ o preço do mesmo bem no país $B$, na moeda de $B$. Seja $E$ a taxa de câmbio entre os dois países. A lei do preço único pode ser descrita na forma

$$
p_{i}=E \cdot p_{i}^{*}
$$

Se a relação for satisfeita para todos os bens nos dois países, Goldberg e Knetter (1997) concluem que a paridade do poder de compra (Purchasing Power Parity, PPP) é válida na sua versão absoluta:

$$
P=E \cdot P^{*},
$$

em que $P$ e $P^{*}$ são índices de preço nos dois países. Rogoff (1996) adverte que mesmo a formulação acima não é livre de problemas, uma vez que a construção dos índices a partir do preço dos bens individuais depende, entre outros fatores, dos pesos de ponderação em cada país - pesos que, em geral, são diferentes.

A LOP depende de condições fortes para ser observada. Em particular requer custos de transporte, revenda e distribuição iguais a zero. Como não se espera que essas condições sejam satisfeitas, utiliza-se frequentemente uma versão mais fraca da hipótese de PPP. A sua formulação relativa supõe que o preços no país A são uma fração constante $\alpha$ dos preços no país B:

$$
p_{i}=\alpha \cdot E \cdot p_{i}^{*}
$$




$$
P=\alpha \cdot E \cdot P^{*}
$$

Rogoff (1996), por outro lado, justifica o uso da versão relativa da PPP em função da diferença de base entre os índices de preço de cada país.

Em relação às evidências empíricas da PPP, Rogoff (1996) observa que os resultados em geral mostram que a convergência de preços, se existe, se dá apenas no longo prazo. Uma série de abordagens parece indicar que os desvios da paridade têm meia vida entre 3 e 5 anos, i.e. são amortecidos a uma taxa anual próxima a 15\%. Por outro lado, muitos testes não conseguem rejeitar a hipótese de passeio aleatório no câmbio real.

Como também indica Rogoff (1996), a incapacidade de observar a PPP no curto e médio prazos está intimamente associada à falha da lei do preço único:

"...the law of one price [is] a central building block of PPP that posits that similar goods should sell for similar prices across countries. Most economists recognize that there are frequent violations of the law of one price, but those not familiar with recent research will probably be stunned by the pervasiveness of the disparities."

Do ponto de vista dos preços ao consumidor final, há uma série de razões pelas quais a lei do preço único não deva ser observada na prática. Entre elas, Rogoff (1996) e Goldberg e Knetter (1997) citam custos de transporte internacional, custos tarifários, barreiras não tarifárias, custos de distribuição e de revenda, custos de arbitragem, e, na inexistência de um mercado integrado para o bem, o pricing-to-market (ou PTM, a discriminação de preços no mercado internacional de acordo com o destino da mercadoria).

Goldberg e Knetter (1997) situam as pesquisas sobre a LOP e a PPP dentro da discussão sobre a validade do monetarismo global ${ }^{1}$, que, na sua forma mais básica, assume que os mercados internacionais são integrados e competitivos ${ }^{2}$.

\footnotetext{
${ }^{1}$ Global monetarism.
}

${ }^{2}$ Whitman (1975) apresenta um modelo simplificado do monetarismo global. O modelo é sustentado, entre outras, pela hipótese de arbitragem perfeita de mercadorias, de forma que vale a lei do preço único. Goldberg e Knetter (1997), concluindo a discussão sobre a LOP, também destacam a importância desta hipótese para o modelo do monetarismo global e a sua rejeição nos testes empíricos: "The consistent rejection of the LOP and PPP raised serious questions about global monetarism, but believers in an integrated, competitive paradigm viewed the evidence only as proof that goods whose prices were used in testing the LOP were not identical." 
Ainda segundo Goldberg e Knetter (1997), outros objetivos guiavam a pesquisa sobre a relação entre taxas de câmbio e preços nos anos 70 . Havia a necessidade de entender o efeito de variações nas taxas de câmbio sobre a inflação e sobre o ajuste da balança comercial. Em relação à balança comercial, em particular, a pesquisa sobre o pass-through de câmbio buscava determinar em que medida os preços no comércio internacional seguiam a hipótese mais simples da condição de Marshall-Lerner, com oferta de exportação perfeitamente elástica, e, consequentemente, preços constantes na moeda do exportador.

Menon (1995) também destaca a necessidade de entender o ajuste da balança comercial a variações na taxa de câmbio como motivação para a pesquisa do pass-through de câmbio. Em suas palavras,

"If exchange rate changes are not fully or substantially reflected in the selling prices of traded goods, then the anticipated quantity adjustment will be retarded even if the degree of demand elasticity is sufficiently large."

Goldberg e Knetter (1997) propõem um modelo de regressão genérico para ilustrar as diferenças de abordagem na investigação da relação entre câmbio e preços no comércio internacional:

\section{Equação 1}

$$
p_{t}=\alpha+\delta \cdot X_{t}+\gamma \cdot E_{t}+\varphi \cdot Z_{t}+\varepsilon_{t}
$$

$\mathrm{Na}$ estimação do pass-through de câmbio para os preços de importação, a variável $p_{t}$ mede os preços de importação (na moeda do país importador), $X_{t}$ é um controle para os custos das mercadorias (na moeda do exportador), $E_{t}$ é a taxa de câmbio (moeda do país importador em termos da moeda do país exportador), e $Z_{t}$ contém outras variáveis de controle, como medidas de renda do país importador e o preço de competidores. Nessa formulação, o passtrough é completo quando $\gamma=1$, e incompleto quando $\gamma<1$.

A equação acima pode ser reescrita do ponto de vista dos preços ao exportador. Quando $p_{t}$ mede preços de exportação (na moeda do país exportador), o pass-trough é completo quando $\gamma=0$, e incompleto quando $\gamma>0$.

De forma mais simplificada, Goldberg e Knetter (1997) também definem o passthrough de câmbio como "a variação percentual nos preços de importação em moeda local 
que resultam de uma variação de $1 \%$ na taxa de câmbio entre os países exportador e importador". Essa definição é seguida por Fabling e Sanderson (2013) e Gopinath e Rigobon (2007), em dois artigos que são discutidos em mais detalhes na seção 1.2.2.

Enquanto no modelo mais simples da condição de Marshall-Lerner o pass-through de câmbio é, por hipótese, completo $(\gamma=100 \%)$, Goldberg e Knetter (1997, pp 1249-1250) indicam que as pesquisas realizadas nos anos 80 com dados de importação dos Estados Unidos estimavam pass-through incompleto, na faixa de 60\%. Menon (1995, pp 224), analisando o resultado de 46 estudos sobre o tema, também indica que o pass-through incompleto é o resultado predominante:

Not only are exchange rate changes never fully reflected in prices in the majority of studies, but the lags corresponding to the partial pass-through process are quite extensive. The small number of studies that do find full pass-through generally point to even longer lags in the transmission of exchange rate changes to prices.

Em artigo mais recente, usando dados de importação dos Estados Unidos para o período 1993-2005, Gopinath e Rigobon (2007) encontram coeficientes de pass-through um pouco abaixo de 40\%. Também no caso de importações americanas, Goldberg e Campa (2002) encontram pass-through de $25 \%$ no curto prazo e de $40 \%$ no longo prazo. O mesmo estudo conclui que o pass-through parcial é o resultado típico no caso de preços de importação de países da OECD, ainda que a média de longo prazo para os países do grupo seja mais alta do que aquela para os Estados Unidos individualmente.

Na especificação de Goldberg e Knetter (1997), Equação 1, o controle do custo do exportador permite interpretar o coeficiente de pass-through como uma medida da variação do seu mark-up em função do câmbio. Na ausência de um controle para os custos do exportador, no entanto, o coeficiente captura tanto a variação do mark-up, quanto a variação do custo marginal das mercadorias em função do câmbio. Sem um controle adequado dos custos de produção, um baixo coeficiente de pass-through pode refletir simplesmente uma estrutura de produção com peso elevado de insumos importados, sem implicações para a lucratividade das firmas.

Enquanto um mercado internacional integrado implica que o mark-up das firmas exportadoras é igual para todos os países de destino, um mercado internacional segmentado por país permite que a firma exportadora ajuste seu mark-up em função do destino da 
mercadoria. O termo pricing-to-market (PTM) foi introduzido por Krugman (1986) para indicar esta modalidade de discriminação de preços no mercado internacional em resposta a variações nas taxas bilaterais de câmbio. De forma geral, Goldberg e Knetter (1997, pp 1277) concluem que a literatura apresenta evidências a favor da existência de pricing-to-market.

Vale destacar outras duas considerações feitas por Goldberg e Knetter (1997) a respeito da literatura de pricing-to-market. A primeira é que a maioria dos estudos sobre PTM utiliza regressões com preços em primeira diferença. Assim, um processo secular de convergência de preços internacionais, i.e. um processo de integração de mercados que parte de um estado inicial de dispersão de preços, pode, erroneamente, gerar evidências a favor da discriminação de preços entre mercados. A segunda observação, que também serve de motivação para a presente análise, é que o uso de diferentes moedas de invoice no comércio internacional associado à rigidez de preços pode favorecer ou mascarar a identificação do PTM, de forma que é necessário diferenciar as respostas de curto e longo prazos dos preços à variação do câmbio.

\subsubsection{PASS-THROUGH DE CÂMBIO NA LITERATURA RECENTE}

$\mathrm{Na}$ conclusão do seu levantamento de artigos empíricos sobre o pass-through de câmbio, Menon (1995) alerta para a escassez de estudos baseados em dados mais desagregados, ao nível de produto. A tabela 1 do artigo sugere que parte relevante dos estudos de pass-through analisados pelo autor utiliza preços de importação ou exportação agregados. Mesmo as pesquisas que utilizam dados mais desagregados partem de classificações de produtos no nível de 1, 2 ou 4 dígitos.

O destaque de Menon (1995) para a escassez de estudos que utilizem dados ao nível de produto é importante, em particular, pelas evidências de heterogeneidade no pass-through entre produtos diferentes nos estudos que partem de dados mais desagregados. Goldberg e Knetter (1997), ao tratar do pass-through para os preços de importação nos Estados Unidos, citam os resultados de Feenstra (1989), que apontam coeficientes de 63\% para a exportação de caminhões e de quase $100 \%$ para a exportação motocicletas por firmas japonesas. Dos artigos citados em Menon (1995), o artigo de Menon (1992), analisando exportações australianas, encontra pass-through quase completo para têxteis e produtos básicos de metal, 40\% para químicos, e 50\% para equipamentos de transporte; Alterman (1991), para 
exportações dos Estados Unidos, encontra pass-through de 37,4\% para químicos, 49,6\% para bens intermediários manufaturados, 148,2\% para maquinário e equipamentos de transporte, e 107,2\% para outros artigos manufaturados. Para importações dos Estados Unidos, encontra pass-through de 32,4\% para químicos, 57,4\% para bens intermediários manufaturados, 44,0\% para maquinário e equipamentos de transporte, e 52,9\% para outros artigos manufaturados.

Esta seção apresenta em mais detalhes a literatura recente de pass-through que serve de referência para a dissertação. Os artigos apresentados têm em comum a análise empírica baseada em dados ao nível da firma ou ao nível da transação, o que permite observar em mais detalhes a heterogeneidade de comportamento dos preços de exportação e importação. Em especial, são apresentados artigos que destacam o papel da moeda de invoice na resposta dos preços ao câmbio.

\subsubsection{Gopinath et al (2010): Currency Choice and Exchange Rate Pass-through}

O artigo de Gopinath et al (2010) e o artigo de Fabling e Sanderson (2013) são as duas principais referências para a dissertação. O artigo de Fabling e Sanderson (2013) é apresentado na seção 1.2.2.3.

A ideia do artigo de Gopinath et al (2010) é caracterizar o pass-through dos preços de importação nos Estados Unidos em função da moeda de invoice utilizada pelas firmas: moeda local (USD), ou moeda do produtor. Empiricamente, Gopinath et al (2010) apresentam resultados importantes:

o pass-through de curto prazo para mercadorias com preço em USD é, em média, muito menor do que o pass-through para mercadorias com preço na moeda do produtor;

a diferença de pass-through persiste mesmo após a primeira mudança de preço das mercadorias - $25 \%$ para mercadorias em USD e $95 \%$ para mercadorias na moeda do produtor, o que sugere que a diferença não deriva simplesmente da rigidez nominal de preços no curto prazo;

esta diferença de pass-through pode ser observada mesmo entre mercadorias classificadas no mesmo código de produto (no nível de 6 e 10 dígitos);

no longo prazo a diferença de pass-through entre os dois grupos de mercadoria é menor, mas ainda é da ordem de $50 \%$ e estatisticamente significante; 
mercadorias mais homogêneas tendem a ser precificadas em USD, enquanto mercadorias mais diferenciadas tendem a ter maior participação da moeda do produtor na precificação.

O principal ponto teórico do artigo é a discussão sobre a determinação endógena ou exógena da moeda de invoice no comércio internacional. Os autores argumentam que a evidência empírica sustenta a hipótese de que a moeda de invoice é uma escolha da firma, determinada endogenamente, em contraste com modelos usuais de macroeconomia internacional que assumem, de forma simplificada, que a moeda de invoice é determinada exogenamente.

A hipótese de escolha endógena é relevante uma vez que, na presença de rigidez, permite que os preços de curto prazo se aproximem dos preços flexíveis ótimos para a firma. Firmas que desejam pass-through baixo no curto prazo escolhem precificar sua exportação na moeda do importador, enquanto firmas que desejam pass-through elevado escolhem precificar suas vendas na própria moeda.

Nesse sentido, Gopinath et al (2010) propõem um modelo dinâmico de escolha da moeda de invoice em que a firma escolhe tanto o preço de exportação quanto a moeda de invoice. A cada período, de acordo com uma probabilidade exógena ${ }^{3}$, a firma recebe ou não a permissão de reajustar o preço e a moeda de invoice. Nesse modelo genérico a escolha de moeda ótima é função do pass-through desejado pela firma no intervalo de tempo em que não reajusta seus preços, em linha com o modelo estático em Engels (2006).

Em termos empíricos, é interessante destacar as características da base de dados utilizada por Gopinath et al (2010), em função das suas diferenças com a base utilizada na dissertação. A base de dados e o tratamento dos dados são explicados em mais detalhes em Gopinath e Rigobon (2008).

Gopinath et al (2010) utilizam microdados não publicados da pesquisa de preços de importação e exportação dos Estados Unidos, coletados pelo US Bureau of Labor Statistics (BLS) dentro do International Price Program desta agência.

Ao contrário de dados alfandegários, os dados do BLS são coletados com fins puramente estatísticos. Os índices de preço de exportação e importação foram implementados

\footnotetext{
${ }^{3}$ Os autores propõe um mecanismo com base em Calvo (1983).
} 
pelo BLS nos anos 80 e substituíram as séries do Bureau of The Census, que eram baseadas em valores unitários calculados a partir de registros alfandegários ${ }^{4}$.

Os dados cobrem o período de setembro de 1993 a abril de 2005 para importações e exportações. Apenas os dados sobre importações, no entanto, são analisados de forma mais detalhada, uma vez que a participação de moedas diferentes do USD nas exportações é muito reduzida.

Nos dados de importação, um bem é definido como a combinação de uma firma importadora com um produto (na classificação de 10 dígitos). Produtos de mesma classificação importados por firmas diferentes são considerados bens distintos. De forma análoga, nos dados de exportação um bem é definido como a combinação de uma firma exportadora com um produto. Seguindo essa definição, são pesquisados mensalmente pelo BLS cerca de 20.000 bens, incluindo exportação e importação.

Ao contrário de Fabling e Sanderson (2013), o artigo não leva em consideração a origem da mercadoria (nos dados de importação) ou o seu destino (nos dados de exportação) para definir o bem.

O preço pesquisado pelo BLS segue preferencialmente as condições FOB (Free On Board) nas importações e FAS (Free Alongside Ship) nas exportações. Nenhuma das duas condições inclui custos de frete, seguros de transporte, ou tarifas no país de destino.

Os respondentes devem reportar preços associados à primeira transação no mês de referência. Caso não haja transações no mês, o respondente deve responder a pesquisa com uma estimativa de preço. Gopinath et al (2010) descartam todos os preços estimados, mantendo apenas preços associados a transações. Nesse aspecto, os dados são similares aos utilizados nesta dissertação: o preço de um bem não é observado em todos os meses.

A série de preços para um bem individual pode ser interrompida por diversos motivos. Nos casos em que o bem é trocado por um substituto próximo, os autores ligam as séries dos dois produtos de forma a ter uma série contínua.

${ }^{4}$ A seção 4.1 discute os problemas associados ao uso de valores unitários como proxies de preço. Para detalhes sobre a implementação dos índices de preço de exportação e importação pelo BLS em substituição aos índices do Bureau of The Census, ver artigo de Alterman (1991). 
Os autores também excluem observações que impliquem mudanças muito bruscas de preço (de mais de 2 pontos logarítmicos), o que afeta cerca de $0,15 \%$ da amostra.

Um ponto mais relevante, Gopinath et al (2010) excluem observações associadas a transações intrafirma, uma vez que os preços nessas transações não necessariamente respondem a forças de mercado. A exclusão afeta $40 \%$ da amostra no caso das importações e $26 \%$ no caso das exportações.

Preços derivados de transações intrafirma são explicitamente identificados na base de dados do BLS, de forma que sua exclusão é trivial. Na base de dados do Siscomex Exportação, utilizada na dissertação, as transações intrafirma não são identificadas explicitamente.

$\mathrm{Na}$ análise de preços de importação, Gopinath et al (2010) selecionam apenas importações com origem em países com quantidade relevante de operações na sua própria moeda (Alemanha, Suíça, Itália, Japão, Reino Unido, Bélgica, França, Suécia, Espanha, Austrália, Holanda, e Canadá).

\subsubsection{Berman et al (2012): How do different exporters react to exchange rate changes?}

A proposta do artigo de Berman et al (2012) é analisar como as diferenças de produtividade das firmas exportadoras afetam sua resposta a variações na taxa de câmbio, tanto em termos de preço, quanto em termos de volume.

Os modelos teóricos discutidos no artigo levam a duas proposições:

A) a elasticidade dos preços de exportação em relação à taxa de câmbio é maior para firmas mais produtivas;

B) a elasticidade dos volumes de exportação em relação à taxa de câmbio é menor para firmas mais produtivas.

A proposição A indica que firmas mais produtivas tendem a absorver mais as variações da taxa de câmbio e, portanto, devem apresentar pass-through menor.

Os autores testam empiricamente as duas proposições utilizando dados de exportação de firmas francesas para o período 1995-2005. Ao contrário dos dados de Gopinath et al (2010), os dados de Berman et al (2012) derivam de informações alfandegárias. 
As informações básicas são o volume anual (em peso) e o valor anual (em euros) das exportações das firmas francesas, desagregadas por produto e destino. O produto é dado no nível de classificação de 8 dígitos, padrão para a União Europeia. Assim, enquanto Gopinath et al (2010) possuem dados efetivos de preço, Berman et al (2012) utilizam valores unitários ${ }^{5}$. A mesma estratégia é usada em Fabling e Sanderson (2013), e nesta dissertação.

Para medir a produtividade das firmas, são utilizadas informações de vendas, valor agregado, número de empregados, capital e número de destinos na exportação.

Os autores excluem exportações para a Zona do Euro (em função da baixa variância do câmbio real entre os países que adotam a moeda única), e exportações de firmas cuja atividade principal não seja industrial.

De forma a minimizar o ruído inerente ao uso de valores unitários como proxies de preço, são excluídas as observações que impliquem em variações atípicas. Os autores mantêm apenas as variações centrais, excluindo as $1 \%$ maiores e $1 \%$ menores do setor no ano.

Os resultados empíricos de Berman et al (2012) confirmam as duas proposições sobre a relação entre elasticidades de preço e volume a variações no câmbio real e a produtividade das firmas. Também é interessante notar que os autores encontram coeficientes médios de passthrough muito mais elevados do que aquele estimados por Gopinath et al (2010). Para as importações com origem na França, Gopinath et al (2010) encontram pass-through abaixo de $25 \%$ em um horizonte de 2 anos; Berman et al (2012) encontram pass-through de $92 \%$ na amostra geral, e de $64 \%$ nas exportações para os Estados Unidos.

Quanto à influência da moeda de invoice, os autores apenas indicam que a decisão da moeda de invoice e do grau de pricing-to-market são "similares" para a firma, sugerindo a moeda de invoice é determinada endogenamente.

\subsubsection{Fabling e Sanderson (2013): Export performance, invoice currency, and heterogeneous exchange rate pass-through}

O artigo de Fabling e Sanderson (2013) é a principal referência para a dissertação em termos do tratamento dos dados, em função da similaridade das duas bases de dados.

\footnotetext{
${ }^{5} \mathrm{O}$ valor unitário é dado pela divisão do valor do produto exportado por seu peso.
} 
Fabling e Sanderson (2013) utilizam dados alfandegários de exportação da Nova Zelândia para o período de abril de 2004 a dezembro de 2010. Os autores têm acesso aos microdados no nível da transação comercial, incluindo a identificação da firma exportadora, a quantidade e peso dos itens exportados, o valor total da transação em termos Free-On-Board, o país de destino, a moeda de invoice, e a classificação do produto no nível de 10 dígitos do Sistema Harmonizado. Essa base de transações comerciais é integrada com outras bases de informações sobre as firmas que permitem identificar o uso explícito de hedge cambial e a participação de capital estrangeiro nas firmas.

Enquanto Gopinath et al (2010) observam efetivamente os preços de exportação das firmas para um dado produto, Fabling e Sanderson (2013) trabalham com valores unitários, obtidos pela divisão simples entre o valor total da transação e a quantidade exportada. Para algumas classes de produto a quantidade é dada de acordo com uma unidade específica, definida pelo sistema de classificação (peso, litros, unidades). Para outras classes apenas o peso das mercadorias é informado. Para medir a quantidade das mercadorias, os autores utilizam preferencialmente a unidade definida pelo sistema de classificação, e, se esta não estiver disponível, o seu peso.

Diferentemente do padrão observado para os Estados Unidos, em que as importações usam essencialmente a moeda local (USD) ou a moeda do país exportador como moeda de invoice, as exportações da Nova Zelândia apresentam participação equilibrada entre a moeda local (NZD), a moeda do país importador, e moedas veículo. Dentre as moedas veículo, o dólar predomina entre as exportações em geral, e o euro predomina nas exportações para países europeus fora da Zona do Euro. Assim, enquanto Gopinath et al (2010) estimam coeficientes de pass-through específicos apenas para exportações em moeda local e na moeda do exportador, Fabling e Sanderson (2013) estimam, adicionalmente, coeficientes de passthrough nas moedas veículo.

A regressão básica do artigo é similar àquela utilizada por Gopinath et al (2010):

\section{Equação 2}

$$
\Delta P_{f c g t}=\beta \cdot \Delta e_{c t}+Z_{c g t} \cdot \gamma+\varepsilon_{f c g t}, \Delta \in\left\{\Delta_{S R}, \Delta_{L R}\right\}
$$

Na equação acima, $P_{f c g t}$ é o preço do produto $g$, da firma $f$, destinado ao país $c$, expresso na moeda local (NZD); $e_{c t}$ é a taxa nominal de câmbio entre a Nova Zelândia e o 
país de destino; e $\beta$ é o coeficiente de pass-through a ser estimado. Quando $\beta=0$, o preço do exportador em moeda local não varia, e o pass-through para os preços de importação é completo. Quando $\beta=1$, o preço do exportador em moeda local varia em linha com o câmbio, e o exportador absorve toda a variação cambial.

Fabling e Sanderson (2013) estimam dois conjuntos de coeficientes: o primeiro, de curto prazo (short-run, SR), é calculado para variações de preço e câmbio entre duas operações de exportação consecutivas da mesma mercadoria, desde que o intervalo entre elas não ultrapasse seis meses; o segundo conjunto de coeficientes, de longo prazo (long-run, LR), é baseado nas variações entre a primeira e a última exportação de uma mesma mercadoria. Vale ressaltar que a mercadoria, neste caso, é definida pelo trio Código de produto-FirmaPaís de destino. O código de produto é utilizado na sua maior desagregação, de 10 dígitos.

$\mathrm{O}$ vetor $Z_{\text {cgt }}$ contém variáveis de controle: i) a variação dos índices de preço na Nova Zelândia e no país de destino; ii) a variação do PIB no país de destino; e iii) dummies para cada dupla País de destino-Código de Produto de 4 dígitos.

A regressão de curto prazo tem uma diferença fundamental em relação àquela utilizada por Gopinath et al (2010). Gopinath et al (2010), por trabalharem com dados de preços obtidos diretamente da pesquisa do BLS, conseguem identificar os pontos exatos em que há mudança nos preços. Dessa forma, estimam o coeficiente de pass-through condicional à primeira mudança de preços ${ }^{6}$.

No artigo de Fabling e Sanderson (2013) o uso de valores unitários dificulta a identificação exata do ponto de mudança de preços. Em face desta limitação, os autores não condicionam a regressão de curto prazo a uma mudança de preços.

A regressão básica dada pela Equação 2 é modificada para permitir que o coeficiente de pass-through varie para moedas de invoice diferentes, para firmas com performance diferente, para grupos de bens diferentes, para o uso de hedge e para a presença de investimento direto estrangeiro na firma.

${ }^{6}$ Gopinath et al (2010) utilizam o termo medium-run pass-through (MRPT) para designar o pass-through condicional à primeira mudança de preço, para diferenciá-lo do pass-through de mais curto prazo, calculado no período de rigidez nominal estrita. 
Os resultados empíricos obtidos por Fabling e Sanderson (2013) são comparáveis àqueles obtidos por Berman et al (2012) e Gopinath et al (2010). No curto prazo, o passthrough é definido essencialmente pela moeda de invoice escolhida pelo exportador: exportações em NZD apresentam pass-through completo (do ponto de vista do importador); exportações na moeda do importador apresentam pass-through nulo; e exportações em moedas veículo apresentam pass-through intermediário. Ainda no curto prazo, após controlar pela moeda de invoice, não há evidência de variação no pass-through para firmas com performance diferente.

$\mathrm{Na}$ regressão de longo prazo, os coeficientes de pass-through nas diversas moedas de invoice não convergem completamente para um mesmo nível. Na moeda do importador, o pass-through permanece significativamente menor, indicando que a variação do câmbio é absorvida em sua maior parte pelo exportador. Na moeda do exportador e nas moedas veículo os coeficientes de pass-through deixam de ser significativamente diferentes um do outro e indicam que a maior parte da variação cambial é absorvida pelo importador (pass-through para os preços do importador próximo de $83 \%$ ).

\subsubsection{Outros artigos}

As principais referências para a dissertação do ponto de vista da análise empírica são os artigos de Fabling e Sanderson (2013) e Gopinath et al (2010). Nesta seção são apresentados outras pesquisas recentes que também exploram o comportamento da firma exportadora com base em microdados. A ênfase na descrição a seguir é na base de dados utilizada e nos resultados obtidos.

Goldberg e Tille (2009) ${ }^{7}$ utilizam dados alfandegários de importação do Canadá entre 2002 e 2009. Os dados cobrem todas as transações realizadas no período e identificam, para cada transação, o país de origem, a classificação da mercadoria no Sistema Harmonizado (10 dígitos), a quantidade da mercadoria, o valor total da transação, e a moeda de invoice. Os autores não têm acesso à identidade das firmas importadora e exportadora.

A proposta de Goldberg e Tille (2009) é avaliar empiricamente os determinantes da escolha da moeda de invoice entre a moeda local (dólar canadense), a moeda do produtor, e

\footnotetext{
${ }^{7}$ Goldberg e Tille (2009), "Micro, macro, and strategic forces in international trade invoicing".
} 
uma moeda veículo (o dólar americano). Os autores trabalham com seis categorias de variáveis explicativas: i) fatores de "coalescência", que indicam a tendência das firmas de estabelecer preços em uma moeda comum, como no caso do comércio de bens homogêneos; ii) variáveis ligadas ao poder de barganha das firmas importadora e exportadora, para avaliar a hipótese de que as firmas preferem estabelecer preços na sua própria moeda; iii) medidas de intensidade de uso de insumos básicos na produção, que tendem a ter preços em USD; iv) medidas de volatilidade de câmbio; v) medidas da qualidade de uma moeda como hedge para variações no custo marginal da firma; e vi) o regime cambial do país exportador.

Entre outros resultados, Goldberg e Tille (2009) observam que transações de valor relativamente maior em uma dada indústria (nível 4 do sistema harmonizado) tendem a usar mais a moeda local. Os autores interpretam esse resultado como evidência de que o poder de barganha dos importadores é um dos determinantes na escolha da moeda de invoice.

Em artigo em versão ainda preliminar, Devereux, Dong e Tomlin $(2013)^{8}$ também utilizam dados alfandegários de importação do Canadá, no período 2002-2008, para calcular coeficientes de pass-through em especificação similar à de Gopinath et al (2010). Como proxy dos preços de importação, utilizam valores unitários. Os resultados preliminares confirmam a forte influência da moeda de invoice nos coeficientes de pass-through.

Friberg e Wilander (2007) ${ }^{9}$ analisam a escolha da moeda de invoice por firmas exportadoras da Suécia com base em um questionário respondido por aproximadamente 250 firmas em 2006. Os resultados obtidos a partir dos questionários são especialmente interessantes, dado que podem indicar aspectos da escolha de moeda de invoice que não são evidentes nos microdados exportação e importação utilizados em outros artigos.

Com base nas respostas ao questionário, Friberg e Wilander (2007) reportam que as moedas de invoice, de precificação, e de pagamento são em geral as mesmas para as firmas exportadoras. Quanto à moeda escolhida, a moeda do país importador é a mais usada quando o destino das exportações é a União Europeia (EUR) ou os Estados Unidos (USD); para outros destinos é mais comum o uso de uma moeda veículo.

${ }^{8}$ Devereux, Dong e Tomlin (2013), "Exchange Rate Pass-Through, Currency Invoicing and Trade Partners".

${ }^{9}$ Friberg e Wilander (2007), "Price Setting Transactions and the Role of Denominating Currency in FX Markets". 
As questões relacionadas aos determinantes da escolha da moeda de invoice têm interpretação mais ambígua. Ainda assim, os autores reportam as seguintes respostas típicas (entre outras):

na escolha da moeda de invoice, a negociação com o importador é importante;

transações com valor elevado e exportações para grandes mercados tendem a utilizar a moeda do importador.

Os dois resultados acima favorecem modelos em que a escolha da moeda de invoice é fruto de um processo de barganha entre o exportador e importador, e onde ambos têm preferência por sua própria moeda.

Por outro lado, o questionário indica que a moeda de invoice utilizada por firmas competidoras não é um fator importante na escolha da moeda de invoice pela própria firma. Esse resultado contrasta com uma das justificativas dadas para o elevado uso do dólar no comércio de commodities - fatores de "coalescência", conforme o artigo de Goldberg e Tille (2009). Ainda segundo o questionário, a trajetória que a firma antecipa para a taxa de câmbio é pouco relevante para a escolha da moeda de invoice, i.e. a escolha não é feita em função de uma esperada valorização ou desvalorização da taxa de câmbio.

Fitzgerald e Haller (2014) utilizam microdados da pesquisa de preços ao produtor da Irlanda no período 1995-2005 para estudar o pricing-to-market nas exportações irlandesas. Na pesquisa de preços, as firmas reportam mensalmente os preços de um determinado produto em vendas no mercado interno e no mercado externo separadamente. Para as vendas no mercado externo, as firmas também indicam a moeda de invoice utilizada.

Os dados de Fitzgerald e Haller (2014) permitem controlar os componentes de custo marginal que são comuns aos bens vendidos no mercado interno e externo, de forma que conseguem identificar mais diretamente as variações de mark-up nas vendas da firma. Para as exportações realizadas na moeda do importador (no caso, a libra esterlina para as exportações para o Reino Unido), os autores observam que o mark-up nas vendas para o mercado externo variam um para um com variações no câmbio (euro-libra esterlina). Os autores também reportam que, dada a moeda de invoice, este comportamento é observado em setores variados e em firmas com características diferentes. 
Por último, Chatterjee, Dix-Carneiro e Vichyanond (2011) utilizam microdados do Siscomex no período 1997-2006 para estudar o comportamento, no Brasil, de firmas exportadoras multiprodutos. Entre outras resultados, os autores encontram um coeficiente de pass-through da taxa de câmbio real para os preços de exportação na moeda do importador de aproximadamente $76 \%$. A abertura do coeficiente por setores da indústria apresenta alguma heterogeneidade, mas a maioria dos coeficientes se situa entre $65 \%$ e $85 \%$ (para os preços na moeda do importador). Os autores também observam que características da firmas (em particular, diversas medidas de produtividade) influenciam no pass-through de câmbio para os preços de exportação: firmas com maior receita, maiores salários, maior número de produtos exportados, e que empregam mão de obra mais qualificada têm pass-through menor para os preços na moeda do importador, em linha com os resultados encontrados por Berman et al (2012). 


\section{BASES DE DADOS E TABELAS DE CLASSIFICAÇÃO DE PRODUTOS}

Esta seção descreve as bases de dados e as tabelas de classificação utilizadas neste dissertação. Em particular, discute mais extensivamente o tratamento dado às informações do Siscomex Exportação, conforme sua disponibilidade no Banco Central do Brasil.

\subsection{SISCOMEX EXPORTAÇÃO}

O Siscomex Exportação é o sistema de registro administrativo de operações de exportação no Brasil. Salvo exceções, toda operação deve ser documentada por um Registro de Exportação (RE). Este estudo utiliza como fonte de informação a base de registros de exportação do Siscomex mantida pelo Banco Central do Brasil.

A base de dados mantida pelo Banco Central do Brasil contém registros para o período 1993-2012, período no qual esteve em operação o sistema de registro via SISBACEN. Em novembro de 2010 passou a operar um novo sistema, batizado de NOVOEX. Os dois sistemas foram operados em paralelo até janeiro de 2012, quando o sistema via SISBACEN deixou de aceitar novos registros de exportação. A base de dados do Banco Central não inclui as operações registradas via NOVOEX. Não é completa, portanto, para os anos de 2010 e 2011, que fazem parte do estudo.

Cada RE pode documentar a exportação de um ou mais produtos. Aqui entende-se por produto um conjunto de bens identificados pela mesma $\mathrm{NCM}^{10}$, código do Mercosul para a classificação de bens. Quando o RE inclui produtos de mais de uma NCM, cada NCM é registrada em um anexo próprio - os anexos representam, portanto, partes de uma mesma operação de exportação. A base de dados do Banco Central identifica separadamente cada um dos anexos de um registro de exportação, e este estudo trata cada anexo como uma operação isolada. Não explora, portanto, o fato de o anexo fazer parte ou não de uma operação com outras mercadorias. A seção 2.1.1.4 descreve a classificação NCM em maior detalhe.

Operações em que o valor total da mercadoria seja menor do que US\$ 50 mil, dentre outros casos específicos, podem ser registrados via Declaração Simplificada de Exportação (DSE). A DSE entrou em vigor em 1999, com o objetivo de incentivar a exportação por

\footnotetext{
${ }^{10}$ Nomenclatura Comum do Mercosul.
} 
pequenas empresas, oferecendo uma alternativa mais simples e mais barata ao Registro de Exportação. O limite inicial para registro da exportação via DSE foi de US\$ 10 mil, passando a US\$ 20 mil em 2006, e US\$ 50 mil em 2008. Em 2012, segundo dados da Receita Federal, as exportações registradas via DSE totalizaram US\$ 760 milhões, ou $0,3 \%$ do total das exportações em valor. A base de dados utilizada para este estudo não inclui estas operações.

\subsubsection{CAMPOS UTILIZADOS PARA O ESTUDO}

A tabela 1 lista os campos do registro de exportação que foram utilizados no estudo. $\mathrm{O}$ tratamento dado a alguns campos é discutido nas seções seguintes.

Tabela 1: Campos do Siscomex Exportação utilizados no estudo.

\begin{tabular}{|c|c|}
\hline Campo & Descrição \\
\hline RE-NUM-REG & Número do registro de exportação, seguido do número do anexo. \\
\hline RE-DT-INIC-REG & Data de início do registro no sistema. \\
\hline RE-ST-REG & $\begin{array}{l}\text { Status do registro. Utilizado apenas como filtro para eliminar registros } \\
\text { cancelados, ou registros de histórico. }\end{array}$ \\
\hline $\begin{array}{l}\text { RE-IND-CGC-CPF- } \\
\text { EXPORT }\end{array}$ & $\begin{array}{l}\text { Indica se o exportador é pessoa física ou jurídica. Utilizado apenas como filtro } \\
\text { para eliminar exportações realizadas por pessoas físicas. }\end{array}$ \\
\hline RE-CGC-CPF-EXPORT & CNPJ do exportador. \\
\hline $\begin{array}{l}\text { RE-COD-ENQUADRAM- } \\
\text { OPE }\end{array}$ & $\begin{array}{l}\text { Código de enquadramento da operação. Indica a natureza da operação. Mais de } \\
\text { um enquadramento pode ser atribuído à mesma operação. }\end{array}$ \\
\hline $\begin{array}{l}\text { RE-COD-PAIS-DESTINO- } \\
\text { FINAL }\end{array}$ & País de destino final. \\
\hline RE-COD-MOEDA & Código da moeda de denominação da operação. \\
\hline RE-COD-NBM-SH & Classificação da mercadoria segundo a NCM. \\
\hline RE-PESO-LIQ-KG & Peso líquido da mercadoria, em kg. \\
\hline $\begin{array}{l}\text { RE-PRECO-TOT-LOCAL- } \\
\text { EMBARQUE-USD }\end{array}$ & Preço total da mercadoria no local de embarque (equivalência em USD). \\
\hline
\end{tabular}




\subsubsection{Campos de data}

Na base do Siscomex Exportação há cinco campos de data associados a cada RE, representando diferentes etapas do processo de exportação. A data de criação do RE no Siscomex ${ }^{11}$ foi o campo adotado para representar a data da transação, por provavelmente ser mais próximo do momento em que a negociação entre exportador e importador foi realizada, e, portanto, mais próxima do momento em que preços e quantidades foram definidos.

Também contribui para esta escolha o fato de a data de criação do registro ser aquela que indica com maior precisão a taxa de conversão dos valores da operação em dólares americanos, conforme os registros do sistema.

\subsubsection{Campo indicativo do tipo de exportador, pessoa física ou jurídica}

Com base no campo RE-IND-CGC-CPF-EXPORT, foram descartadas as operações em que o exportador declarou-se como pessoa física. Amostra preliminar de 912 mil registros de exportação, coletada para o período 1995-2012, indicou que as operações realizadas por pessoa física representavam apenas $0,1 \%$ das operações em quantidade e mesmo percentual das operações na ponderação por valor.

\subsubsection{Campo de enquadramento da operação}

O enquadramento ${ }^{12}$ é um campo que define a natureza da operação de exportação. Ao contrário de outros campos, é possível atribuir mais de um enquadramento para cada registro de exportação. No estudo foram incluídos apenas os registros de exportação em que o enquadramento indicasse venda definitiva e produção dos bens no país. Assim, foram excluídas, entre outras,

as operações enquadradas como exportações temporárias;

· $\quad$ as exportações de material usado;

- a exportação de produto importado anteriormente, sem a agregação de modificações (operações de reexportação);

\footnotetext{
${ }^{11}$ Campo RE-DT-INIC-REG na tabela 1.

${ }^{12}$ Campo RE-COD-ENQUADRAM-OPE na tabela 1.
} 
exportações FICTA, em que o bem é entregue no Brasil.

A tabela 30 no anexo A lista os enquadramentos incluídos e excluídos neste estudo. Foram descartados os registros de exportação classificados em pelo menos um enquadramento da lista de enquadramentos excluídos.

O critério de exclusão de enquadramentos adotado neste estudo coincide apenas parcialmente com o critério utilizado pelo MDIC para a compilação das exportações na balança comercial. A quarta coluna da tabela 30 indica o critério adotada para compilação da balança comercial, como referência. A quinta coluna indica, para cada enquadramento, sua incidência em uma amostra preliminar de registros de exportação para o período 1995-2012.

Para os enquadramentos de maior incidência, os critérios utilizados na dissertação e na compilação da balança comercial pelo MDIC coincidem. As diferenças ocorrem em operações de caráter mais específico, como exportações temporárias, exportações sem expectativa de recebimento, e exportações para uso e consumo de bordo. No geral, o critério indicado pela tabela 30 implica a exclusão de aproximadamente $10 \%$ dos registros de exportação, em quantidade.

\subsubsection{Campo de classificação da mercadoria}

Nos registros do comércio internacional de bens, os produtos são em geral classificados segundo o padrão internacional conhecido como Sistema Harmonizado (SH), instituído em 1988. O SH enquadra o universo de mercadorias em cerca de 5.000 códigos diferentes, cada um contendo 6 dígitos. Os três códigos abaixo, por exemplo, são utilizados para o caso de guarda-chuvas, sombrinhas e guarda-sóis:

· 660110 Garden or Similar Umbrellas;

- 660191 Umbrellas, Having a Telescopic Shaft;

. 660199 Other Umbrellas and Sun Umbrellas.

É evidente que, mesmo no seu nível mais detalhado, existe espaço para variações significativas de qualidade entre produtos com mesma classificação.

Os países que adotam o SH devem seguir o sistema no nível de 6 dígitos, mas podem utilizar dígitos adicionais de acordo com o interesse administrativo ou estatístico. Os dados 
dos Estados Unidos utilizados por Gopinath et al (2010) e os dados da Nova Zelândia utilizados por Fabling e Sanderson (2013) utilizam sistemas de classificação com 10 dígitos.

A classificação de mercadorias no comércio exterior do Brasil é compatível com o SH, e recebe o nome de Nomenclatura Comum do Mercosul (NCM). A NCM utiliza 8 dígitos e, na sua última versão, possui cerca de 10.000 códigos. A primeira versão da NCM foi introduzida em 1996, em substituição à Nomenclatura Brasileira de Mercadorias (NBM). Seguindo as revisões do SH, a NCM passou por grandes revisões em 2002, 2007, e 2012. Mesmo no intervalo entre duas revisões, a classificação é alterada através da adição, extinção ou desmembramento de códigos.

Mudanças na classificação são um problema potencial para este estudo, uma vez que a NCM, em conjunto com a identidade da firma e o país de destino, é utilizada para identificar a mercadoria exportada. $\mathrm{O}$ desmembramento ou agrupamento de códigos altera a composição dos produtos classificáveis em cada NCM, e pode agravar as deficiências derivadas do uso do valor unitário como proxy dos preços de exportação - estratégia que é adotada nas seções 4 e 5 a seguir.

Uma alternativa para lidar com as revisões é a construção e uso de grupos mínimos de comparação: todos os códigos afetados por um desmembramento ou agrupamento são tratados como um único código para todo o período de estudo. Esta alternativa não foi adotada devido à dificuldade de identificar todas as revisões, em especial aquelas realizadas entre duas versões da NCM.

Na base de dados do Siscomex Exportação, a NCM do produto exportado é registrada no campo RE-COD-NBM-SH, conforme indicado na tabela 1.

\subsubsection{Campos de valor da mercadoria}

Há quatro campos de valor associados a cada anexo de RE na base de dados do Siscomex. O campo RE-PRECO-TOT-COND-VENDA e o campo RE-PRECO-TOT-CONDVENDA-USD registram o valor das mercadorias na sua condição de venda ${ }^{13}$. O primeiro registra o valor na moeda de invoice, e o segundo, o valor equivalente em dólares.

\footnotetext{
${ }^{13}$ A condição de venda é identificada pelo código Incoterm da operação de exportação.
} 
Dependendo da condição de venda, este valor pode incluir despesas de frete, seguro, e taxas diversas até o destino final dos bens.

Os campos RE-PRECO-TOT-LOCAL-EMBARQUE e RE-PRECO-TOT-LOCALEMBARQUE-USD registram o valor total das mercadorias no seu ponto de embarque e excluem, portanto, despesas adicionais de frete internacional e de seguro, bem como taxas para a importação dos bens no destino final. O primeiro campo registra o valor na moeda de invoice e o segundo, o valor equivalente em dólares. Teste realizado em amostra preliminar da base de dados indicou que, a menos de diferenças muito pequenas, os valores são consistentes com as taxas de câmbio na data de início do registro.

Todas as análises apresentadas nesta dissertação baseiam-se no campo referente ao valor das mercadorias no local de embarque, em dólares ${ }^{14}$. Os campos que se referem ao valor das mercadorias na condição de venda foram utilizados apenas para verificar a consistência dos valores registrados na base de dados.

\subsubsection{Campos de país de destino e de país do importador}

Existem dois campos de país nos registros do Siscomex Exportação. O campo RECOD-PAIS-DESTINO-FINAL correponde ao país de destino, e o campo RE-COD-PAISIMPORT, ao país do importador. Na amostra geral para o período 2002-2010, as operações em que os países de destino e do importador são iguais representam 87\% das exportações em quantidade de registros e $46 \%$ das exportações em valor.

Nas exportações de bens diferenciados para a União Europeia no período 2002-2010, as operações em que o país de destino e o país do importador são iguais representam $83 \%$ das exportações em quantidade de registros e $73 \%$ das exportações em valor.

Para os resultados descritivos na seção 3 e nas análises das seções 4 e 5, foi utilizado o campo referente ao país de destino da mercadoria. Seria desejável repetir as análises da seção 5 com a utilização do campo referente ao país do importador. No entanto, devido a limitações na extração dos microdados da base do Siscomex, este teste não pôde ser realizado.

${ }^{14} \mathrm{O}$ valor na moeda de invoice também poderia ser utilizado, mas, para as comparações realizadas na seção 3, exigiriam um passo adicional de conversão para uma moeda comum e, por este motivo, só foram utilizados para verificar a consistência das informações declaradas no registro de exportação. 
Vale ressaltar que o estudo preliminar de Devereux, Dong e Tomlin (2013) $)^{15}$ encontrou diferenças significativas na dinâmica de preços de importações canadenses em função do campo utilizado como indicador de origem da mercadoria.

\subsubsection{REGISTROS DE EXPORTAÇÃO E BALANÇA COMERCIAL}

Este estudo não segue necessariamente os critérios adotados para a construção da balança comercial do Ministério do Desenvolvimento, Indústria e Comércio Exterior (MDIC). Entre outras potenciais diferenças metodológicas,

só foram incluídas operações que exigem registro de exportação (RE);

- os critérios para a inclusão de enquadramentos é diferente daqueles utilizados pelo MDIC para a construção da balança comercial;

- não foram incluídos registros de pessoas físicas.

Dadas as diferenças, é interessante comparar os valores agregados de exportação compilados pelo MDIC com aqueles obtidos diretamente a partir dos registros do Siscomex mantidos no Banco Central do Brasil. A tabela 2 indica o valor total das exportações no período 2001-2010 para uma seleção de países da União Europeia, segundo os dados da balança comercial (MDIC) e segundo os registros de exportação na base de dados do Siscomex.

Com exceção de Holanda e Suécia, as diferenças são menores do que 5\%, o que sugere que os dados utilizados na dissertação são representativos do universo de transações utilizados para compor a balança comercial.

15 Devereux, Dong e Tomlin (2013), "Exchange Rate Pass-Through, Currency Invoicing and Trade Partners". 
Tabela 2: Exportação por país de destino - comparação entre total na amostra e total na balança comercial (MDIC).

\begin{tabular}{cccc}
\hline \multirow{2}{*}{ País } & \multicolumn{3}{c}{ 2001-2010 (total em USD bilhões) } \\
& $\begin{array}{c}\text { Agregação } \\
\text { Siscomex }\end{array}$ & $\begin{array}{c}\text { Balança } \\
\text { comercial } \\
\text { (MDIC) }\end{array}$ & Diferença \\
\hline Holanda & 58,1 & 64,9 & $11,8 \%$ \\
\hline Alemanha & 52,5 & 53,3 & $1,5 \%$ \\
\hline Itália & 31,8 & 32,3 & $1,5 \%$ \\
\hline Reino Unido & 27,9 & 28,4 & $1,6 \%$ \\
\hline Bélgica & 26,9 & 27,8 & $3,3 \%$ \\
\hline França & 25,4 & 26,3 & $3,9 \%$ \\
\hline Espanha & 23,6 & 24,3 & $3,2 \%$ \\
\hline Portugal & 11,2 & 11,5 & $2,2 \%$ \\
\hline Noruega & 4,8 & 4,9 & $1,4 \%$ \\
\hline Suécia & 3,9 & 4,1 & $5,1 \%$ \\
\hline Finlândia & 3,2 & 3,2 & $-0,1 \%$ \\
\hline Dinamarca & 2,0 & 2,0 & $4,0 \%$ \\
\hline
\end{tabular}

\subsection{CENSO DE CAPITAIS ESTRANGEIROS NO BRASIL}

O Censo de Capitais Estrangeiros é realizado pelo Banco Central do Brasil desde 1996 e mapeia, entre outros tipos de capital, o investimento estrangeiro direto em firmas brasileiras. As primeiras edições do censo foram realizadas quinquenalmente: 1996, com ano base 1995; 2001, com ano base 2000; e 2006, com ano base 2005; e 2011, com ano base 2010. A partir de 2010, o censo passou a ser realizado anualmente para empresas de grande porte e mantevese o censo quinquenal para um universo maior de declarantes ${ }^{16}$.

Para a dissertação, utilizou-se o resultado apurado pelo censo de 2010. Em particular, foi utilizado o registro relativo à presença de investimento direto no capital das firmas brasileiras. Nesta edição do censo, o investimento direto foi definido como a participação de

\footnotetext{
${ }^{16}$ Ver Banco Central do Brasil (2014).
} 
empresas não-residentes em $10 \%$ ou mais das ações com direito a voto, ou em $20 \%$ ou mais do capital total.

Os dados do censo foram vinculados aos dados do Siscomex com base nos 8 primeiros dígitos do CNPJ das firmas receptoras do capital.

\subsection{CLASSIFICAÇÃO POR FATOR AGREGADO}

A classificação dos produtos por fator agregado é elaborada pelo Ministério do Desenvolvimento Indústria e Comércio Exterior e separa os bens em três categorias ${ }^{17}$ :

- básicos - produtos em estado próximo ao natural, com grau baixo de processamento (e.g. grãos, carne in natura);

semimanufaturados - produtos industrializados em estágio intermediário de processamento (e.g. laminados de aço, celulose, açúcar em bruto);

- $\quad$ manufaturados - demais produtos industrializados, em estágio final de processamento.

Uma quarta categoria, “Transações Especiais" é residual e se aplica a casos específicos, como o fornecimento de mercadorias para consumo de bordo em embarcações e aeronaves, e bens em movimentação em função de mudança de domicílio.

A tabela completa relacionando cada NCM no nível de 8 dígitos a uma das quatro categorias acima está disponível em MDIC (2014b).

\subsection{CLASSIFICAÇÃO DE RAUCH}

Rauch (1999) propõe classificar os bens em três categorias distintas:

bens que são negociados em mercados organizados (e.g. cereais não processados, minério de ferro, petróleo bruto);

bens que não são negociados em mercados organizados, mas que possuem preços de referência (e.g. resinas plásticas, papéis e papelão, placas de aço diversas);

\footnotetext{
${ }^{17}$ A definição vem de MDIC (2014a).
} 
- bens diferenciados (e.g. artigos de cutelaria, motores elétricos e de combustão interna, chocolates).

Rauch propõe duas classificações, que denomina de "conservadora" e "liberal". A proposta de duas classificações derivou da dificuldade de categorizar alguns grupos de produto. Em comparação à classificação conservadora, a classificação liberal tende a classificar mais produtos como homogêneos ou com preços de referência.

A categorização proposta por Rauch é baseada na versão 2 do Standard International Trade Classification (SITC Rev 2), no nível de quatro dígitos. Para traduzir o SITC Rev 2 nas três versões da NCM utilizadas ao longo do período de análise, foram utilizadas tabelas de conversão do SITC Rev 2 para as versões 1996, 2002 e 2007 do Sistema Harmonizado (SH), construídas pela UN Stats ${ }^{18}$.

A tabela completa com a classificação proposta por Rauch, baseada no SITC Rev 2, pode ser encontrada em Haveman (2014), conforme indicação na página profissional de James E. Rauch ${ }^{19}$. As tabelas de conversão entre o SITC Rev 2 e as diversas versões do Sistema Harmonizado podem ser encontradas em UNStats (2014).

\footnotetext{
${ }^{18}$ A seção 2.1.1.4 apresenta mais detalhes sobre a relação entre a NCM e o SH.

${ }^{19}$ Ver http://econweb.ucsd.edu/ jrauch/research_international_trade.html.
} 


\section{MOEDAS DE INVOICE NAS EXPORTAÇÕES BRASILEIRAS}

Esta seção traça um perfil geral da participação de diversas moedas como moeda de invoice nas exportações brasileiras, com ênfase na participação do euro, dólar e real.

As seções 3.1, 3.2, e 3.3 utilizam uma amostra de $20 \%$ do universo de registros de exportação com data entre 1999 e 2010 . A amostra foi obtida selecionando todos os registros de exportação com dígito identificador terminado em um ou seis. Todos os anexos de um registro de exportação selecionado foram incorporados à amostra. Foram excluídos registros em que o exportador foi declarado como pessoa física.

A seleção de registros com base no último dígito identificador foi utilizada devido à dificuldade de implementar um esquema de seleção aleatória. A seleção do total dos registros também não foi possível, em função do elevado volume de dados.

Após a exclusão de enquadramentos segundo as regras descritas na seção2.1.1.3, o esquema acima resultou na seleção de 9,7 milhões de operações de exportação ${ }^{20}$. Também foi removida uma pequena quantidade de registros com dados inconsistentes (da ordem de alguns milhares).

Depois de traçar o perfil geral das moedas de invoice nas exportações brasileiras nas seções 3.1 a 3.3, as seções 3.4 a 3.7 buscam caracterizar o uso do euro e do dólar nas exportações para a União Europeia. Para isso, foi selecionada a totalidade dos registros de exportação de bens diferenciados, com data de início entre 2001 e 2011, em que o país de destino pertencesse às principais economias da União Europeia. Com a exclusão de registros em que o exportador foi declarado como pessoa física, e a exclusão de enquadramentos segundo as regras descritas na seção 2.1.1.3, a amostra manteve 5,8 milhões de registros. Também foi removida uma pequena quantidade de registros com dados inconsistentes (da ordem de alguns milhares).

20 Cada operação equivale a um anexo de registro de exportação, conforme descrito na seção 2.1. Os registros excluídos pelo critério de enquadramento representam cerca de $10 \%$ do total de registros originais. 


\subsection{DESTINO DAS EXPORTAÇÕES E MOEDAS DE PAGAMENTOS}

A tabela 3 indica, para o período 1999-2010, a participação do dólar, do euro e do real como moedas de pagamento para diversos agrupamentos de países, em função do valor das exportações. A tabela 4 apresenta as participações ponderadas pela quantidade de operações ${ }^{21}$.

Tabela 3: Moedas de pagamento na exportação, por bloco de destino - participação em valor das exportações.

\begin{tabular}{lccccc}
\hline Bloco & $\begin{array}{c}\% \text { no total da } \\
\text { amostra }\end{array}$ & USD & EUR & BRL & $\begin{array}{c}\text { Outras } \\
\text { moedas }\end{array}$ \\
\hline União Européia & $24 \%$ & $87 \%$ & $12 \%$ & $0 \%$ & $1 \%$ \\
\hline NAFTA & $21 \%$ & $99 \%$ & $0 \%$ & $0 \%$ & $0 \%$ \\
\hline Ásia (exclusive Oriente Médio) & $19 \%$ & $99 \%$ & $1 \%$ & $0 \%$ & $0 \%$ \\
\hline Mercosul & $11 \%$ & $98 \%$ & $0 \%$ & $2 \%$ & $0 \%$ \\
\hline América Do Sul (exclusive Mercosul) & $8 \%$ & $100 \%$ & $0 \%$ & $0 \%$ & $0 \%$ \\
\hline África (exclusive Oriente Médio) & $5 \%$ & $96 \%$ & $3 \%$ & $0 \%$ & $1 \%$ \\
\hline Oriente Médio & $4 \%$ & $95 \%$ & $5 \%$ & $0 \%$ & $0 \%$ \\
\hline Europa (exclusive União Européia) & $4 \%$ & $96 \%$ & $4 \%$ & $0 \%$ & $0 \%$ \\
\hline Caribe e América Central & $4 \%$ & $97 \%$ & $2 \%$ & $0 \%$ & $0 \%$ \\
\hline Oceania & $0 \%$ & $90 \%$ & $2 \%$ & $0 \%$ & $8 \%$ \\
\hline Outros & $0 \%$ & $98 \%$ & $2 \%$ & $0 \%$ & $0 \%$ \\
\hline Total & $\mathbf{1 0 0 \%}$ & $\mathbf{9 6 \%}$ & $\mathbf{4 \%}$ & $\mathbf{0 \%}$ & $\mathbf{1 \%}$ \\
\hline
\end{tabular}

21 Aqui, e no restante da seção 3, entende-se por "operação" cada um dos anexos de um registro de exportação. Assim, uma exportação que resulte em apenas um registro de exportação, mas envolva bens de duas NCMs, é tratada nesta seção como duas operações diferentes. Para detalhes, ver seção 2.1. 
Tabela 4: Moedas de pagamento na exportação, por bloco de destino - participação em quantidade de operações.

\begin{tabular}{lccccc}
\hline Bloco & $\begin{array}{c}\% \text { no total da } \\
\text { amostra }\end{array}$ & USD & EUR & BRL & $\begin{array}{c}\text { Outras } \\
\text { moedas }\end{array}$ \\
\hline União Européia & $13 \%$ & $68 \%$ & $29 \%$ & $0 \%$ & $3 \%$ \\
\hline NAFTA & $17 \%$ & $100 \%$ & $0 \%$ & $0 \%$ & $0 \%$ \\
\hline Ásia (exclusive Oriente Médio) & $5 \%$ & $95 \%$ & $4 \%$ & $0 \%$ & $0 \%$ \\
\hline Mercosul & $32 \%$ & $75 \%$ & $0 \%$ & $24 \%$ & $0 \%$ \\
\hline América Do Sul (exclusive Mercosul) & $17 \%$ & $99 \%$ & $0 \%$ & $1 \%$ & $0 \%$ \\
\hline África (exclusive Oriente Médio) & $6 \%$ & $92 \%$ & $8 \%$ & $0 \%$ & $0 \%$ \\
\hline Oriente Médio & $2 \%$ & $96 \%$ & $3 \%$ & $0 \%$ & $0 \%$ \\
\hline Europa (exclusive União Européia) & $2 \%$ & $80 \%$ & $19 \%$ & $0 \%$ & $1 \%$ \\
\hline Caribe e América Central & $4 \%$ & $98 \%$ & $2 \%$ & $0 \%$ & $0 \%$ \\
\hline Oceania & $1 \%$ & $85 \%$ & $1 \%$ & $0 \%$ & $13 \%$ \\
\hline Outros & $0 \%$ & $96 \%$ & $4 \%$ & $0 \%$ & $0 \%$ \\
\hline Total & $\mathbf{1 0 0} \%$ & $\mathbf{8 6 \%}$ & $\mathbf{5 \%}$ & $\mathbf{8 \%}$ & $\mathbf{1 \%}$ \\
\hline
\end{tabular}

Nas duas tabelas acima fica evidente a dominância do dólar como moeda de pagamento das exportações brasileiras, com $96 \%$ das exportações em valor. Pelo mesmo critério, o euro e o real têm participações de $4 \%$ e $0,3 \%$ das operações, respectivamente.

A comparação entre as participações em valor e em quantidade indica, por outro lado, que o valor médio das exportações em real é muito inferior ao valor médio das exportações em dólar e euro. De fato, na amostra acima, os valores médios das exportações são US\$ 29,9 mil, US\$19,6 mil e US\$ 0,8 mil para o dólar, o euro e o real, respectivamente.

A dominância do dólar americano não é uniforme entre os destinos das exportações brasileiras. No comércio com a União Europeia o euro tem participação relevante. O mesmo vale para o real no comércio com o Mercosul, ainda que, em valor, a participação da moeda seja reduzida - apenas $2 \%$. Em quantidade, o real é a moeda de invoice em $24 \%$ das exportações para o bloco. 
Da mesma forma, os blocos listados nas tabelas 3 e 4 não são necessariamente homogêneos internamente, como pode ser observado nas tabelas 5 e 6 - a primeira com países do Mercosul e Bolívia, e a segunda com países em que o euro tem participação relevante entre as moedas de invoice.

Tabela 5: Moedas de pagamento na exportação - países do Mercosul e Bolívia.

\begin{tabular}{c|ccc|ccc}
\hline & \multicolumn{3}{|c}{ Participação em valor } & \multicolumn{3}{c}{ Participação em quantidade } \\
País & $\begin{array}{c}\% \text { no total da } \\
\text { amostra }\end{array}$ & USD & BRL & $\begin{array}{c}\% \text { no total da } \\
\text { amostra }\end{array}$ & USD & BRL \\
\hline Argentina & $9 \%$ & $99 \%$ & $1 \%$ & $17 \%$ & $99 \%$ & $1 \%$ \\
\hline Paraguai & $1 \%$ & $89 \%$ & $11 \%$ & $8 \%$ & $55 \%$ & $45 \%$ \\
\hline Uruguai & $1 \%$ & $98 \%$ & $2 \%$ & $8 \%$ & $42 \%$ & $58 \%$ \\
\hline Bolívia & $1 \%$ & $98 \%$ & $1 \%$ & $2 \%$ & $93 \%$ & $7 \%$ \\
\hline
\end{tabular}

Na tabela 5 é interessante notar a baixa participação do real no comércio com a Argentina, tanto em termos de quantidade quanto em termos de valor. Paraguai e Uruguai apresentam participação elevada do real em termos de quantidade de operações, mas os valores médios são baixos - US\$ 1 mil e US\$ 0,1 mil, respectivamente, ante US\$ 19 mil nas operações em real com a Argentina. A grande quantidade de operações de pequeno valor em real pode indicar algum efeito de fronteira na determinação da moeda de pagamento no comércio com estes países. 
Tabela 6: Moedas de pagamento na exportação - países com participação relevante do euro entre as moedas de pagamento.

\begin{tabular}{|c|c|c|c|c|c|c|}
\hline \multirow{2}{*}{ País } & \multicolumn{3}{|c|}{ Participação em valor } & \multicolumn{3}{|c|}{ Participação em quantidade } \\
\hline & $\begin{array}{c}\% \text { no total da } \\
\text { amostra }\end{array}$ & USD & EUR & $\begin{array}{l}\% \text { no total da } \\
\text { amostra }\end{array}$ & USD & EUR \\
\hline Holanda & $5 \%$ & $90 \%$ & $10 \%$ & $1 \%$ & $73 \%$ & $26 \%$ \\
\hline Alemanha & $4 \%$ & $79 \%$ & $20 \%$ & $3 \%$ & $55 \%$ & $43 \%$ \\
\hline Itália & $3 \%$ & $87 \%$ & $13 \%$ & $2 \%$ & $68 \%$ & $31 \%$ \\
\hline Bélgica & $2 \%$ & $91 \%$ & $8 \%$ & $1 \%$ & $70 \%$ & $28 \%$ \\
\hline Reino Unido & $2 \%$ & $90 \%$ & $3 \%$ & $2 \%$ & $80 \%$ & $6 \%$ \\
\hline França & $2 \%$ & $85 \%$ & $14 \%$ & $2 \%$ & $73 \%$ & $26 \%$ \\
\hline Espanha & $2 \%$ & $89 \%$ & $11 \%$ & $1 \%$ & $69 \%$ & $31 \%$ \\
\hline Índia & $1 \%$ & $99 \%$ & $1 \%$ & $1 \%$ & $89 \%$ & $10 \%$ \\
\hline Irã & $1 \%$ & $84 \%$ & $16 \%$ & $0 \%$ & $73 \%$ & $27 \%$ \\
\hline África do Sul & $1 \%$ & $93 \%$ & $7 \%$ & $2 \%$ & $81 \%$ & $19 \%$ \\
\hline Portugal & $1 \%$ & $87 \%$ & $13 \%$ & $1 \%$ & $51 \%$ & $49 \%$ \\
\hline Suíça & $1 \%$ & $95 \%$ & $4 \%$ & $0 \%$ & $77 \%$ & $19 \%$ \\
\hline Turquia & $0 \%$ & $88 \%$ & $11 \%$ & $1 \%$ & $56 \%$ & $44 \%$ \\
\hline Noruega & $0 \%$ & $97 \%$ & $3 \%$ & $0 \%$ & $84 \%$ & $14 \%$ \\
\hline Suécia & $0 \%$ & $81 \%$ & $16 \%$ & $0 \%$ & $73 \%$ & $23 \%$ \\
\hline Finlândia & $0 \%$ & $94 \%$ & $6 \%$ & $0 \%$ & $84 \%$ & $16 \%$ \\
\hline Romênia & $0 \%$ & $97 \%$ & $3 \%$ & $0 \%$ & $91 \%$ & $9 \%$ \\
\hline Dinamarca & $0 \%$ & $94 \%$ & $5 \%$ & $0 \%$ & $79 \%$ & $18 \%$ \\
\hline
\end{tabular}

A tabela 6 indica que o uso do euro como moeda de pagamento não é restrito às exportações para os países da união monetária europeia. Exportações para o Reino Unido, Suíça, Noruega, Suécia, Turquia e Romênia, na Europa, e para o Irã, Índia e África do Sul utilizam a moeda, ainda que de forma limitada. 
Dentro da Zona do Euro o peso da moeda comum nas exportações brasileiras, em valor, varia de $20 \%$ nas exportações para a Alemanha, a $11 \%$ nas exportações para a Espanha e $8 \%$ nas exportações para a Bélgica. Em quantidade, atinge 49\% em Portugal e 43\% na Alemanha, ante $31 \%$ na Espanha e $28 \%$ na Bélgica.

A elevada participação relativa da Holanda no destino das exportações sugere cautela na interpretação dos dados desagregados por país, em particular para os países da União Europeia $^{22}$. O país de destino pode indicar apenas o ponto de entrada da mercadoria na união aduaneira, não necessariamente o país onde será definitivamente consumido.

Por fim, as figuras 1, 2 e 3 abaixo indicam a evolução do real e do euro nas exportações para os países do Mercosul e da União Europeia no período 1999-2010.

Nas exportações para o Mercosul não há tendência clara na evolução do real como moeda de pagamento, embora a série da participação em valor apresente algum crescimento nos dois últimos anos do período. A figura 2 sugere que esse crescimento está relacionado ao comportamento das exportações para a Argentina, que respondem, na amostra, por $81 \%$ das exportações para o bloco.

Nas exportações para a União Europeia é possível observar o avanço do euro como moeda de pagamento nos primeiros anos após a adoção da moeda única, tanto em termos de quantidade quanto em termos de valor. Após 2006 a participação em valor mantém-se próxima a $14 \%$, enquanto a participação em quantidade continua crescendo e atinge $46 \%$ em 2010.

As estatísticas acima indicam um padrão muito diferente daquele descrito para o comércio exterior dos Estados Unidos e Nova Zelândia nos artigos de Gopinath et al (2010) e de Fabling e Sanderson (2013). Gopinath et al (2010) indicam que quase a totalidade dos produtos exportados pelos Estados Unidos utiliza a moeda própria (o dólar) como moeda de pagamento, mesmo nas exportações que têm a Zona do Euro como destino. O dólar também predomina nas importações americanas, mas a participação da moeda do país exportador é relevante em alguns casos - 40\% nas importações com origem na Alemanha, $21 \%$ nas importações com origem no Japão, e 16\% nas importações com origem no Reino Unido.

\footnotetext{
${ }^{22}$ Em 2012, o PIB holandês em dólar equivalia a cerca de $20 \%$ do PIB alemão.
} 
Nas exportações da Nova Zelândia, Fabling e Sanderson (2013) encontram participação relevante do dólar neozelandês (NZD) entre as moedas de pagamento para todos os destinos. Na ponderação por valor, o NZD é a moeda de pagamento em $56 \%$ das exportações em que a Austrália é o país de destino, em 46\% das exportações em que o destino é o Japão, e em 52\% das exportações em que o destino é a Zona do Euro. A participação do NZD é relevante mesmo nas exportações para os Estados Unidos (37\%, na ponderação em valor).

Assim, enquanto a moeda do país produtor apresenta participação elevada nas exportações com origem nos Estados Unidos, Nova Zelândia, Zona do Euro, e Japão, o uso do real nas exportações brasileiras é limitado, e pode ser caracterizado por operações de baixo valor médio no âmbito do comércio com países fronteiriços.

Além do dólar, que predomina no conjunto das exportações, o euro também apresenta participação relevante nas exportações do Brasil para a União Europeia. Assim, enquanto parte significativa da literatura recente de currency choice discute a escolha entre a moeda do país importador (local curreny pricing, LCP) e a moeda do país produtor (producer currency pricing, PCP), as exportações brasileiras utilizam essencialmente uma moeda veículo (USD) ou, nas exportações para a Zona do Euro, a moeda do importador ${ }^{23}$. O padrão apresentado pelas exportações brasileiras é similar ao de economias menores, de acordo com os dados apresentados por Goldberg e Tille (2005), entre eles a Coréia do Sul, a Tailândia e países do Leste Europeu.

${ }^{23}$ Além do uso do BRL nas exportações para o Mercosul e Bolívia, há dois outros casos excepcionais: o uso do dólar australiano nas exportações para a Austrália e o uso da libra esterlina nas exportações para o Reino Unido. 


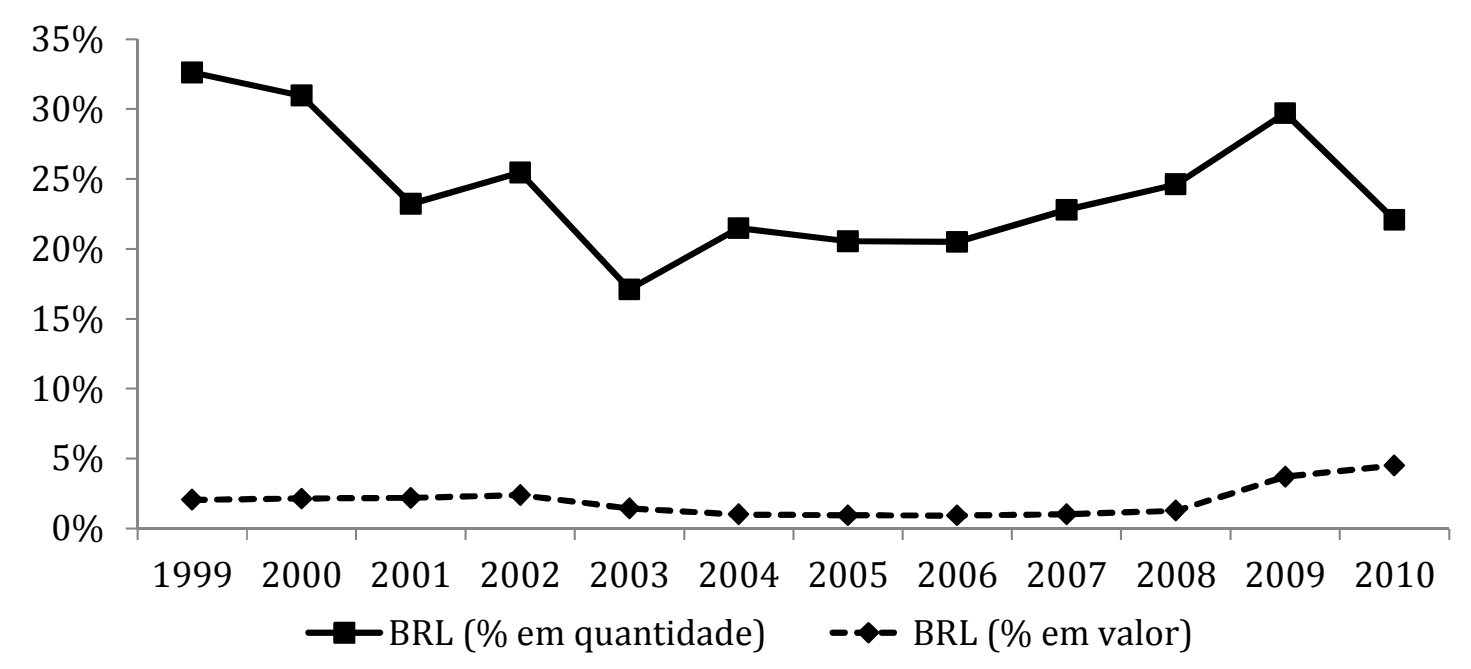

Figura 1: Participação do BRL nas exportações brasileiras para o Mercosul.

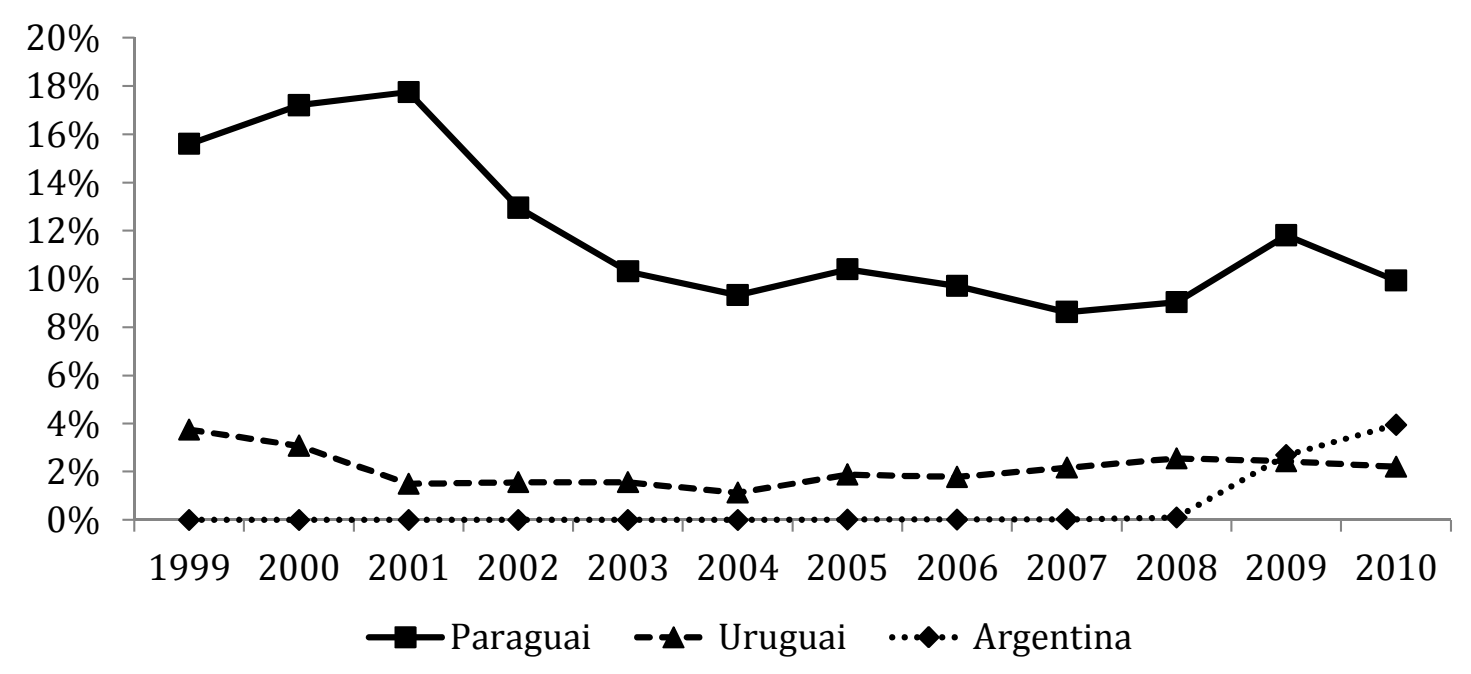

Figura 2: BRL nas exportações brasileiras para o Mercosul - participação em valor, por país. 


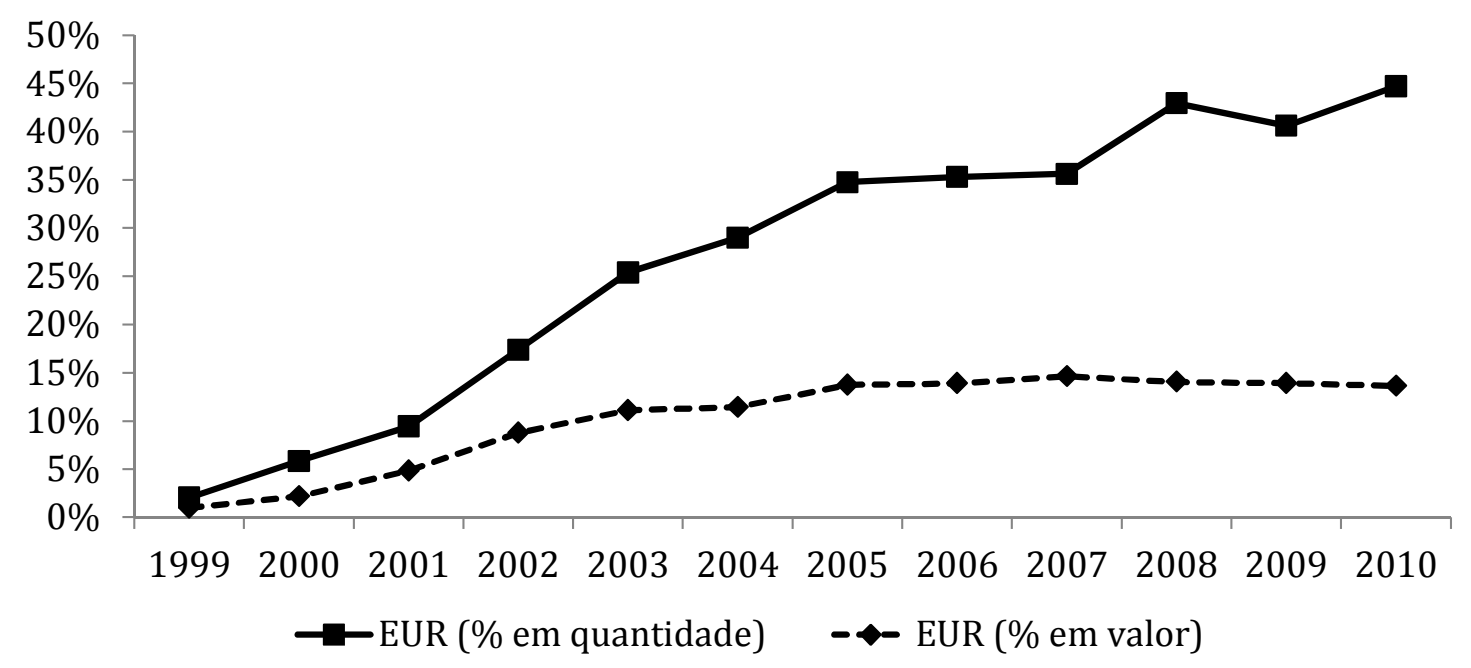

Figura 3: EUR nas exportações brasileiras para a União Europeia.

\subsection{FATOR AGREGADO E MOEDAS DE PAGAMENTO}

A tabela 7 indica, para o período 1999-2010, a participação do dólar, do euro e do real como moedas de invoice para produtos básicos, semimanufaturados e manufaturados, em função do valor das exportações. A tabela 8 apresenta as participações ponderadas pela quantidade de operações.

Tabela 7: Moedas de pagamento na exportação, por fator agregado - participação em valor.

\begin{tabular}{lccccc}
\hline Fator agregado & $\begin{array}{c}\% \text { no total da } \\
\text { amostra }\end{array}$ & USD & EUR & BRL & $\begin{array}{c}\text { Outras } \\
\text { moedas }\end{array}$ \\
\hline Básicos & $35 \%$ & $98 \%$ & $2 \%$ & $0 \%$ & $0 \%$ \\
\hline Semimanufaturados & $14 \%$ & $98 \%$ & $2 \%$ & $0 \%$ & $0 \%$ \\
\hline Manufaturados & $50 \%$ & $93 \%$ & $6 \%$ & $0 \%$ & $1 \%$ \\
\hline
\end{tabular}


Tabela 8: Moedas de pagamento na exportação, por fator agregado - participação em quantidade de operações.

\begin{tabular}{lccccc}
\hline Fator agregado & $\begin{array}{c}\% \text { no total da } \\
\text { amostra }\end{array}$ & USD & EUR & BRL & $\begin{array}{c}\text { Outras } \\
\text { moedas }\end{array}$ \\
\hline Básicos & $7 \%$ & $92 \%$ & $6 \%$ & $1 \%$ & $0 \%$ \\
\hline Semimanufaturados & $2 \%$ & $93 \%$ & $6 \%$ & $1 \%$ & $0 \%$ \\
\hline Manufaturados & $90 \%$ & $86 \%$ & $5 \%$ & $9 \%$ & $1 \%$ \\
\hline
\end{tabular}

Dois padrões se destacam nas tabelas 7 e 8 . O primeiro é a predominância do USD nos três grupos de produto, com participação em valor superior a $90 \%$ em cada um. O segundo é a participação relativamente menor do USD na exportação de manufaturados, quando comparada à participação da mesma moeda na exportação de básicos e semimanufaturados.

A tendência sugerida nas tabelas 7 e 8 para a amostra ampla fica mais evidente na tabela 9, que desagrega as exportações que têm apenas a União Europeia como destino. Nas exportações de produtos básicos o EUR tem participação reduzida (3\% em valor, ante $97 \%$ do USD). Nas exportações de manufaturados, a participação do EUR sobe para $26 \%$, enquanto a participação do dólar cai para $72 \%$ do valor total das operações.

A tabela 10 faz o mesmo exercício, desta vez para as exportações que têm Argentina, Paraguai, Uruguai e Bolívia como destino. Ainda que o padrão seja similar, a característica mais marcante, neste caso, é a participação muito reduzida de produtos básicos e semimanufaturados na pauta de exportações. De fato, exportações de básicos e semimanufaturados em real representam, em valor, apenas $1,4 \%$ e $1 \%$ das operações com estes países, respectivamente.

O padrão sugerido pelas tabelas 7 a 10 é consistente com a literatura empírica de currency choice, que associam o uso do USD à exportação de produtos mais homogêneos. A seção a seguir explora mais diretamente a associação entre diferenciação dos produtos e moedas de invoice usando a classificação de produtos sugerida por Rauch (1999). 
Tabela 9: Moedas de pagamento na exportação para a União Europeia - participação por fator agregado.

\begin{tabular}{l|ccc|ccc}
\hline & \multicolumn{3}{c}{ Participação em valor } & \multicolumn{3}{c}{ Participação em quantidade } \\
Fator agregado & $\begin{array}{c}\% \text { no total do } \\
\text { bloco }\end{array}$ & USD & EUR & $\begin{array}{c}\% \text { no total do } \\
\text { bloco }\end{array}$ & USD & EUR \\
\hline Básicos & $49 \%$ & $97 \%$ & $3 \%$ & $19 \%$ & $83 \%$ & $16 \%$ \\
\hline Semimanufaturados & $14 \%$ & $93 \%$ & $7 \%$ & $6 \%$ & $82 \%$ & $17 \%$ \\
\hline Manufaturados & $38 \%$ & $72 \%$ & $26 \%$ & $76 \%$ & $62 \%$ & $35 \%$ \\
\hline
\end{tabular}

Tabela 10: Moedas de pagamento na exportação para Argentina, Paraguai, Uruguai e Bolívia - participação por fator agregado.

\begin{tabular}{l|ccc|ccc}
\hline \multirow{2}{*}{ Fator agregado } & \multicolumn{3}{|c}{ Participação em valor } & \multicolumn{3}{c}{ Participação em quantidade } \\
& $\begin{array}{c}\% \text { no total do } \\
\text { bloco }\end{array}$ & USD & BRL & $\begin{array}{c}\% \text { no total do } \\
\text { bloco }\end{array}$ & USD & BRL \\
\hline Básicos & $5 \%$ & $98 \%$ & $1 \%$ & $2 \%$ & $81 \%$ & $19 \%$ \\
\hline Semimanufaturados & $3 \%$ & $98 \%$ & $1 \%$ & $1 \%$ & $92 \%$ & $8 \%$ \\
\hline Manufaturados & $92 \%$ & $98 \%$ & $2 \%$ & $98 \%$ & $77 \%$ & $23 \%$ \\
\hline
\end{tabular}

\subsection{DIFERENCIAÇÃO DE BENS E MOEDAS DE PAGAMENTO}

A prevalência do dólar nas exportações de produtos básicos é consistente com modelos teóricos e com resultados empíricos. Os resultados em Kamps (2006) e Goldberg e Tille (2005) sugerem que o uso do dólar está associado ao grau de diferenciação dos produtos: a exportação de produtos homogêneos tende a ser denominada em dólar, enquanto a exportação de produtos diferenciados tende a ser denominada em um número maior de moedas.

Além de Goldberg e Tille (2005) e Kamps (2006), Gopinath et al (2010) e Fabling e Sanderson (2013) utilizam a classificação proposta por Rauch (1999) para agrupar os produtos de acordo com o seu nível de diferenciação (ver detalhes na seção 2.4). As tabelas 11 e 12 indicam, para o período 1999-2010, a participação do dólar, do euro e do real como 
moedas de invoice para os três grupos definidos pela classificação de Rauch na sua versão liberal. O padrão observado nas duas tabelas é similar ao observado na seção 3.2 para o agrupamento por fator agregado: bens homogêneos tendem a utilizar mais o dólar.

Tabela 11 : Moedas de pagamento na exportação, de acordo com a classificação liberal de Rauch - participação em valor.

\begin{tabular}{lccccc}
\hline Classificação de Rauch & $\begin{array}{c}\% \text { no total da } \\
\text { amostra }\end{array}$ & USD & EUR & BRL & $\begin{array}{c}\text { Outras } \\
\text { moedas }\end{array}$ \\
\hline Bens homogêneos & $41 \%$ & $99 \%$ & $1 \%$ & $0 \%$ & $0 \%$ \\
\hline Bens com preços de referência & $20 \%$ & $94 \%$ & $5 \%$ & $0 \%$ & $1 \%$ \\
\hline Bens diferenciados & $39 \%$ & $92 \%$ & $6 \%$ & $0 \%$ & $1 \%$ \\
\hline
\end{tabular}

Tabela 12: Moedas de pagamento na exportação, de acordo com a classificação liberal de Rauch - participação em quantidade de operações.

\begin{tabular}{lccccc}
\hline Classificação de Rauch & $\begin{array}{c}\% \text { no total da } \\
\text { amostra }\end{array}$ & USD & EUR & BRL & $\begin{array}{c}\text { Outras } \\
\text { moedas }\end{array}$ \\
\hline Bens homogêneos & $4 \%$ & $98 \%$ & $1 \%$ & $1 \%$ & $0 \%$ \\
\hline Bens com preços de referência & $11 \%$ & $85 \%$ & $5 \%$ & $9 \%$ & $1 \%$ \\
\hline Bens diferenciados & $85 \%$ & $86 \%$ & $5 \%$ & $8 \%$ & $1 \%$ \\
\hline
\end{tabular}

As tabelas 13 e 14 repetem o exercício anterior, mas restringindo a amostra às exportações cujo destino seja a União Europeia. A tabela 13 utiliza a versão liberal da classificação de Rauch, enquanto a tabela 14 utiliza a versão conservadora. As tabelas deixam mais evidente o padrão sugerido pela amostra ampla: praticamente todas as exportações de bens homogêneos são realizadas em dólar, ante $69 \%$ das exportações de bens diferenciados (participação em valor na classificação liberal).

A tabela 15 desagrega as exportações cujo destino são o Mercosul e Bolívia segundo a classificação liberal de Rauch. O valor reduzido das exportações em real dificulta a avaliação dos resultados, mas, em quantidade de operações, também é possível observar o padrão geral sugerido pelas tabelas anteriores. 
Tabela 13 : Moedas de pagamento na exportação para a União Europeia, de acordo com a classificação liberal de Rauch.

\begin{tabular}{l|ccc|ccc}
\hline & \multicolumn{3}{|c}{ Participação em valor } & \multicolumn{3}{c}{ Participação em quantidade } \\
\hline Classificação de Rauch & $\begin{array}{c}\% \text { no total do } \\
\text { bloco }\end{array}$ & USD & EUR & $\begin{array}{c}\% \text { no total do } \\
\text { bloco }\end{array}$ & USD & EUR \\
\hline Bens homogêneos & $50 \%$ & $99 \%$ & $0 \%$ & $9 \%$ & $98 \%$ & $2 \%$ \\
\hline Bens com preços de referência & $23 \%$ & $81 \%$ & $17 \%$ & $16 \%$ & $72 \%$ & $25 \%$ \\
\hline Bens diferenciados & $27 \%$ & $69 \%$ & $29 \%$ & $75 \%$ & $63 \%$ & $34 \%$ \\
\hline
\end{tabular}

Tabela 14: Moedas de pagamento na exportação para a União Europeia, de acordo com a classificação conservadora de Rauch.

\begin{tabular}{|c|c|c|c|c|c|c|}
\hline \multirow{2}{*}{ Classificação de Rauch } & \multicolumn{3}{|c|}{ Participação em valor } & \multicolumn{3}{|c|}{ Participação em quantidade } \\
\hline & $\begin{array}{c}\% \text { no total do } \\
\text { bloco }\end{array}$ & USD & EUR & $\begin{array}{c}\% \text { no total do } \\
\text { bloco }\end{array}$ & USD & EUR \\
\hline Bens homogêneos & $57 \%$ & $99 \%$ & $1 \%$ & $12 \%$ & $97 \%$ & $3 \%$ \\
\hline Bens com preços de referência & $18 \%$ & $74 \%$ & $24 \%$ & $16 \%$ & $65 \%$ & $32 \%$ \\
\hline Bens diferenciados & $25 \%$ & $68 \%$ & $29 \%$ & $72 \%$ & $64 \%$ & $33 \%$ \\
\hline
\end{tabular}

Tabela 15: Moedas de pagamento na exportação para o Mercosul e Bolívia, de acordo com a classificação liberal de Rauch.

\begin{tabular}{|c|c|c|c|c|c|c|}
\hline \multirow{2}{*}{ Classificação de Rauch } & \multicolumn{3}{|c|}{ Participação em valor } & \multicolumn{3}{|c|}{ Participação em quantidade } \\
\hline & $\begin{array}{c}\% \text { no total do } \\
\text { bloco }\end{array}$ & USD & BRL & $\begin{array}{c}\% \text { no total do } \\
\text { bloco }\end{array}$ & USD & BRL \\
\hline Bens homogêneos & $9 \%$ & $99 \%$ & $1 \%$ & $2 \%$ & $90 \%$ & $10 \%$ \\
\hline Bens com preços de referência & $22 \%$ & $98 \%$ & $2 \%$ & $10 \%$ & $71 \%$ & $29 \%$ \\
\hline Bens diferenciados & $69 \%$ & $97 \%$ & $2 \%$ & $88 \%$ & $77 \%$ & $23 \%$ \\
\hline
\end{tabular}




\subsection{FIRMAS, PRODUTOS E MOEDAS}

Apesar de indicar um padrão geral em que a exportação de bens homogêneos tendem a utilizar mais o dólar, as tabelas 13 e 14 da seção 3.3 também mostram participação elevada do dólar como moeda de invoice na exportação de bens diferenciados. O objetivo desta seção é indicar em que medida o uso de uma ou outra moeda está associado ao produto exportado ou à firma exportadora, i.e. avaliar em que medida as firmas exportadoras utilizam somente uma única moeda nas suas exportações; e, por outro lado, em que medida as exportações de um dado produto $(\mathrm{NCM})$ utiliza somente uma única moeda invoice.

Ao contrário das seções anteriores, esta seção restringe a análise às exportações de bens diferenciados cujo destino tenha sido a União Europeia, caso em que é possível observar maior heterogeneidade no uso de moedas de invoice. Nos resultados apresentados a seguir foi compilado o universo das operações de exportação no período 2001-2011. Como a figura 3 sugere que o uso do euro nas exportações aumentou ao longo do período, os resultados são apresentados em base anual.

A figura 4 mostra para cada ano no período 2001-2011 o percentual de firmas (definidas pelos 8 primeiros dígitos do CNPJ) que exportaram predominantemente em dólar, em euro, em dólar e euro (EUR \& USD), ou que seguiram outros padrões (e.g. utilizaram o euro e o franco suíço). A predominância foi definida segundo dois critérios: i) mais de $90 \%$ das operações (em quantidade) realizadas na moeda; ou ii) mais de $90 \%$ das operações (em valor) realizadas na moeda. O padrão "EUR \& USD" foi definido como aquele em que o euro e o dólar somadas predominam, mas nenhuma das duas moedas predomina isoladamente. Em cada ano, só foram consideradas as firmas que realizaram pelo menos duas operações de exportação, o que elimina $17 \%$ das firmas. A figura 4 mostra as curvas obtidas para o critério de predominância em valor. As curvas para o critério de predominância em quantidade são muito similares. Também foi testada a restrição a produtos com pelo menos quatro operações de exportações no ano, com resultados também similares.

As figuras 5 e 6 mostram, para cada ano, o percentual dos produtos ${ }^{24}$ exportados predominantemente em dólar, em euro, em dólar e euro (EUR \& USD), ou em outras combinações. Em cada ano, só foram considerados os produtos com pelo menos duas

\footnotetext{
${ }^{24}$ Neste caso, o produto é definido pelo código NCM com 8 dígitos.
} 
operações de exportação, o que elimina $17 \%$ da amostra total. A figura 5 segue o critério de predominância em quantidade e a figura 6, o critério de predominância em valor. A restrição a produtos com pelo menos quatro operações de exportação no ano produz resultados similares.

Por último, a figura 7 mostra para cada ano no período 2001-2011 o percentual dos pares firma-produto exportados predominantemente em dólar, em euro, em dólar e euro (EUR \& USD), ou em outras combinações. Em cada ano só foram considerados os pares que ocorreram pelo menos duas vezes, o que elimina $41 \%$ das observações. A figura 7 mostra as curvas obtidas apenas para o critério de predominância em valor. As curvas para o critério de predominância em quantidade são similares. Também foi testada a restrição a produtos com pelo menos quatro operações de exportações no ano, com resultados semelhantes.

A evolução indicada nas três figuras depende em alguma medida da base temporal em que os percentuais são calculados e da exclusão de firmas ou produtos com baixa ocorrência em cada período. Quanto mais longa a base temporal, menor é a proporção de firmas que exportam em apenas uma moeda. O mesmo ocorre caso se eleve o número mínimo de operações por firma ou produto em cada período. Ainda assim, a tendência indicada pelas figuras 4 a 7 abaixo não muda de forma significativa.

Em geral, é possível identificar os seguintes padrões para as firmas no período:

- a proporção de firmas que exportam predominantemente em USD caiu ao longo da década após a introdução do EUR;

na direção contrária, a proporção de firmas que exportam predominantemente em EUR aumentou.

Em relação aos produtos, definidos por sua classificação na NCM (8 dígitos), os padrões são parecidos:

a proporção de produtos exportados predominantemente em USD caiu ao longo da década;

na direção contrária, a proporção de produtos exportados predominantemente em EUR aumentou.

Nos dois casos, parece existir alguma estabilização ou mesmo reversão na tendência de queda na participação das firmas e produtos exportados exclusivamente em USD a partir de 2009. 
A figura 7 segue mais de perto a definição de mercadoria na forma como é utilizada nas seções 4 e 5, dada por um trio NCM-Firma-Destino. Também neste caso é possível observar a tendência de queda na participação das mercadorias exportadas predominantemente em USD, e o crescimento da participação das exportadas predominantemente em EUR.

Apesar das ressalvas quanto à sensibilidade dos resultados à escolha da base temporal e à exclusão de firmas e produtos com poucas operações no período, a comparação entre a figura 5 e 6, por um lado, e as figuras 4 e 7 sugere que a escolha da moeda de invoice na exportação está mais associado à firma do que ao produto exportado (NCM). Mesmo no critério de predominância em valor, 33\% dos produtos em 2011 foram exportados nas duas moedas.

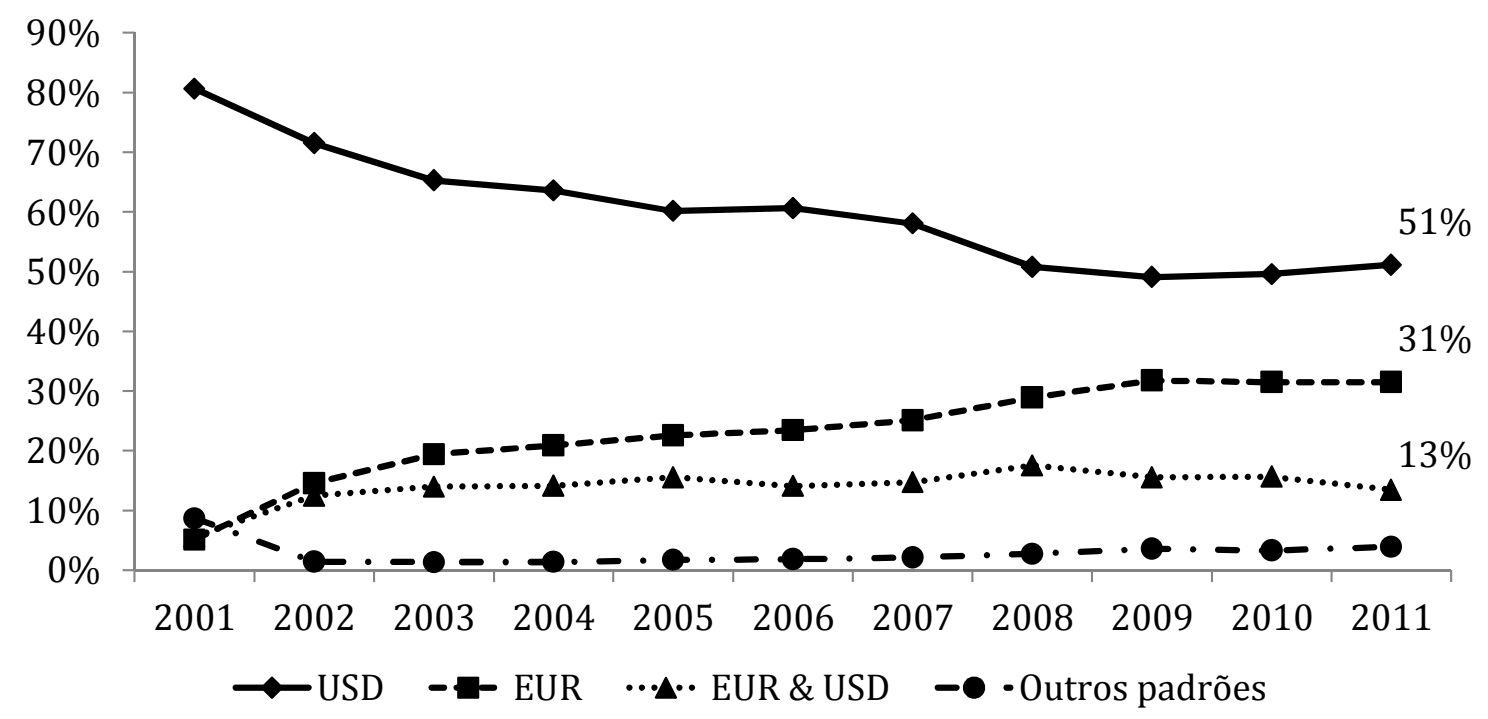

Figura 4: Moedas de pagamento por firma (CNPJ 8 dígitos) - predominância por valor. 


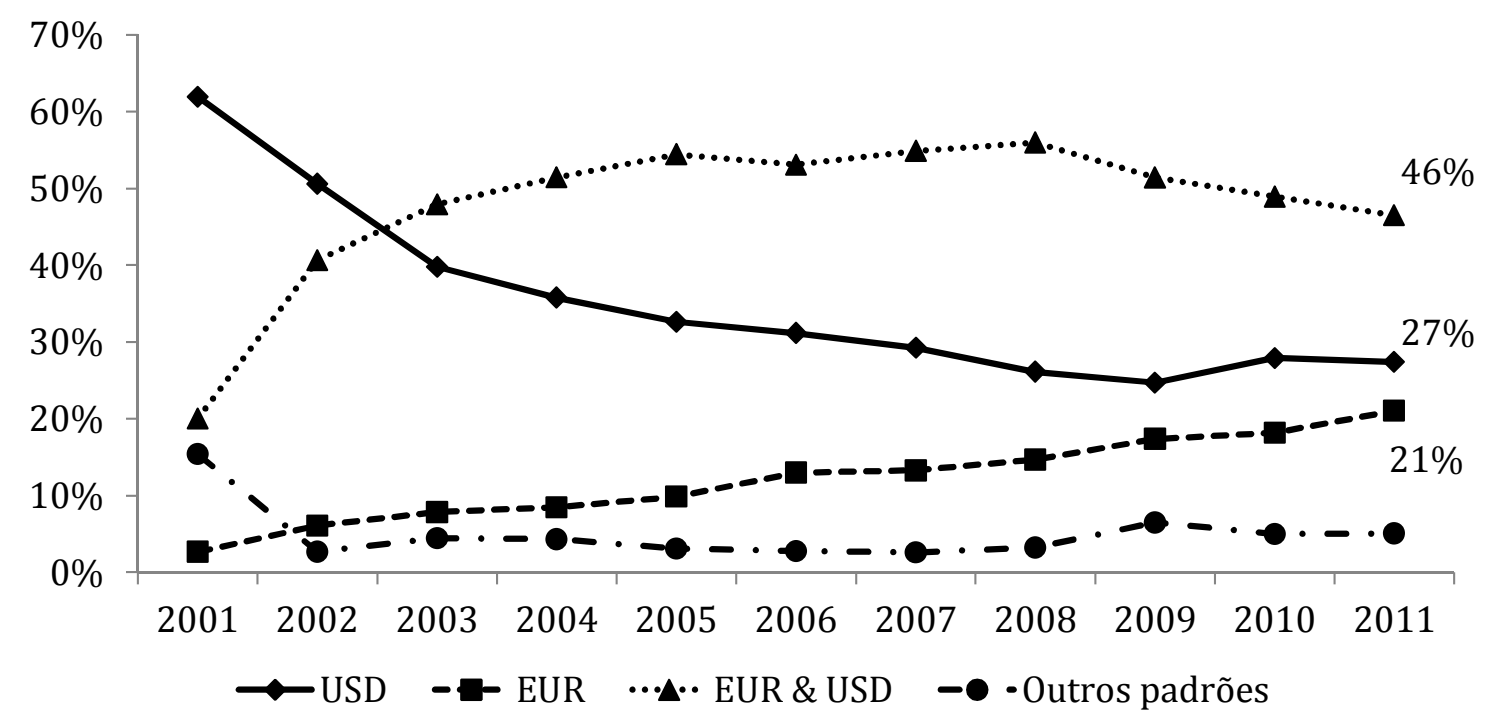

Figura 5: Moedas de pagamento por NCM (8 dígitos) - predominância por quantidade.

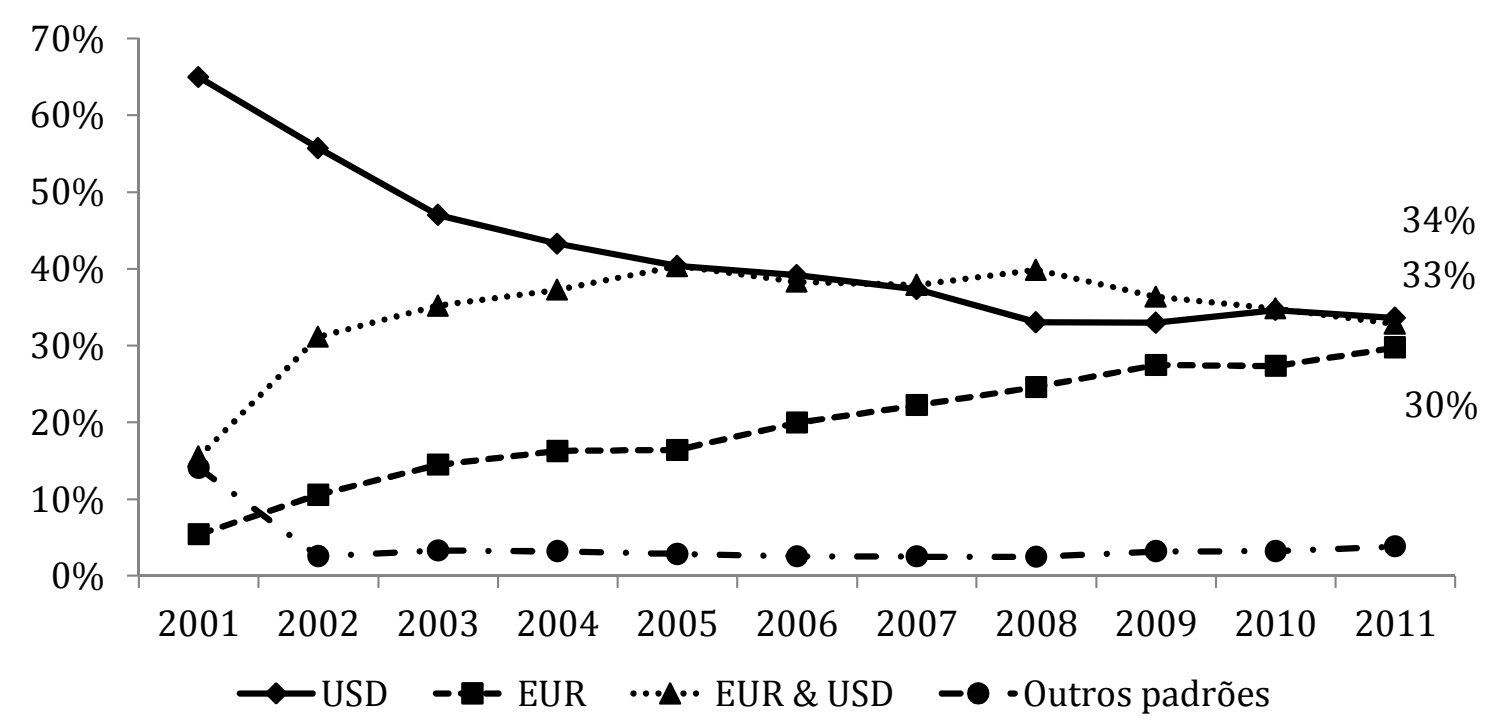

Figura 6: Moedas de pagamento por NCM (8 dígitos) - predominância por valor. 


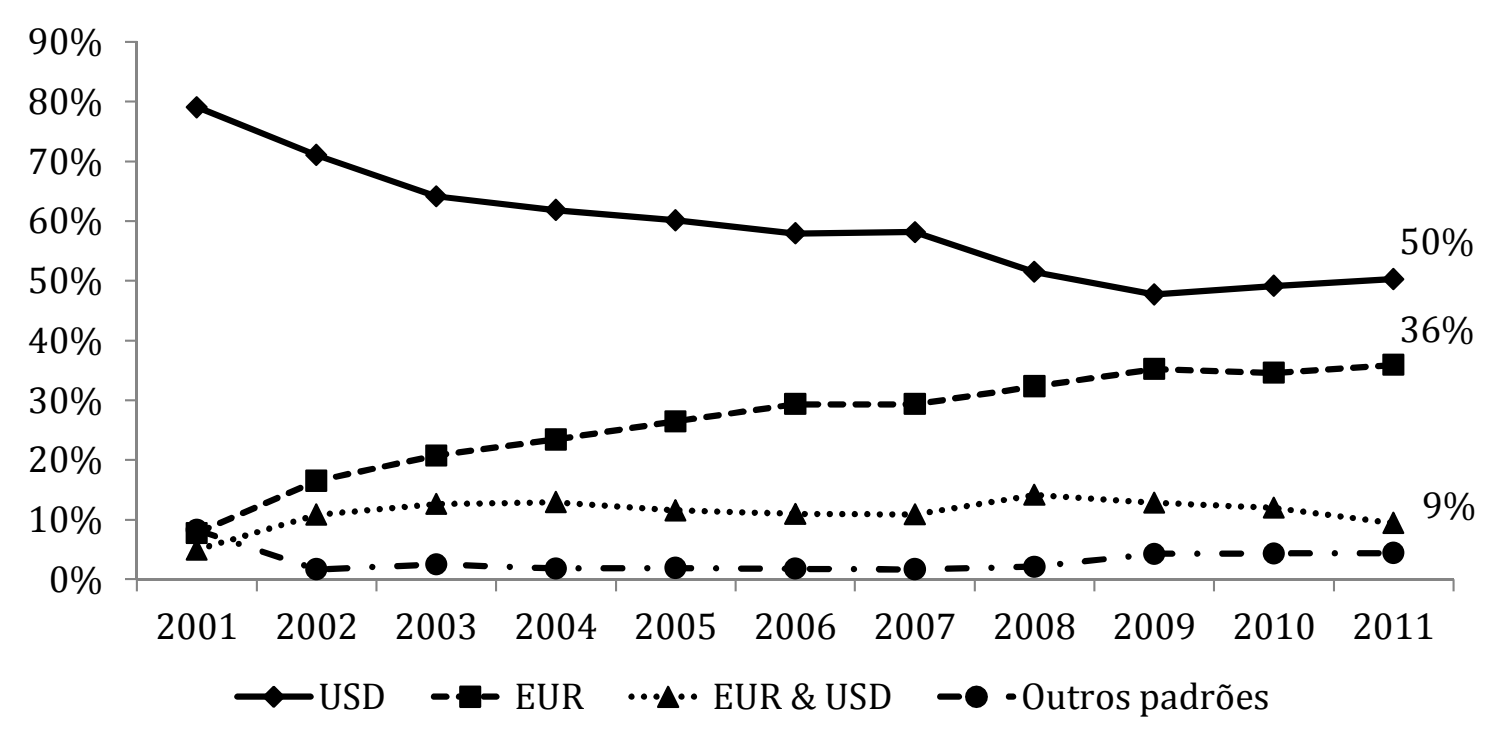

Figura 7: Moedas de pagamento por par firma-NCM (8dígitos/8dígitos) - predominância por valor.

As figuras 8 a 10 a seguir repetem o exercício das figuras 4 a 7, desta vez ponderando a participação de cada padrão de uso pelo valor das operações. Ao contrário do observado nas figuras anteriores, não parece haver tendência de crescimento na participação em valor das operações predominantemente em euro, ou tendência de queda nas exportações predominantemente em dólar. Após um período inicial de queda na participação do dólar e de crescimento na participação do euro, até 2005, a participação das duas moedas parece seguir uma trajetória mais estável, em linha com o observado de forma mais agregada na figura 3 da seção 3.1 . 


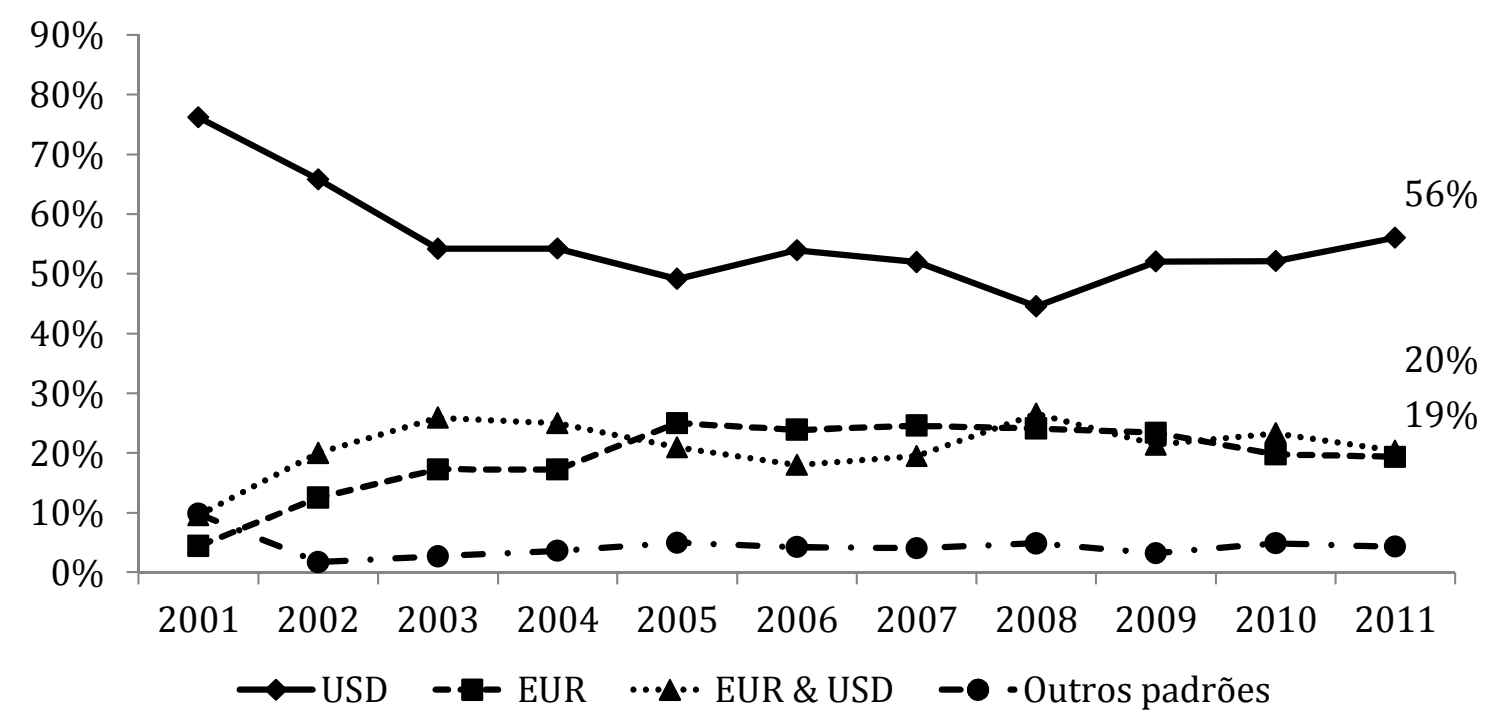

Figura 8: Moedas de pagamento por firma (CNPJ 8 dígitos), participação ponderada pelo valor das operações - predominância na moeda por critério de valor.

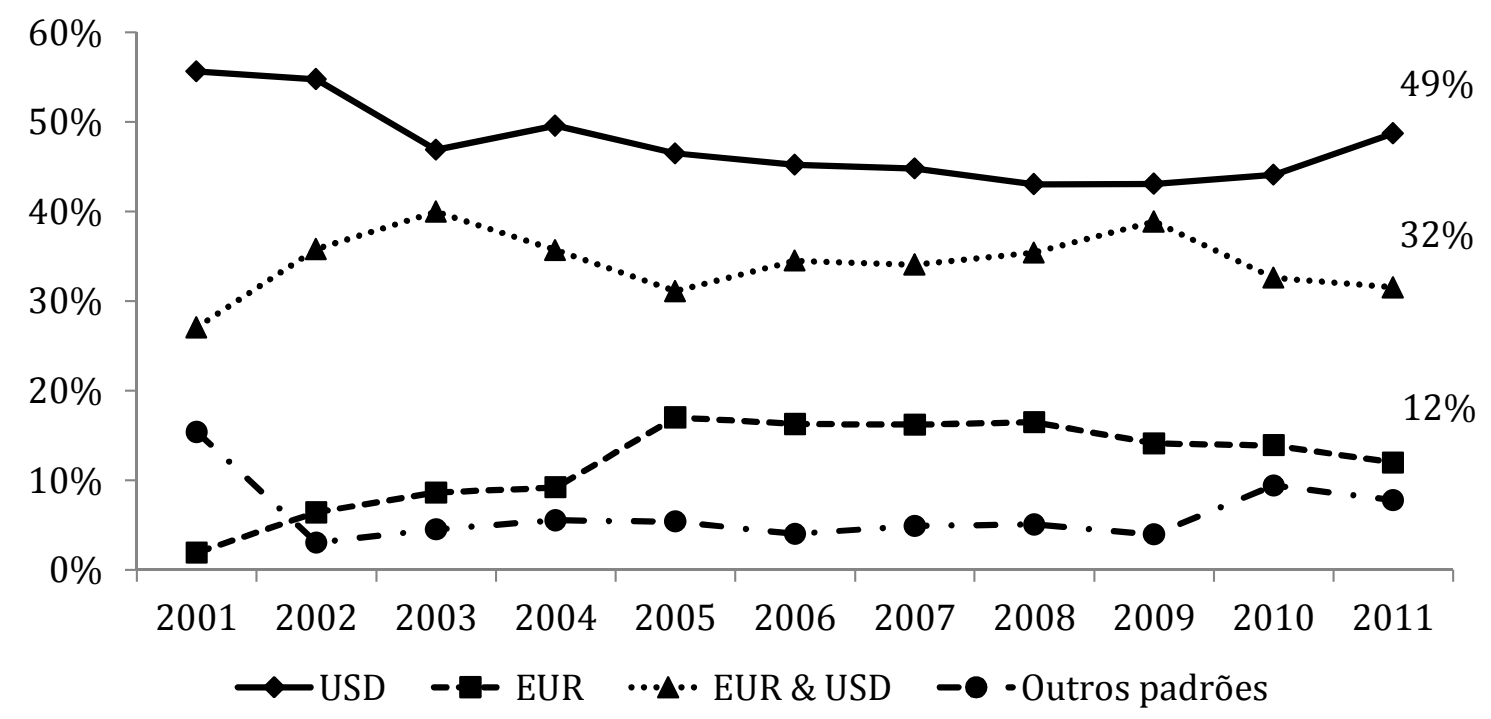

Figura 9: Moedas de pagamento por NCM (8 dígitos), participação ponderada pelo valor das operações - predominância na moeda por critério de valor. 


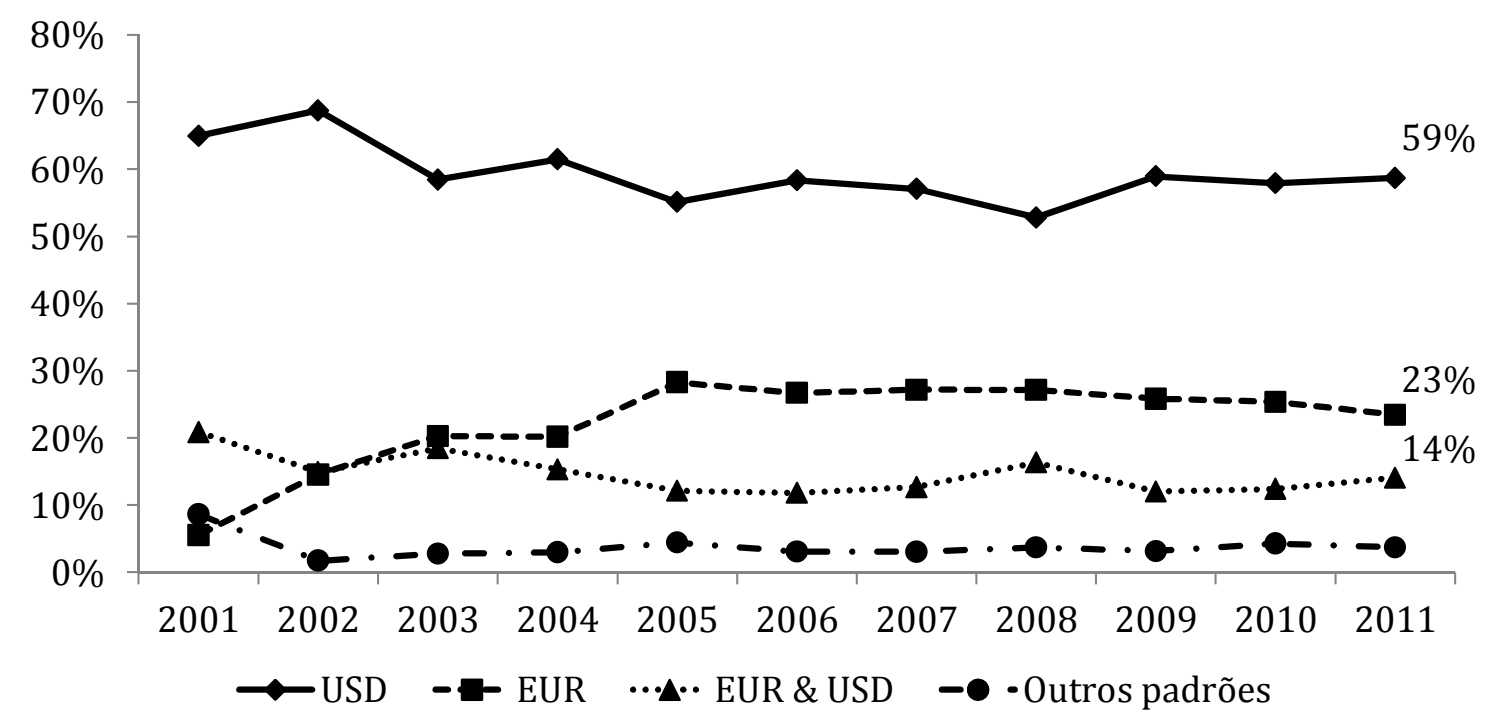

Figura 10: Moedas de pagamento por par Firma-NCM (8dígitos/8dígitos), participação ponderada pelo valor das operações - predominância na moeda por critério de valor.

\subsection{MOEDAS DE INVOICE POR DIVISÃO DA CNAE E POR CAPÍTULO NCM}

A heterogeneidade no uso do euro e do dólar nas exportações de bens diferenciados para a União Europeia pode estar relacionado à atividade da firma exportadora (segundo a sua CNAE) ou ao tipo de produto exportado (segundo a sua NCM). Esta seção apresenta, de forma geral, a participação do euro e do dólar nestes agrupamentos. A amostra é restrita ao período 2007-2011, no qual as participações do euro e do dólar mostraram-se mais estáveis, conforme resultados das seções anteriores. Em algumas atividades CNAE ou capítulos $\mathrm{NCM} / \mathrm{SH}$, o valor e quantidade das operações são concentrados em poucas firmas, e, por razões de sigilo, a abertura completa por atividades e capítulo não é apresentada.

A agregação das exportações por CNAE de fato aponta para variação na participação do euro e do dólar entre as suas divisões (nível de dois dígitos da classificação). A variação, no entanto, não é extrema. Em termos de valor das operações, das 20 principais divisões da indústria de transformação,

4 têm participação do euro menor do que 20\%;

8 têm participação do euro entre $20 \%$ e 50\%;

8 têm participação do euro entre 50\% e 70\%. 
Em termos da quantidade de operações, as variações são similares. Das 20 principais divisões da indústria de transformação,

4 têm participação do euro menor do que 20\%;

- 9 têm participação do euro entre $20 \%$ e $50 \%$;

. 5 têm participação do euro entre $50 \%$ e $70 \%$;

- 2 têm participação do euro maior do que $70 \%$.

A desagregação das exportações por capítulo da NCM/SH (nível de dois dígitos do código) mostra um padrão semelhante. Em termos de valor das operações, dos 38 principais capítulos da NCM/SH,

- 14 têm participação do euro menor do que $20 \%$;

- 8 têm participação do euro entre $20 \%$ e $50 \%$;

11 têm participação do euro entre 50\% e 70\%;

- 5 têm participação do euro maior do que $70 \%$.

Em termos de quantidade de operações, dos 40 principais capítulos da NCM/SH,

14 têm participação do euro menor do que 20\%;

· 15 têm participação do euro entre $20 \%$ e $50 \%$;

· 5 têm participação do euro entre $50 \%$ e $70 \%$;

- 4 têm participação do euro maior do que $70 \%$.

Assim, a desagregação das exportações por atividade CNAE ou capítulo da NCM/SH sugere que a heterogeneidade no uso de moedas de invoice envolve tanto variações entre as atividades/capítulos, quanto dentro de cada atividade/capítulo. As seções 3.6 e 3.7 investigam em que medida outras características da firma estão associadas ao uso do euro como moeda de invoice. 


\subsection{MOEDA DE INVOICE, TAMANHO E FREQUÊNCIA DAS EXPORTAÇÕES}

Esta seção apresenta a participação do euro e do dólar nas exportações desagregadas segundo o tamanho da firma exportadora e a frequência com a qual exporta. A amostra é restrita às exportações de bens diferenciados para a União Europeia no período 2007-2011.

A tabela 16 indica a participação do euro e do dólar nas exportações em função do valor total exportado pela firma. A tabela $\mathbf{1 7}$ indica a participação do euro e do dólar nas exportações em função do número de meses no qual a firma realizou exportações, no período 2007-2011.

As duas agregações indicam um quadro semelhante: a participação do EUR e do USD como moeda de invoice varia pouco em função do valor total ou da frequência de exportação da firma. As tabelas também evidenciam a concentração das exportações em um número relativamente pequeno de firmas, tanto em termos de valor, quanto em termos de quantidade de operações. 
Tabela 16: Participação do EUR e do USD em função do valor total exportado pela firma (definida pelo CNPJ com 8 dígitos).

\begin{tabular}{cc|ccc|ccc}
\hline $\begin{array}{c}\text { Valor exportado pela } \\
\text { firma (CNPJ 8) no } \\
\text { período, em US\$ }\end{array}$ & $\begin{array}{c}\text { Número } \\
\text { de firmas }\end{array}$ & $\begin{array}{c}\text { \% no total da } \\
\text { amostra }\end{array}$ & USD & EUR & $\begin{array}{c}\text { P no total da } \\
\text { amostra }\end{array}$ & USD & EUR \\
\hline Até 10 mil & 1.103 & $0 \%$ & $65 \%$ & $34 \%$ & $0 \%$ & $59 \%$ & $38 \%$ \\
\hline 10 mil a 100 mil & 2.412 & $0 \%$ & $61 \%$ & $38 \%$ & $1 \%$ & $59 \%$ & $37 \%$ \\
\hline 100 mil a 500 mil & 1.683 & $1 \%$ & $60 \%$ & $38 \%$ & $2 \%$ & $55 \%$ & $44 \%$ \\
\hline 500 mil a 1 milhão & 622 & $1 \%$ & $65 \%$ & $34 \%$ & $2 \%$ & $66 \%$ & $34 \%$ \\
\hline 1 milhão a 5 milhões & 1.081 & $6 \%$ & $62 \%$ & $36 \%$ & $8 \%$ & $61 \%$ & $37 \%$ \\
\hline 5 milhões a 10 milhões & 284 & $4 \%$ & $56 \%$ & $41 \%$ & $5 \%$ & $53 \%$ & $45 \%$ \\
\hline 10 milhões a 50 milhões & 399 & $19 \%$ & $53 \%$ & $44 \%$ & $19 \%$ & $52 \%$ & $46 \%$ \\
\hline 50 milhões a 100 milhões & 62 & $9 \%$ & $64 \%$ & $34 \%$ & $6 \%$ & $48 \%$ & $47 \%$ \\
\hline Acima de 100 milhões & 74 & $59 \%$ & $69 \%$ & $29 \%$ & $57 \%$ & $52 \%$ & $46 \%$ \\
\hline Total & 7.720 & $100 \%$ & $65 \%$ & $34 \%$ & $100 \%$ & $53 \%$ & $45 \%$ \\
\hline
\end{tabular}


Tabela 17: Participação do EUR e do USD em função da frequência de exportação da firma (definida pelo CNPJ com 8 dígitos).

\begin{tabular}{ccccc|ccc}
\hline $\begin{array}{c}\text { Meses em que a firma } \\
\text { (CNPJ 8) exportou no } \\
\text { período }\end{array}$ & $\begin{array}{c}\text { Número } \\
\text { de firmas }\end{array}$ & $\begin{array}{c}\text { Participação em valor } \\
\text { no total da } \\
\text { amostra }\end{array}$ & USD & EUR & $\begin{array}{c}\text { Participação em quantidade } \\
\text { amostra }\end{array}$ & USD & EUR \\
\hline 1 & 2.038 & $0 \%$ & $65 \%$ & $34 \%$ & $0 \%$ & $53 \%$ & $45 \%$ \\
\hline 2 a 5 & 2.095 & $1 \%$ & $70 \%$ & $29 \%$ & $1 \%$ & $56 \%$ & $40 \%$ \\
\hline 6 a 10 & 911 & $1 \%$ & $77 \%$ & $22 \%$ & $1 \%$ & $57 \%$ & $42 \%$ \\
\hline 11 a 20 & 988 & $7 \%$ & $78 \%$ & $20 \%$ & $4 \%$ & $45 \%$ & $50 \%$ \\
\hline 21 a 40 & 839 & $9 \%$ & $70 \%$ & $29 \%$ & $6 \%$ & $62 \%$ & $36 \%$ \\
\hline 41 a 50 & 335 & $10 \%$ & $51 \%$ & $47 \%$ & $19 \%$ & $21 \%$ & $75 \%$ \\
\hline 51 a 60 & 514 & $71 \%$ & $64 \%$ & $34 \%$ & $68 \%$ & $61 \%$ & $37 \%$ \\
\hline Total & 7.720 & $100 \%$ & $65 \%$ & $34 \%$ & $100 \%$ & $53 \%$ & $45 \%$ \\
\hline
\end{tabular}

\subsection{MOEDA DE INVOICE E INVESTIMENTO ESTRANGEIRO DIRETO}

Esta seção utiliza a base de dados do Censo de Capitais Estrangeiros do Banco Central do Brasil para identificar firmas cujo capital tenha participação de investidores não residentes. Dada a prevalência de transações intra-firma no comércio internacional, a origem do capital da firma exportadora poderia indicar, no caso de firmas com investimento direto europeu, uma probabilidade maior de que as transações tenham ocorrido entre empresas do mesmo grupo. A conjectura é que estas transações intragrupo poderiam utilizar preferencialmente o euro como moeda de invoice, dada a origem do capital.

A amostra do Siscomex é novamente restrita às exportações de bens diferenciados para a União Europeia, no período 2007-2011.

Os dados do Censo de Capitais utilizados neste exercício apresentam dois problemas para o objetivo da análise. O primeiro ponto é que a base utilizada é relativa ao Censo de Capitais com ano base 2010, de forma que relações de investimento estrangeiro direto extintas antes ou criadas depois do ano base não estão presentes nas informações utilizadas. Mais 
importante, o Censo só atinge as firmas brasileiras cuja participação do capital estrangeiro seja direta. Caso a cadeia de propriedade da firma se dê, indiretamente, através de uma segunda subsidiária da firma estrangeira no Brasil, a firma que recebe indiretamente o capital não fará parte do banco de dados do Censo. Nos resultados abaixo, os casos mais evidentes e de maior relevância de firmas sob propriedade indireta de capital estrangeiro foram adicionados manualmente à tabela de empresas com investimento estrangeiro direto.

Também é importante observar que a determinação do país de origem do capital pode não ser trivial, dada a passagem de muitas operações de investimento por centros financeiros internacionais, a exemplo da Holanda. Neste sentido, o Censo diferencia o país do investidor imediato do país do investidor final. É esta última informação que é utilizada nos resultados abaixo.

A tabela 18 apresenta a participação do euro e do dólar nas exportações segundo a presença de investimento estrangeiro direto (IED). A origem do capital do IED é desagregada entre União Europeia e outras origens. Nas exportações de firmas com IED de origem europeia, a participação do euro em valor é maior do que nas demais categorias, em linha com a conjectura feita anteriormente. No entanto, em quantidade, não parece haver diferença relevante entre firmas com ou sem IED, independentemente da origem do seu capital. 
Tabela 18: Participação do EUR e do USD em função da presença de capital estrangeiro na firma exportadora (definida pelo CNPJ com 8 dígitos).

\begin{tabular}{cccc|ccc}
\hline & \multicolumn{3}{c}{ Participação em valor } & \multicolumn{2}{c}{ Participação em quantidade } \\
IED/Origem do capital & $\begin{array}{c}\text { \% no total da } \\
\text { amostra }\end{array}$ & USD & EUR & $\begin{array}{c}\text { no total da } \\
\text { amostra }\end{array}$ & USD & EUR \\
\hline Sem IED & $51 \%$ & $74 \%$ & $24 \%$ & $48 \%$ & $48 \%$ & $49 \%$ \\
\hline União Europeia & $37 \%$ & $52 \%$ & $47 \%$ & $40 \%$ & $57 \%$ & $42 \%$ \\
\hline Outra origem & $12 \%$ & $65 \%$ & $30 \%$ & $12 \%$ & $57 \%$ & $40 \%$ \\
\hline Total & $100 \%$ & $65 \%$ & $34 \%$ & $100 \%$ & $53 \%$ & $45 \%$ \\
\hline
\end{tabular}

\subsection{COMENTÁRIOS GERAIS}

De forma geral, os resultados apresentados nas seções 3.1 a 3.7 são consistentes com a literatura que analisa o uso das moedas de invoice no comércio internacional. O uso do real é pouco expressivo, restrito a operações de baixo valor médio com países do Mercosul e Bolívia, padrão similar ao observado em países como Coréia do Sul, Tailândia e países do Leste Europeu $^{25}$. O dólar como moeda veículo é predominante em todas as categorias de bens, e, em especial, na exportação de bens homogêneos.

$\mathrm{Na}$ exportação de bens diferenciados para os países da União Europeia, o euro também tem papel relevante, mas ainda menor do que aquele desempenhado pelo dólar. Nesse subconjunto das exportações, a participação do euro varia entre atividades e tipos de produto, mas sua participação permanece relevante na maioria deles. Por outro lado, a participação do euro como moeda de invoice não parece associado de maneira evidente a características da firma, como frequência ou valor total das suas exportações, ou à presença de capital estrangeiro.

Enquanto esta seção buscou caracterizar o uso da moeda de invoice nas exportações brasileiras, e, em especial, o uso do euro como moeda de invoice nas exportações para a União Europeia, as seções 4 e 5 investigam se os preços de exportação se comportam de maneira diferente, dada a moeda de invoice. A seção 4 discute o uso do valor unitário como

${ }^{25}$ Goldberg e Tille (2005). 
proxy do preço das mercadorias; e a seção 5 parte dos valores unitários para estimar modelos dinâmicos de pass-through em função da moeda de invoice. 


\section{VALOR UNITÁRIO NA AMOSTRA}

Esta seção apresenta resultados descritivos sobre os valores unitários na amostra de exportações de bens diferenciados para a União Europeia, no período 2001-2011, com ênfase na possibilidade de controlar variações de qualidade das mercadorias através da identificação simultânea do seu código de classificação NCM no nível de 8 dígitos, da firma exportadora, e do país de destino. Os resultados indicam a dificuldade inerente ao uso do valor unitário como proxy do preço dos bens. Por outro lado, sugerem que o controle simultâneo por NCM, firma e destino contribui para mitigar os problemas de variação de qualidade e composição observados no uso exclusivo da NCM, ou mesmo no uso simultâneo da NCM e do país de destino.

\subsection{CONSTRUÇÃO DE VALORES UNITÁRIOS}

Nos dados do Siscomex não existe informação direta sobre o preço individual dos bens. Como em outras pesquisas baseadas em dados alfandegários, é preciso construir uma proxy para os preços individuais com base no valor total e na quantidade de bens da transação. Dentre os campos disponíveis no Siscomex para o valor da transação, este estudo utiliza o campo correspondente ao valor das mercadorias no seu ponto de embarque. Como discutido na seção 2.1.1.5, este campo de valor não inclui despesas com frete internacional e seguros.

Três campos no Siscomex correspondem à quantidade exportada:

o peso das mercadorias (em $\mathrm{kg}$ );

a quantidade dada em unidade específica para cada NCM, definida pelo MDIC quilograma líquido, tonelada métrica líquida, pares, metro quadrado, número (unidades), entre outras;

- a quantidade dada em unidade comercial definida pelo exportador.

No último caso, o exportador também informa, em um campo texto, qual é a unidade utilizada.

As três alternativas foram consideradas, mas, em análise preliminar, optou-se pelo uso do campo referente ao peso. Aparentemente os valores informados nos campos referentes à unidade específica da NCM e à unidade comercial são menos consistentes que o valor 
informado no campo peso. O campo da unidade comercial apresenta a dificuldade adicional de identificar exatamente a unidade utilizada, dado que a informação é disponibilizada em um campo de tipo texto - e.g. "UM", "UNIDADE", “UND”, "UN" e "UNID” são utilizadas para indicar que a unidade comercial é o número de itens; "CAIXAS", "CX", "CAIXA", "CXS" indicam que a unidade comercial utilizada é uma caixa das mercadorias.

O Texto para Discussão 121 da Funcex ${ }^{26}$ indica que o peso das mercadorias também foi escolhido como indicador de quantidade para a construção dos índices de preço e quantum das exportações e importações brasileiras:

A preferência pelo peso em lugar de quantidades justifica-se pelo fato de que a qualidade daquela informação é melhor do que desta, por aquela sofrer uma crítica mais criteriosa pela SECEX. Isto se refletiu em uma distribuição empírica dos preços relativos $\left(p_{i}^{t} / p_{i}^{t-1}\right)$, quando calculados com os pesos, com variância bem menor do que quando se utilizou as quantidades, caso em que a presença de outliers, e de grandes variações de preços relativos foi mais comum.

Independentemente da escolha da medida de quantidade, o uso de valores unitários apresenta problemas. Conforme análise em Alterman (1991), os valores unitários não refletem apenas mudanças de preço. O uso da classificação de bens (a NCM no caso brasileiro), mesmo no seu nível mais detalhado, não é capaz de controlar mudanças de qualidade de um bem ao longo do tempo, e não identifica inequivocamente a mercadoria, de forma que as mudanças no valor unitário podem refletir mudanças na qualidade e no mix de produtos classificados na mesma NCM, mesmo em horizontes muito curtos de tempo.

Essa dificuldade é evidente nos dados do Siscomex Exportação. Nos parágrafos a seguir, uma mercadoria é definida como um trio NCM-Firma-País de destino. Tanto a NCM, quanto o CNPJ são utilizados no nível de 8 dígitos.

São comuns na base do Siscomex Exportação casos em que há mais de um registro de exportação ${ }^{27}$ do mesmo produto (NCM), da mesma firma exportadora, para o mesmo país de destino, e com mesma data (dia) de registro. A figura 11 indica a frequência destas ocorrências na amostra, em função da quantidade de registros de mercadorias idênticas com

\footnotetext{
${ }^{26}$ Guimarães et al (1997), "Índices de preço e quantum das exportações brasileiras”.

${ }^{27}$ Mais especificamente, mais de um anexo de RE, conforme seção 2.1.
} 
mesma data de registro. A categoria "1" indica os casos sem repetição, em que só existe um registro para uma dada mercadoria no mesmo dia. De acordo com os resultados abaixo, 70\% dos registros na base correspondem a casos em que uma mesma mercadoria tem mais de um registro de exportação no mesmo dia.

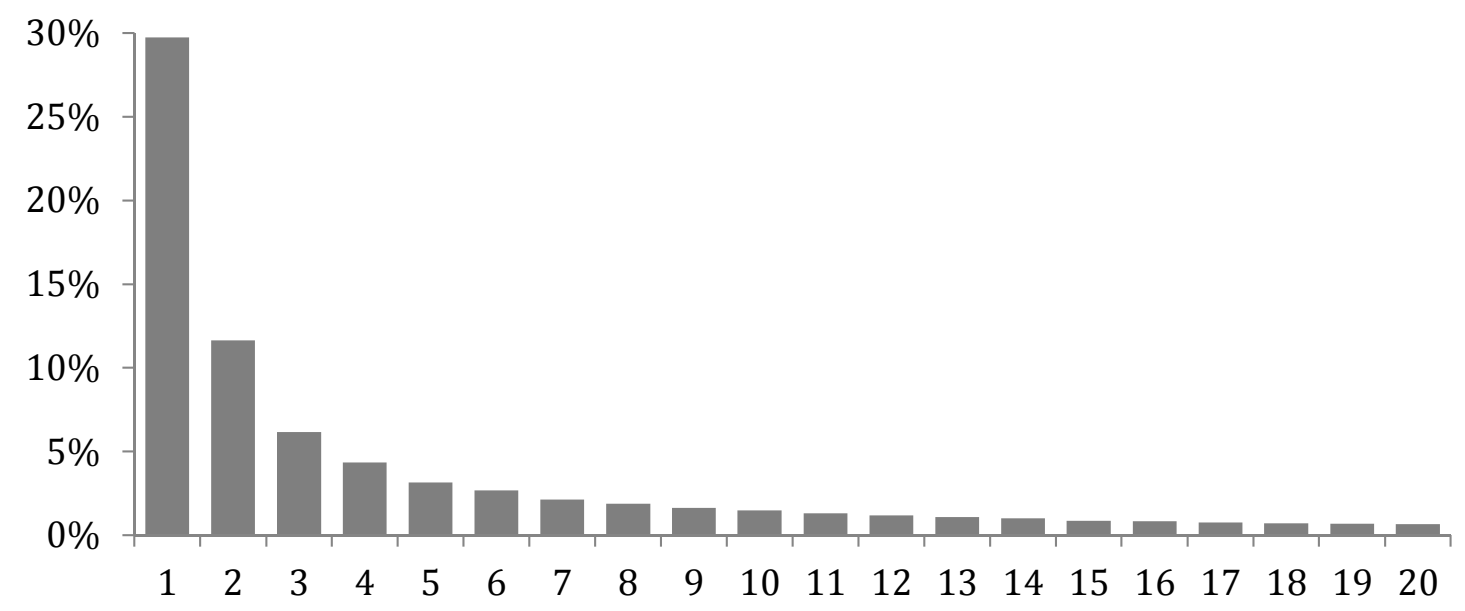

Figura 11: Frequência de ocorrência de registros com mercadorias idênticas (NCMFirma-Destino) e mesma data de início do RE.

A figura 8 repete o exercício para os casos de registros de exportação no mesmo mês. $\mathrm{Na}$ amostra, $87 \%$ dos registros na base correspondem a casos em que a mercadoria é exportada mais de uma vez no mesmo mês. 


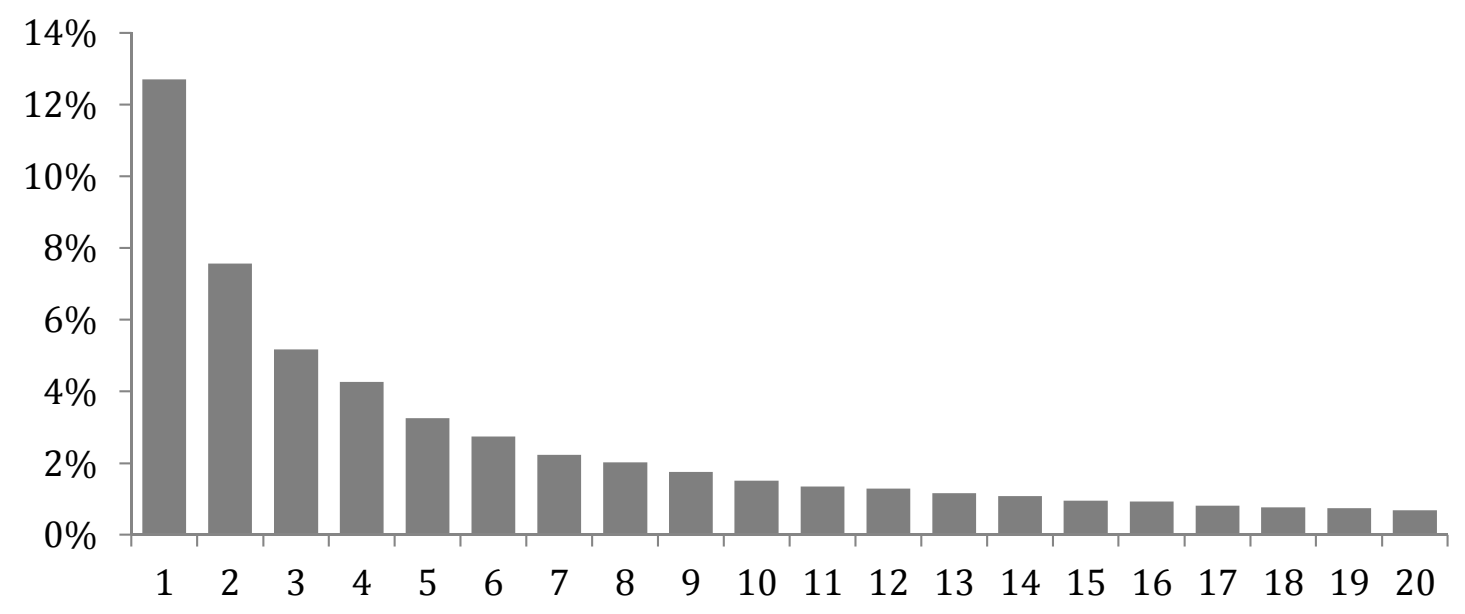

Figura 12: Frequência de ocorrência de registros com mercadorias idênticas (NCMFirma-Destino) e mesmo mês de início do RE.

Caso o controle por NCM, firma e país de destino identificasse perfeitamente o bem exportado, o valor unitário de mercadorias idênticas exportadas no mesmo dia ou mês deveria variar pouco. A figura 13 indica a distribuição da diferença percentual entre o valor unitário da mercadoria e o valor médio de mercadorias idênticas exportadas no mesmo dia. O valor médio foi calculado como a razão entre a soma dos valores (em USD) e a soma dos pesos dos registros. Nos casos em que a mercadoria é exportada mais de uma vez por dia, $56 \%$ dos registros têm valor unitário que desvia mais de $10 \%$ em relação ao valor médio do dia; em $39 \%$ dos casos a divergência é maior do que $20 \%$. Vale notar que quando há apenas dois registros no mesmo dia, uma diferença de $10 \%$ em relação à média indica uma diferença de $20 \%$ entre os dois valores unitários. A figura 14 repete o exercício acima para mercadorias idênticas exportadas no mesmo mês, com resultados muito similares.

Também foi testada a exclusão de operações com valor e peso muito baixos, e valores unitários muito elevados. Mesmo neste caso, a dispersão dos valores unitários é elevada, apesar de menor do que para os casos anteriores. Excluindo operações com peso menor do que $100 \mathrm{~kg}$, valor menor do que US\$100, e valor unitário maior do que US\$10 mil, 49\% dos registros têm valor unitário que desvia mais de $10 \%$ em relação ao valor médio do dia; e em $30 \%$ dos casos a divergência é maior do que $20 \%$.

Estes resultados são evidências fortes de que mesmo o controle simultâneo por NCM (no seu nível mais detalhado), firma exportadora, e país de destino deixa espaço significativo 
para variações no produto exportado, em linha com as observações feitas por Alterman (1991).

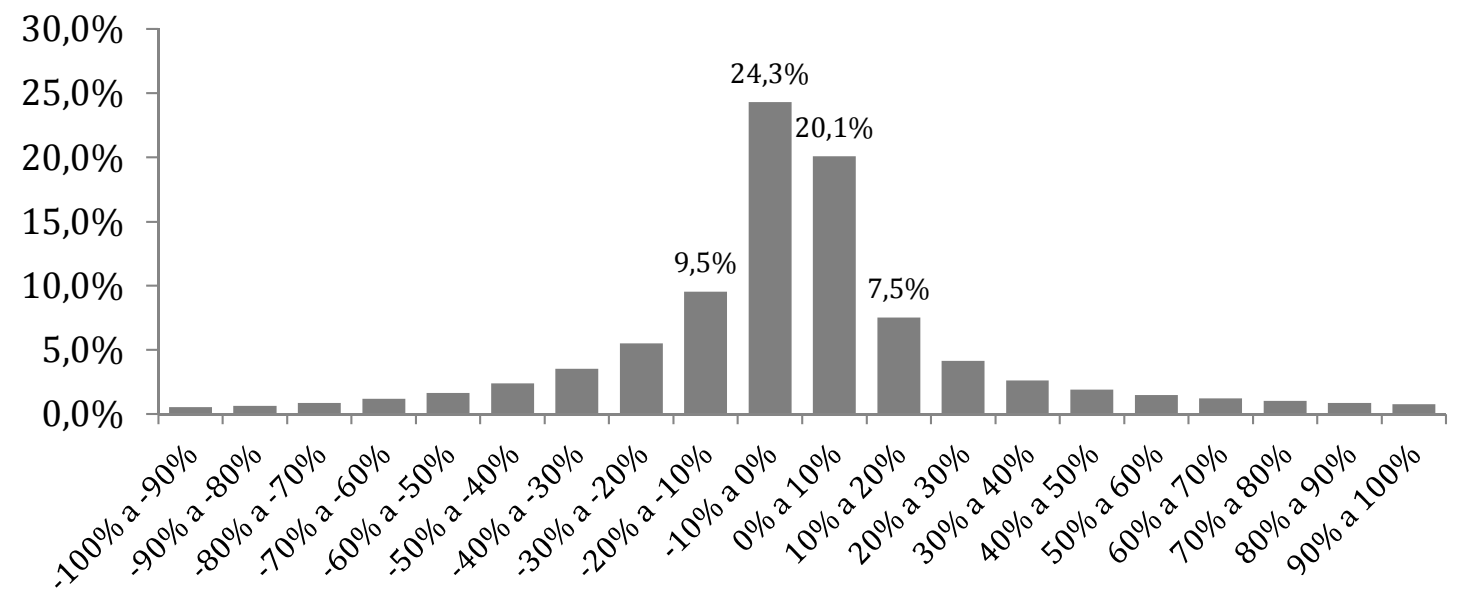

Figura 13: Dispersão de preços entre bens idênticos exportados no mesmo dia.

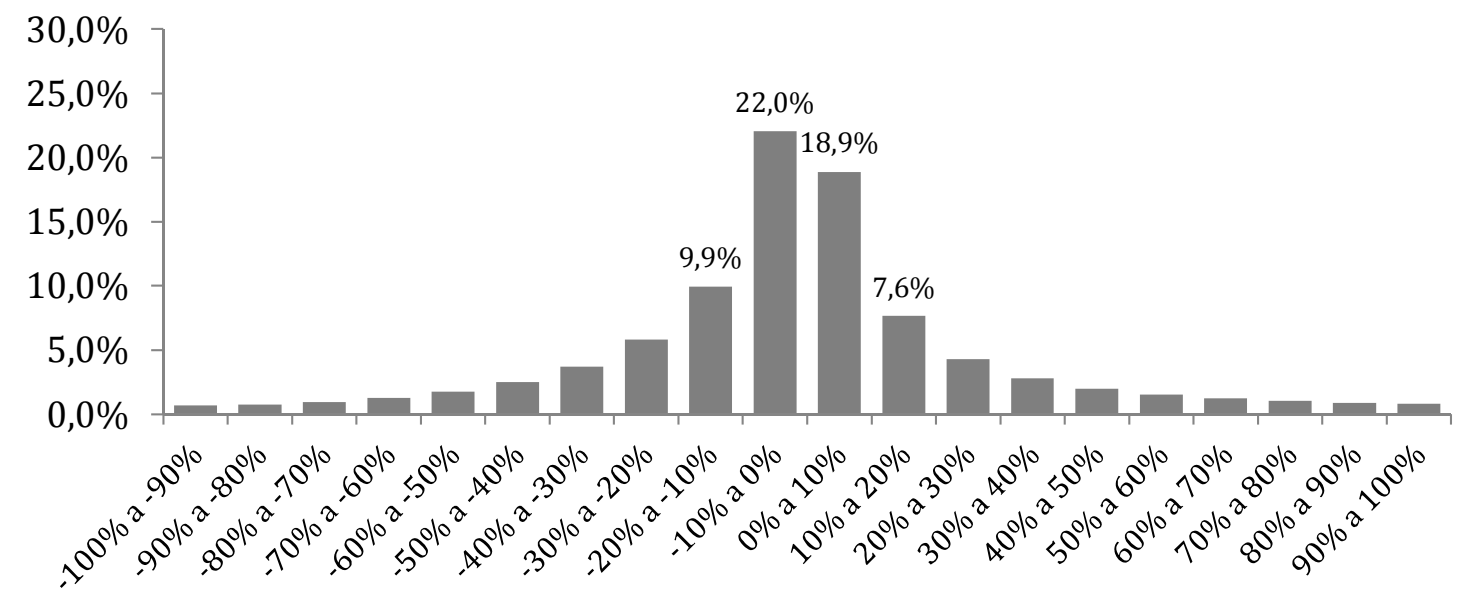

Figura 14: Dispersão de preços entre bens idênticos exportados no mesmo mês. 


\subsection{VARIÂNCIA DO VALOR UNITÁRIO EXPLICADA PELA FIRMA, PRODUTO E PAÍS DE DESTINO}

Feitas as ressalvas da seção 4.1, essa seção segue a análise de Fabling e Sanderson (2013) para justificar o uso do trio Firma-NCM-Destino como forma de minimizar os efeitos de composição e qualidade inerentes ao uso de dados alfandegários e valores unitários. Nos parágrafos a seguir, uma mercadoria é definida como um trio NCM-Firma-País de destino. Tanto a NCM quanto o CNPJ são utilizados no nível de 8 dígitos.

A coluna 1 da tabela 19 indica o $\mathrm{R}^{2}$ da regressão do logaritmo do valor unitário contra dummies com quatro níveis diferentes de detalhe. A amostra é restrita a mercadorias que ocorram pelo menos duas vezes no período. Os resultados indicam que a identidade da firma, em conjunto com o código NCM do produto e o país de destino, ajuda a explicar a variação do valor unitário na amostra, e que seu controle deve minimizar o problema de composição discutido na seção anterior. A variação residual inclui mudanças no preço dos produtos ao longo do tempo, além de mudanças na composição e qualidade dos produtos conforme a discussão na seção 4.1 .

Seguindo Fabling e Sanderson (2013), o exercício é repetido para outros subgrupos da amostra. A coluna 2 restringe o teste a mercadorias que tenham sido exportadas pelo menos 10 vezes no período. Os resultados indicam que o poder explicativo do trio Firma-NCMDestino não é função de mercadorias com baixa ocorrência na amostra. As colunas 3 a 5 indicam que as mesmas conclusões são válidas para o subgrupo de bens diferenciados pelo critério liberal de Rauch.

Este resultado justifica o uso do trio Firma-NCM-Destino nas análises das seções a seguir para minimizar o efeito da variação de composição e qualidade nos resultados. 
Tabela 19: Variação $\left(\mathbf{R}^{2}\right)$ no logaritmo do valor unitário explicada por efeitos fixos.

\begin{tabular}{lccccc} 
& Quant $>=2$ & Quant $>=10$ & $\begin{array}{c}\text { Quant }>=2, \\
\text { Diferenciado } \\
(1)\end{array}$ & $\begin{array}{c}\text { Quant }>=10, \\
\text { Diferenciado }\end{array}$ & $\begin{array}{c}\text { Quant }>=20, \\
\text { Diferenciado } \\
(2)\end{array}$ \\
\hline NCM & 0,76 & 0,77 & 0,70 & 0,72 & 0,72 \\
\hline Firma & 0,77 & 0,78 & 0,73 & 0,74 & 0,74 \\
\hline NCM-Destino & 0,82 & 0,83 & 0,77 & 0,79 & 0,79 \\
\hline Firma-NCM-Destino & 0,89 & 0,89 & 0,87 & 0,86 & 0,86 \\
\hline N & 7.734 .458 & 7.317 .200 & 5.966 .949 & 5.632 .155 & 5.403 .041 \\
\hline
\end{tabular}

\subsection{RIGIDEZ DE PREÇO}

O uso de valores unitários torna difícil detectar com exatidão a ocorrência de rigidez estrita (exata) de preços, tanto pelos problemas de composição e qualidade discutidos na seção 4.1, quanto por erros derivados do uso do peso como indicador de quantidade.

Apesar destas limitações, esta seção calcula o percentual de exportações consecutivas de uma mesma mercadoria em que o valor unitário entre as duas exportações permanece o mesmo (a menos de um intervalo de tolerância, dada a imprecisão do valor unitário como proxy do preço da mercadoria). Como nas seções anteriores, a mercadoria é definida como um trio NCM-Firma-País de destino.

Este teste é realizado sobre a amostra já agregada por data da operação. Todos os registros de exportação de uma mercadoria com mesma data (mesmo dia) são agregados em um único registro. $\mathrm{O}$ valor unitário do registro agregado é obtido como a razão entre a soma dos valores e a soma dos pesos das operações agregadas.

Após a agregação, dois conjuntos de variações são construídas, um para registros com invoice em euro e outro para operações com invoice em dólar. $\mathrm{Na}$ construção destes conjuntos, apenas exportações consecutivas na mesma moeda de invoice são consideradas. A tabela 20 indica, para cada moeda de invoice, o percentual dos valores unitários que se mantêm constantes em euro e dólar, para um intervalo de tolerância de 0,1\%. As tabelas 21 e 22 repetem o exercício para tolerâncias de $0,2 \%$ e $0,5 \%$, e a tabela 23 , para o caso de bens diferenciados.

Os resultados são consistentes com a hipótese de que, no curto prazo, a rigidez de preços se manifesta na moeda de invoice das operações. Considerando o intervalo de 
tolerância de $0,5 \%, 7,7 \%$ das operações em euro mantêm seu valor unitário (em euro) na transação seguinte; se a variação do valor unitário for calculada em dólar, o percentual cai para 3,8\%. Quando a moeda de invoice é o dólar, 14,2\% das operações mantém seu valor unitário (em dólar) na transação seguinte; caso a variação seja calculada em euro, o percentual cai para $4 \%$.

O resultado é consistente com aqueles apresentados por Fabling e Sanderson (2013) para o caso das exportações da Nova Zelândia.

Tabela 20: Rigidez de preço entre transações consecutivas - tolerância de 0,1\%.

\begin{tabular}{crr}
\multicolumn{2}{c}{ Moeda de invoice } \\
$\begin{array}{c}\text { Moeda na qual a } \\
\text { variação é calculada }\end{array}$ & USD & EUR \\
\hline USD & $\mathbf{1 3 , 1 \%}$ & $1,2 \%$ \\
\hline EUR & $1,2 \%$ & $\mathbf{2 , 0 \%}$ \\
\hline $\mathrm{N}$ & 1.245 .034 & 608.815 \\
\hline
\end{tabular}

Tabela 21: Rigidez de preço entre transações consecutivas - tolerância de 0,2\%.

\begin{tabular}{crr} 
& \multicolumn{2}{c}{ Moeda de invoice } \\
$\begin{array}{c}\text { Moeda na qual a } \\
\text { variação é calculada }\end{array}$ & USD & EUR \\
\hline USD & $\mathbf{1 4 , 0 \%}$ & $2,3 \%$ \\
\hline EUR & $2,4 \%$ & $\mathbf{3 , 9 \%}$ \\
\hline $\mathrm{N}$ & 1.245 .034 & 608.815 \\
\hline
\end{tabular}


Tabela 22: Rigidez de preço entre transações consecutivas - tolerância de $0,5 \%$.

\begin{tabular}{crr}
\multicolumn{3}{c}{ Moeda de invoice } \\
$\begin{array}{c}\text { Moeda na qual a } \\
\text { variação é calculada }\end{array}$ & \multicolumn{1}{c}{ USD } & \multicolumn{1}{c}{ EUR } \\
\hline USD & $\mathbf{1 6 , 3 \%}$ & $5,5 \%$ \\
\hline EUR & $5,8 \%$ & $\mathbf{9 , 0 \%}$ \\
\hline $\mathrm{N}$ & 1.245 .034 & 608.815 \\
\hline
\end{tabular}

Tabela 23: Rigidez de preço entre transações consecutivas - bens diferenciados e tolerância de $0,2 \%$.

\begin{tabular}{crr} 
& \multicolumn{2}{c}{ Moeda de invoice } \\
$\begin{array}{c}\text { Moeda na qual a } \\
\text { variação é calculada }\end{array}$ & USD & EUR \\
\hline USD & $\mathbf{1 0 , 7 \%}$ & $1,9 \%$ \\
\hline EUR & $1,8 \%$ & $\mathbf{3 , 0 \%}$ \\
\hline $\mathrm{N}$ & 758.061 & 475.532 \\
\hline
\end{tabular}




\section{DINÂMICA DO PASS-THROUGH EM FUNÇÃO DA MOEDA DE INVOICE}

Os resultados da seção 4.3 são evidência de que a rigidez de preço no curto prazo ocorre com mais frequência na moeda de invoice. Gopinath et al (2010) demonstram, no entanto, que a rigidez não é necessariamente nominal. Mesmo após a primeira mudança de preços, os coeficientes de pass-through para mercadorias com invoice na moeda local e com invoice na moeda do exportador são estatisticamente diferentes: o pass-through na moeda do exportador é quase completo (96\%), enquanto o pass-through na moeda local é de $24 \%$, ambos para o caso de bens diferenciados.

Para testar este padrão geral, a seção 5.1 segue Gopinath et al (2010) e constrói índices agregados de preços para exportações com invoice em USD e EUR separadamente. Estes índices são usados para estimar modelos dinâmicos que permitem observar as respostas de curto e médio prazos a variações no câmbio.

A seção 5.2 segue Fabling e Sanderson (2013) e estima modelos para variações de preço ao nível da mercadoria, definida pelo trio NCM-Firma-Destino.

Para os dois casos é importante ressaltar que a fonte de variação para a dinâmica analisada na dissertação é menos rica do que aquela observada nos dados de Gopinath et al (2010) e, em particular, nos dados de Fabling e Sanderson (2013). Gopinath et al (2010) observa importações americanas com origem em países da Europa Continental, além de Japão, Reino Unido, Austrália, e Canadá. Adicionalmente, as moedas de invoice analisadas dividem-se entre os dois extremos dados pela moeda local (USD) e pela moeda do país exportador. No caso de Fabling e Sanderson (2013), a variação nos destinos também é maior (Europa, Estados Unidos, Ásia, e Oceania), além de também observarem o efeito do uso da moeda própria (NZD) na exportação para todos os destinos.

No caso do Brasil, a heterogeneidade na moeda de invoice é observada de forma relevante para apenas alguns poucos destinos. As exportações em real também são limitadas às exportações para os países do Mercosul e Bolívia, e, mesmo nestes casos, a operações de valor médio muito reduzido.

A fonte de variação para as estimativas de pass-through na amostra selecionada para a dissertação é limitada, portanto, às variações do euro e do dólar ante o real, além da variação entre as duas moedas. 
A figura 15 abaixo mostra a taxa de câmbio do dólar e do euro contra o real no período 2001-2011. Após a forte desvalorização em 2002, o real segue uma trajetória de valorização em relação às duas moedas até a crise financeira em setembro de 2008 , quando a moeda desvaloriza fortemente. Após o pico da crise, o real volta a valorizar-se, e mantém alguma estabilidade a partir de 2010. No período em análise, a correlação entre as taxas de câmbio do euro e do dólar contra o real é elevada - da ordem de 0,8 para variações mensais.

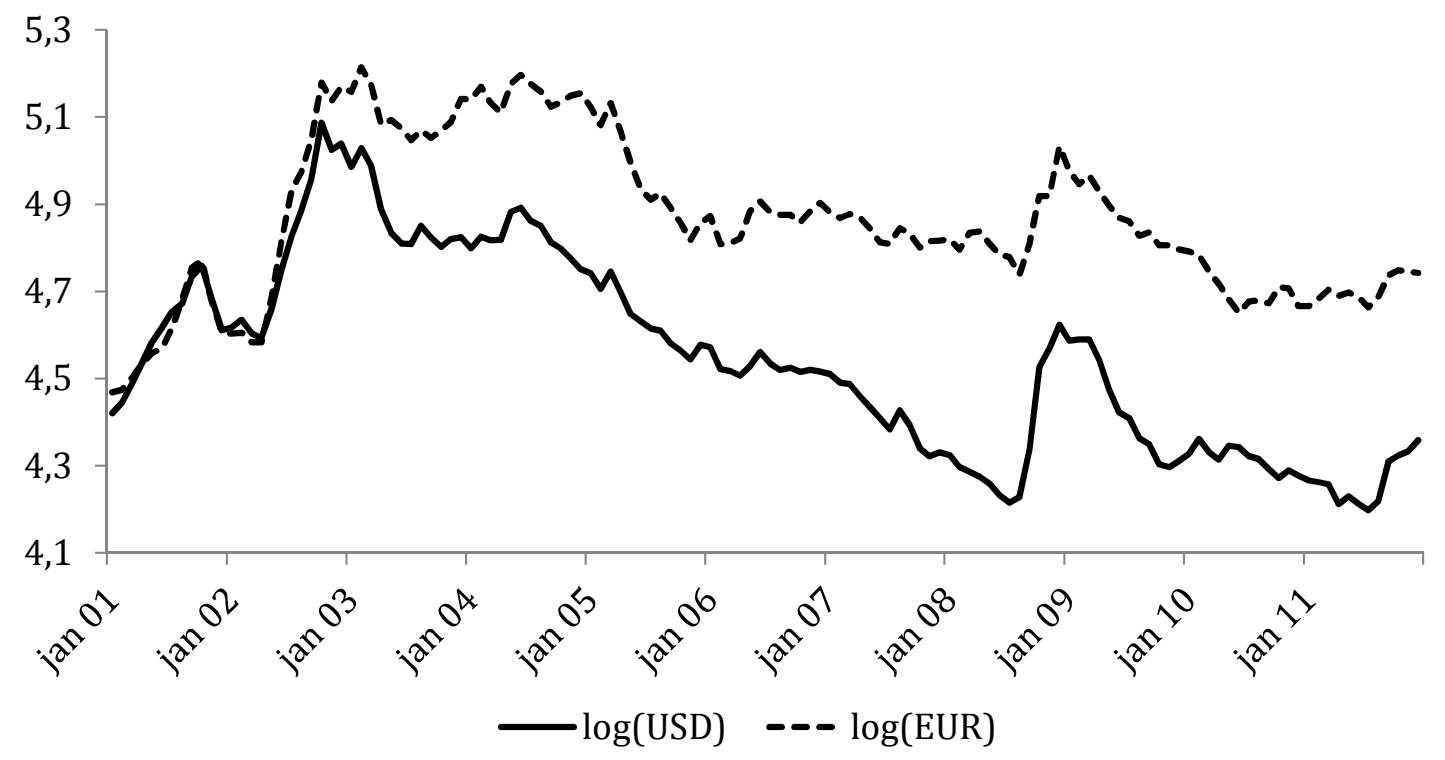

Figura 15: Taxas de câmbio nominais do USD e EUR em relação ao real (média de 2001 = 100).

A figura 16 mostra as variações entre o euro e o dólar. O euro apresenta uma trajetória de valorização em relação ao dólar a partir de 2002, interrompida entre o final de 2004 e o início de 2006. Daí até a crise financeira a moeda volta a valorizar-se ante o dólar. A partir da crise a relação entre as duas moedas fica mais irregular, com períodos mais curtos de valorização e desvalorização.

O objetivo principal das seções 5.1 e 5.2 é caracterizar a resposta dos preços de exportação às variações nas taxas de câmbio entre euro e real e entre o euro e o dólar. Com base na literatura e nas evidências das seção 4.3, espera-se rigidez elevada no curtíssimo prazo, com pass-through próximo de nulo na moeda de invoice. Em linha com a análise agregada em Gopinath et al (2010), espera-se que este pass-through aumente ao longo dos primeiros trimestres, mas que não seja completo mesmo em prazos maiores. 


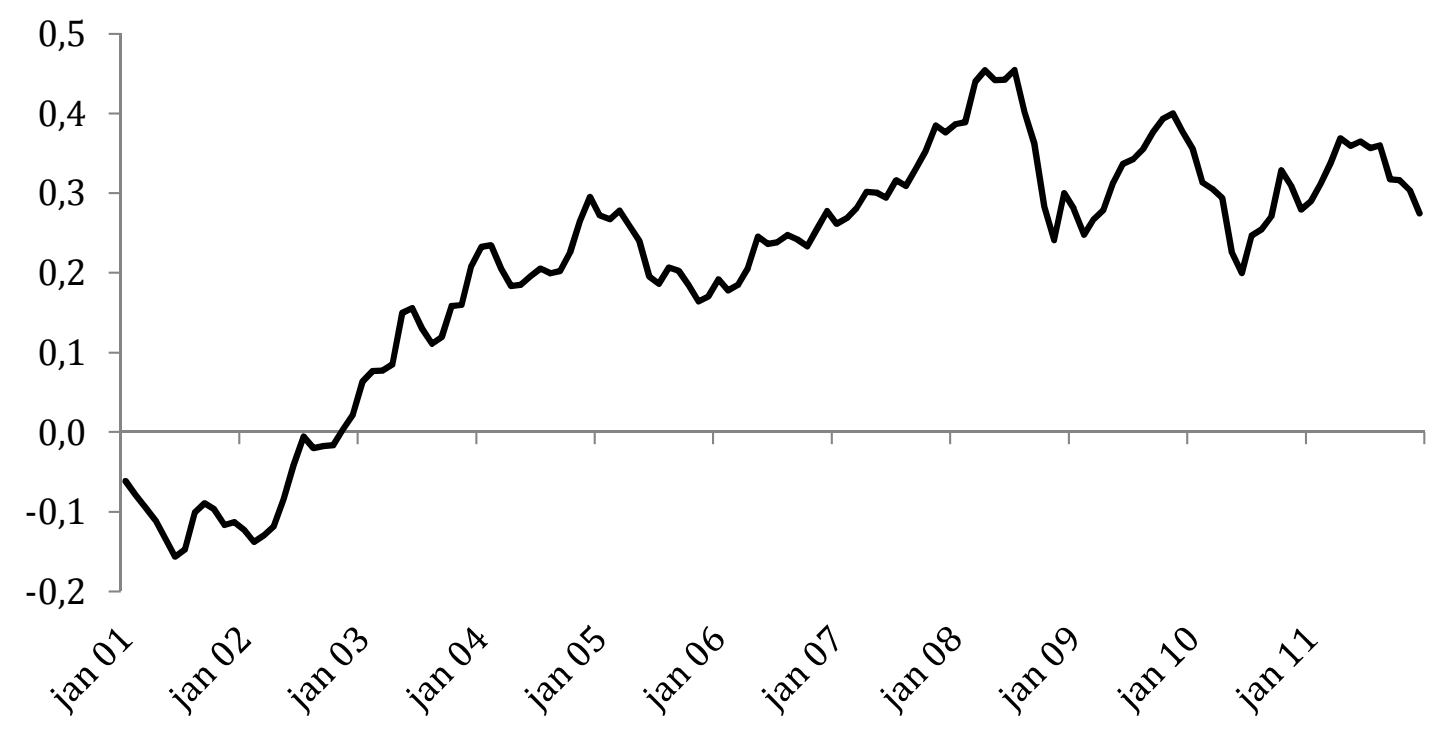

Figura 16: Razão entre as taxas de câmbio nominais do dólar e euro - $\log (\mathrm{USD} / \mathrm{EUR})$.

É importante observar que, principalmente para o médio e longo prazos, não é o objetivo da análise avaliar o impacto das variações de câmbio sobre a rentabilidade das firmas exportadoras no Brasil. Para isto seria necessário controlar, direta ou indiretamente, as variações de custo da firma exportadora no período. O objetivo da análise é caracterizar as diferenças entre as exportações que utilizam o euro e o dólar, em linha com os artigos de Fabling e Sanderson (2013) e Gopinath et al (2010). A persistência das diferenças de passthrough, mesmo no longo prazo, contribuem para o argumento de determinação endógena da moeda de invoice.

\subsection{REGRESSÃO AGREGADA}

Esta seção segue a proposta de Gopinath et al (2010) para estimar a resposta dinâmica dos preços de exportação a variações no câmbio, com ênfase na diferença entre exportações com invoice em euro e dólar. Os autores constroem índices de preço agregados a partir das séries de preço do BLS, e em seguida estimam uma equação dinâmica em que a variável explicada é a variação mensal do índice de preços e as variáveis explicativas de interesse são a variação contemporânea da taxa de câmbio bilateral e suas defasagens. Utilizam como controle a variação do índice de preços ao produtor do país de origem do bem e a variação do PIB americano. Gopinath et al (2010) constroem índices específicos para importações na moeda local (USD) e na moeda do país exportador. O objetivo da análise é ilustrar a diferença 
na resposta dinâmica dos dois índices a variações na taxa de câmbio bilateral entre os dois países.

A análise nessa seção segue estratégia similar. A seção 5.1.1 discute a construção dos índices de preço agregados e a seção 5.1.2 apresenta a estimação dos modelos dinâmicos de pass-through para os preços de exportação.

Os índices são construídos a partir da amostra de operações de exportação para países selecionados da União Europeia que também façam parte da Zona do Euro, de forma que seja possível identificar o euro como a moeda local do importador. A amostra também é restrita a bens diferenciados, por duas razões. Em primeiro lugar, a heterogeneidade na moeda de invoice é maior para esse grupo de produtos, conforme resultados descritivos na seção 3 . Adicionalmente, para o caso da exportação brasileira de bens homogêneos (i.e commodities), a relação entre preços e câmbio pode envolver dinâmica mais complexa. Conforme Chen e Rogoff (2002), a taxa de câmbio de países exportadores de bens primários responde a variações no preço dos bens primários exportados.

\subsubsection{CONSTRUÇÃO DOS ÍNDICES DE PREÇO AGREGADOS}

Gopinath et al (2010) não oferecem detalhes sobre a construção dos índices agregados de preço que utilizam na sua estimação. Aparentemente a variação mensal do índice é simplesmente a média aritmética, não ponderada, das variações mensais de cada um dos produtos na amostra do BLS. Não é claro, porém, o tratamento dado a mercadorias que não apresentem preços válidos em dois meses consecutivos. Os autores indicam que consideram como válidos apenas preços efetivamente associados a uma transação e que não tenham sido realizados entre firmas do mesmo grupo. A especificação do tratamento de períodos sem transações de uma mercadoria é relevante, dado que é comum nas exportações registradas no Siscomex que a mercadoria não seja transacionada em meses consecutivos.

Esta seção apresenta três estratégias adotadas para a construção de índices de preço para os dados de exportação do Siscomex. Da mesma forma que nas seções anteriores, a agregação é baseada na identificação de uma mercadoria como um trio NCM-Firma-Destino. As três estratégias têm como princípio não restringir o cálculo apenas às mercadorias que são transacionadas em meses consecutivos. 
O primeiro passo das três estratégias é a agregação mensal das operações de uma mesma mercadoria em cada moeda de invoice. A agregação é realizada somando o valor e o peso das operações individuais. O valor unitário da mercadoria no mês é então obtido como a razão do valor da mercadoria no mês por seu peso no mês. Este critério de agregação mensal dá maior peso ao valor unitário de operações maiores. Por simplicidade, no restante desta seção, o termo preço é utilizado no lugar de valor unitário.

A primeira estratégia segue Gopinath et al (2010) e calcula a variação do índice de preços no mês como uma média aritmética, não ponderada, das variações entre o próprio mês e o meses anteriores. Este índice é essencialmente um índice de Carli encadeado, modificado de forma a incorporar a variação de preço de mercadorias que não são transacionadas em meses consecutivos ${ }^{28}$. $\mathrm{O}$ índice é calculado segundo os passos abaixo.

1) Para toda exportação consecutiva de uma mercadoria que ocorra na mesma moeda de invoice, é calculada a variação de preço na moeda de invoice. As exportações não precisam ocorrer em meses consecutivos.

2) O primeiro mês da amostra (janeiro de 2001) é definido como tendo o nível de preço 100.

3) Para calcular o nível do mês seguinte, são utilizadas todas as variações de preço entre o mês e todos os meses anteriores (obtidas no passo 1). Cada variação de preço define um nível para o mês atual sendo calculado.

4) O nível agregado do mês é obtido como uma média aritmética dos níveis definidos por cada mercadoria. As caudas da distribuição são eliminadas antes do cálculo da média.

5) Os passos 3 e 4 são então repetidos para os meses seguintes, iterativamente.

Foram consideradas apenas mercadorias em que o espaço de tempo entre a primeira e a última exportação na mesma moeda tenha sido de pelo menos 18 meses, de forma a manter na amostra somente mercadorias para as quais seja possível observar seu comportamento tanto de curto, quanto de médio prazo.

${ }^{28}$ O "Export and Import Price Index Manual" do Fundo Monetário Internacional, IMF (2009), traz uma discussão compreensiva sobre a construção de índices de preço para o comércio internacional, em especial sobre o uso de valores unitários, e sobre as várias fórmulas de agregação. 
A eliminação das caudas da distribuição de cada mês foi realizada de forma a reduzir a influência da heterogeneidade dentro de um mesmo trio NCM-Firma-Destino, conforme a discussão da seção 4.1 .

As figuras 17 e 18 abaixo ilustram, para cada moeda, os índices agregados obtidos com a exclusão de $15 \%, 20 \%$, e $25 \%$ de cada cauda ${ }^{29}$. Como as figuras indicam, a evolução de longo prazo dos índices mostrou-se sensível a este critério. As respostas de curto prazo, no entanto, são muito similares para as curvas em cada moeda.

A sensibilidade do índice à exclusão das caudas é característica do índice de Carli. Conforme IMF (2009), este tipo de índice apresenta viés positivo em relação a outros índices elementares, crescente com a dispersão das variações de preço utilizadas na agregação. Dada a heterogeneidade nos valores unitários da mesma mercadoria, conforme resultados da seção 4.1, a dispersão das variações na amostra é elevada. Apesar de não indicadas nas figuras 17 e 18, as séries obtidas com a exclusão de frações menores das caudas (5\% ou 10\%) resulta em índices com tendência positiva muito forte. De fato, os índices obtidos com a exclusão de $15 \%, 10 \%$ e $5 \%$ das caudas possuem valor final 59\%, $187 \%$ e $1259 \%$ maiores do que o índice obtido com exclusão de $25 \%$ das caudas.

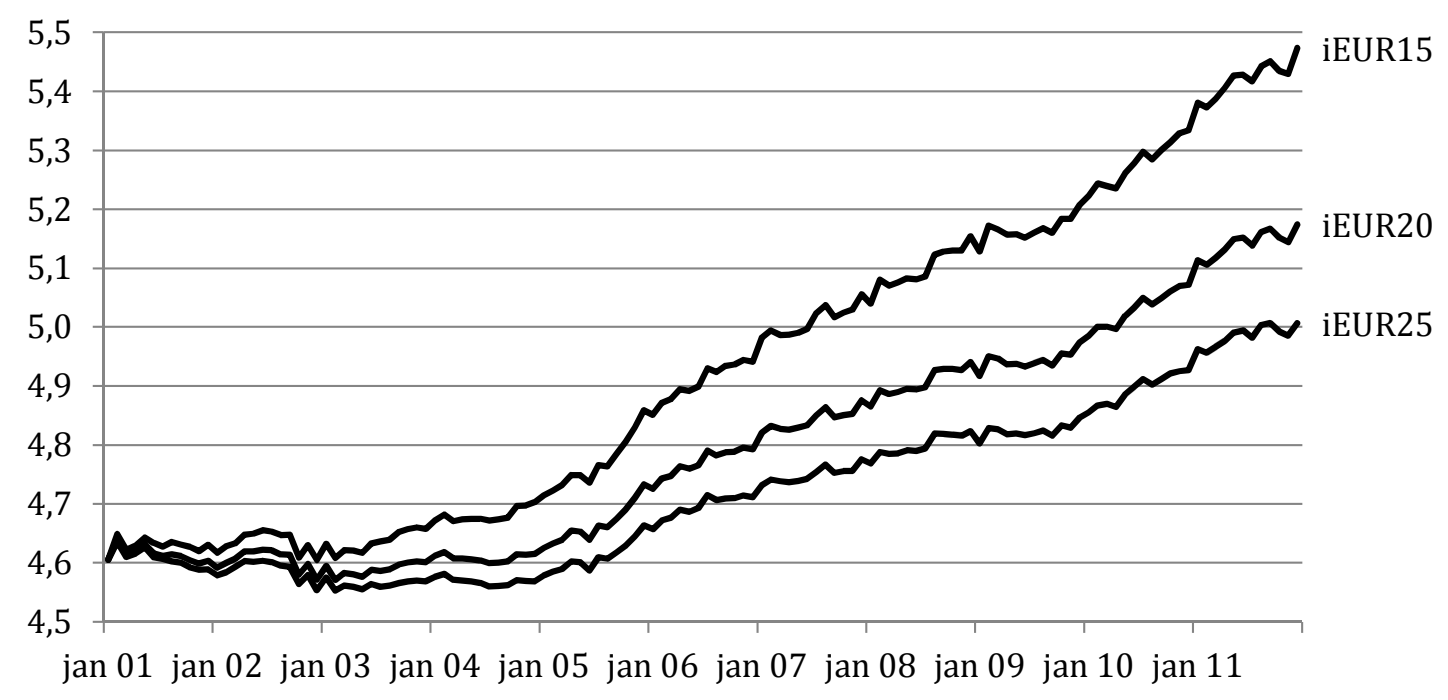

Figura 17: Índices de preço de exportações com invoice em EUR (log) - Estratégia 1.

${ }^{29}$ A razão média entre o topo e o piso das bandas de exclusão para os critérios de $15 \%, 20 \%$ e $25 \%$ foram 2,0, 1,6, e 1,3 para o índice em euro, e 2,2, 1,7, e 1,4 para o índice em dólar. 


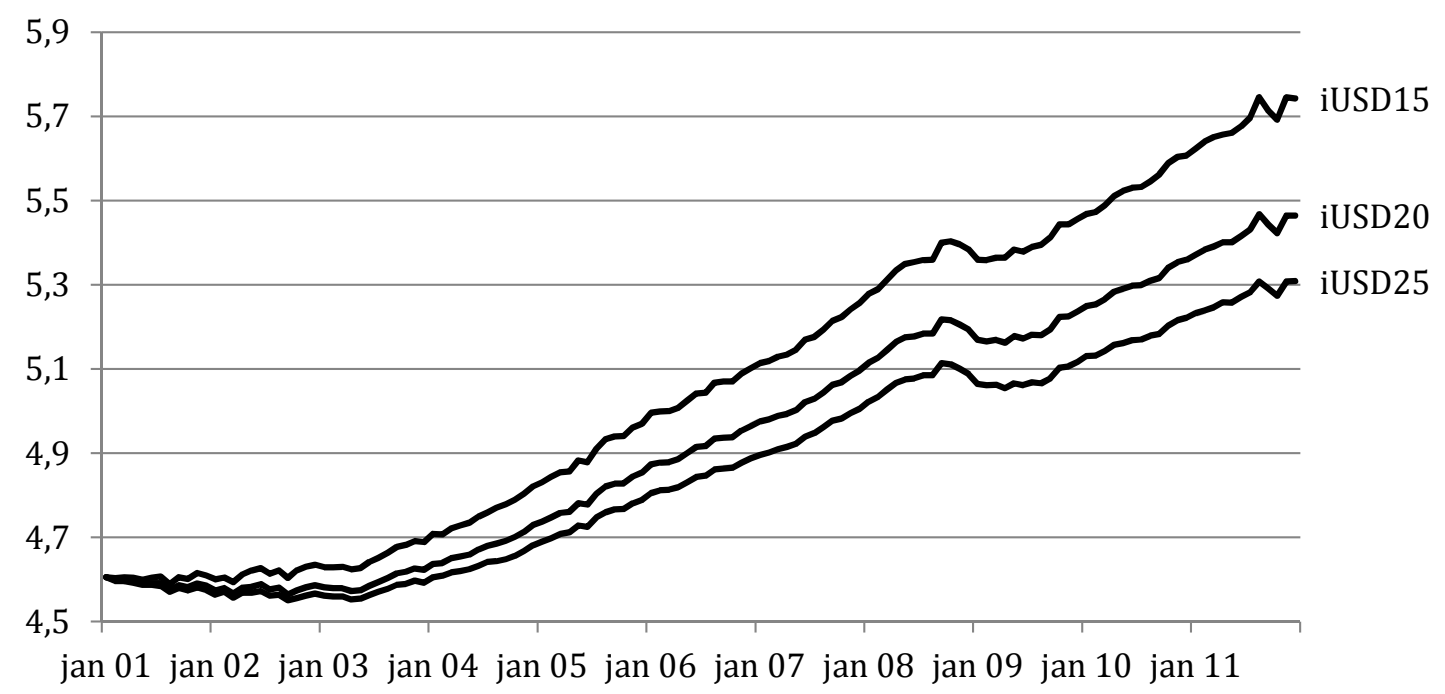

Figura 18: Índices de preço de exportações com invoice em USD (log) - Estratégia 1.

A segunda estratégia segue a fórmula do índice de Jevons, conforme IMF (2009), e calcula a variação do índice de preços no mês como a média geométrica das variações entre o próprio mês e os meses anteriores. O cálculo é modificado em relação à fórmula básica apresentada em IMF (2009) de forma a incorporar a variação de preço de mercadorias que não são transacionadas em meses consecutivos. Os passos são similares àqueles da estratégia um, com a diferença da média utilizada.

1) Para toda exportação consecutiva de uma mercadoria que ocorra na mesma moeda de invoice, é calculada a variação de preço na moeda de invoice. As exportações não precisam ocorrer em meses consecutivos.

2) O primeiro mês da amostra (janeiro de 2001) é definido como tendo o nível de preço 100.

3) Para calcular o nível do mês seguinte, são utilizadas todas as variações de preço entre o mês e todos os meses anteriores (obtidas no passo 1). Cada variação de preço define um nível para o mês atual sendo calculado.

4) O nível agregado do mês é obtido como uma média geométrica dos níveis definidos por cada mercadoria. As caudas da distribuição são eliminadas antes do cálculo da média.

5) Os passos 3 e 4 são então repetidos para os meses seguintes, iterativamente. 
As figuras 19 e 20 abaixo ilustram, para cada moeda, os índices agregados obtidos para a exclusão de $5 \%, 15 \%$, e $25 \%$ de cada cauda ${ }^{30}$. Ao contrário dos índices obtidos seguindo a fórmula de Carli, a evolução de longo prazo dos índices é pouco sensível ao critério de exclusão das caudas.

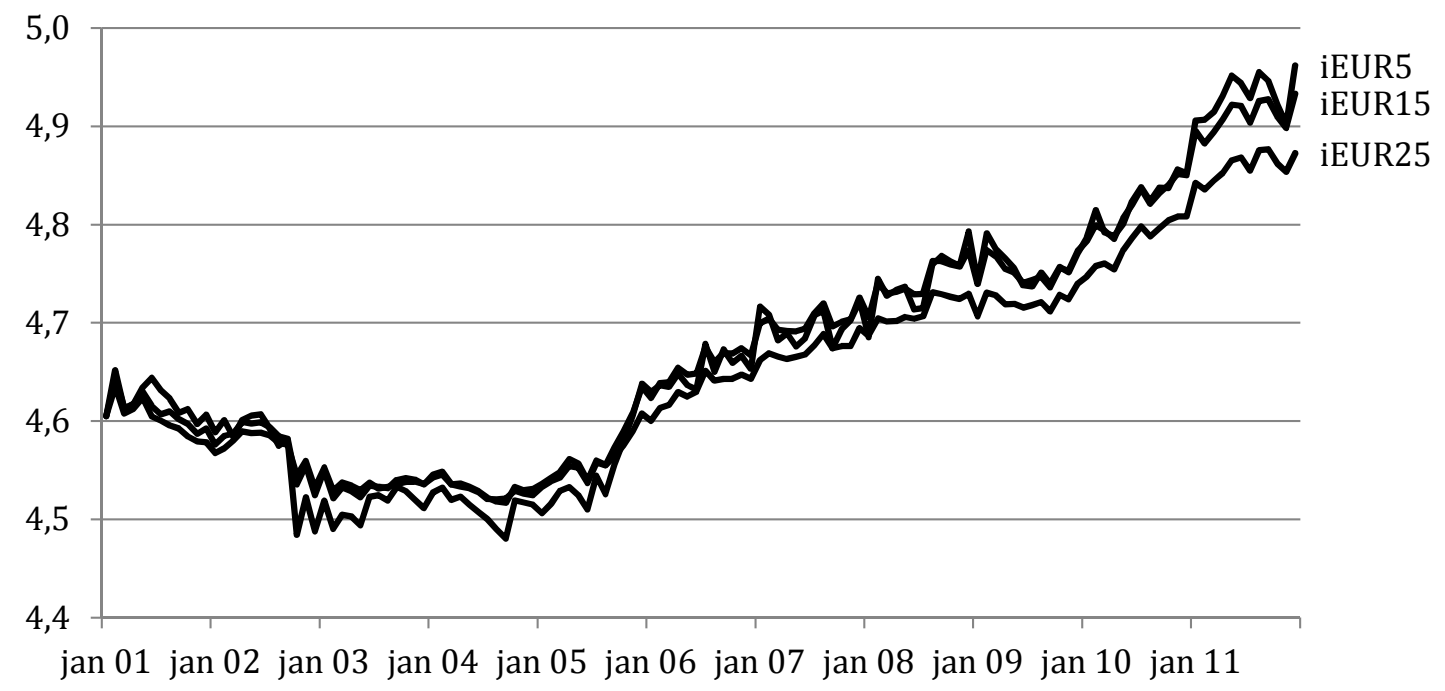

Figura 19: Índices de preço de exportações com invoice em EUR (log) - estratégia 2.

${ }^{30}$ A razão média entre o topo e o piso das bandas de exclusão para os critérios de 5\%, $15 \%$ e $25 \%$ foram 8,3, 2,0, e 1,3 para o índice em euro, e 11,7, 2,2, e 1,4 para o índice em dólar. 


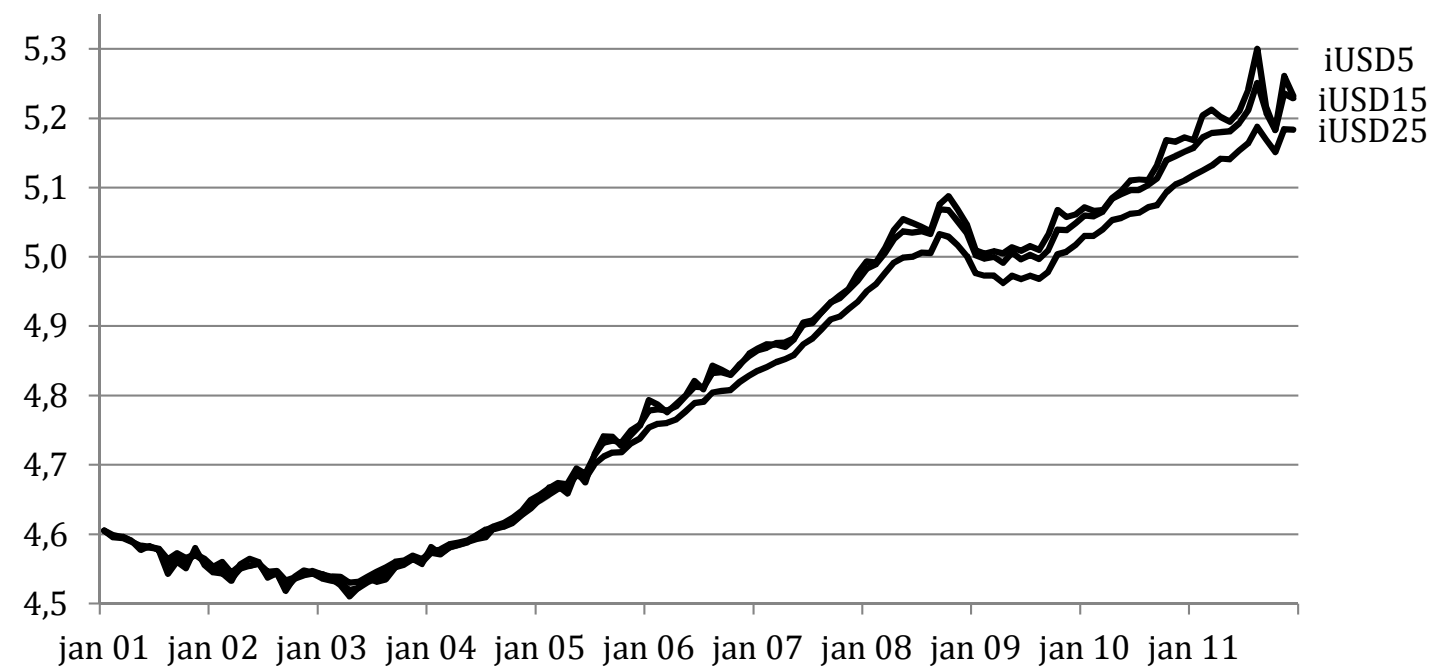

Figura 20: Índices de preço de exportações com invoice em USD (log) - estratégia 2.

A terceira estratégia segue mais de perto o método que a Funcex utiliza para a construção dos índices de preço de exportação por segmento, de acordo com Guimarães et al (1997). O procedimento é descrito a seguir.

1) Para cada mercadoria, a moeda de invoice predominante em cada ano é definida como aquela na qual pelo menos $95 \%$ das transações do ano tenham sido realizadas (em valor).

2) Apenas anos consecutivos na mesma moeda predominante são considerados para cada mercadoria.

3) O primeiro ano da amostra (2001) é definido como ano base e recebe o valor de 100 em todos os meses.

4) Para cada mês do ano seguinte, calcula-se a variação do preço de cada mercadoria transacionada no mês contra a média do seu preço no ano anterior.

5) As caudas dessas variações são eliminadas, e calcula-se a média das variações restantes. O índice agregado do mês é obtido multiplicando esta variação média pela média do próprio índice no ano anterior.

6) Após a definição de todos os meses do ano, calcula-se o índice no ano seguinte repetindo os passos 4 e 5 .

Ao contrário do método utilizado pela Funcex, a média das variações não foi ponderada por qualquer critério de valor. 
As figuras 21 e 22 abaixo ilustram, para cada moeda, os índices agregados obtidos para a exclusão de $15 \%, 20 \%$, e $25 \%$ de cada cauda ${ }^{31}$. Também foi incluído o índice obtido a partir da mediana das variações em cada mês. A evolução de longo prazo dos índices mostrou-se sensível ao critério de exclusão das caudas. Os índices obtidos com a exclusão de 15\%, 10\% e $5 \%$ das caudas possuem valor final 17\%, 39\% e 108\% maiores do que o índice obtido com exclusão de $25 \%$ das caudas. No entanto, como nos índices obtidos segundo a fórmula de Carli, as respostas de curto prazo são muito similares entre as curvas em cada moeda. Uma desvantagem desta estratégia é a perda do primeiro ano da amostra (2001), para o qual só é conhecida a média anual.

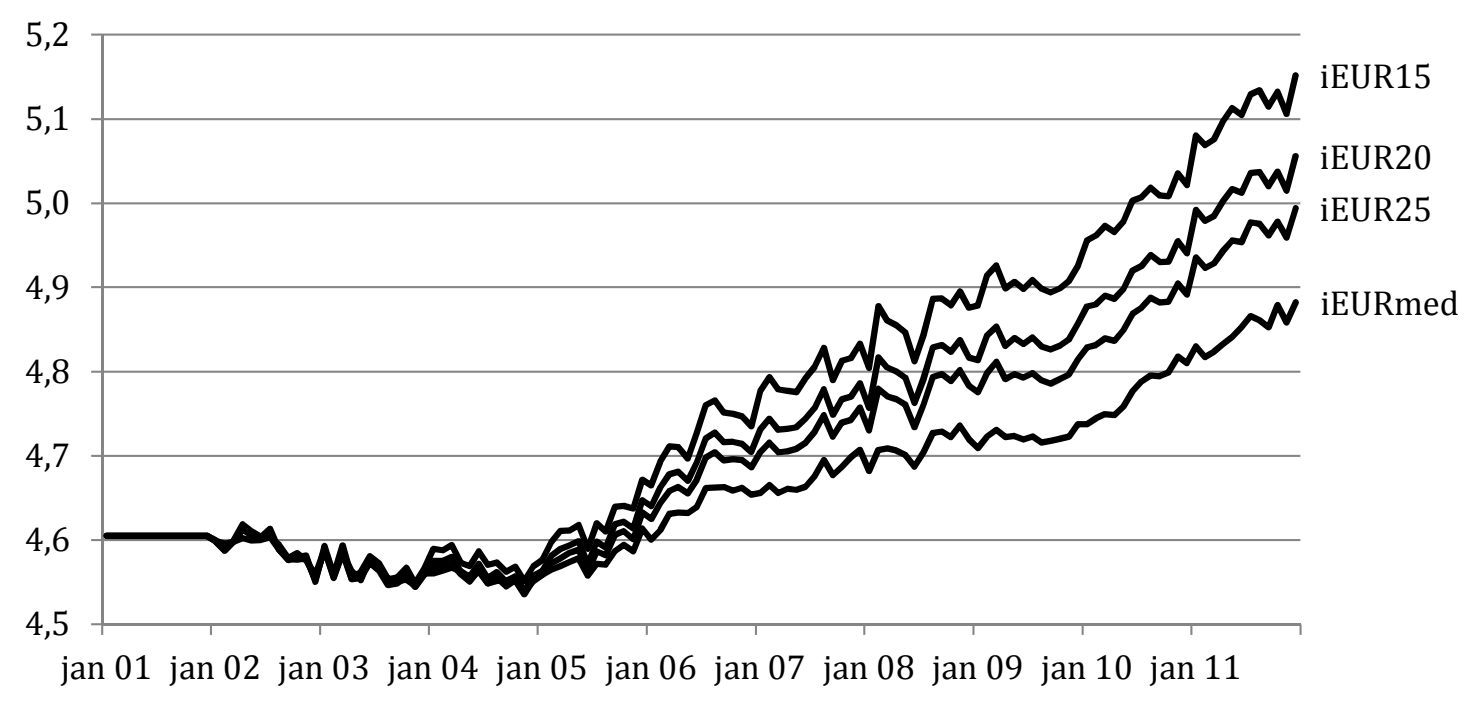

Figura 21: Índices de preço de exportações com invoice em EUR (log) - estratégia 3.

${ }^{31}$ A razão média entre o topo e o piso das bandas de exclusão para os critérios de $15 \%, 20 \%$ e $25 \%$ foram 2,1, 1,7, e 1,4 para o índice em euro, e 2,3, 1,8, e 1,5 para o índice em dólar. 


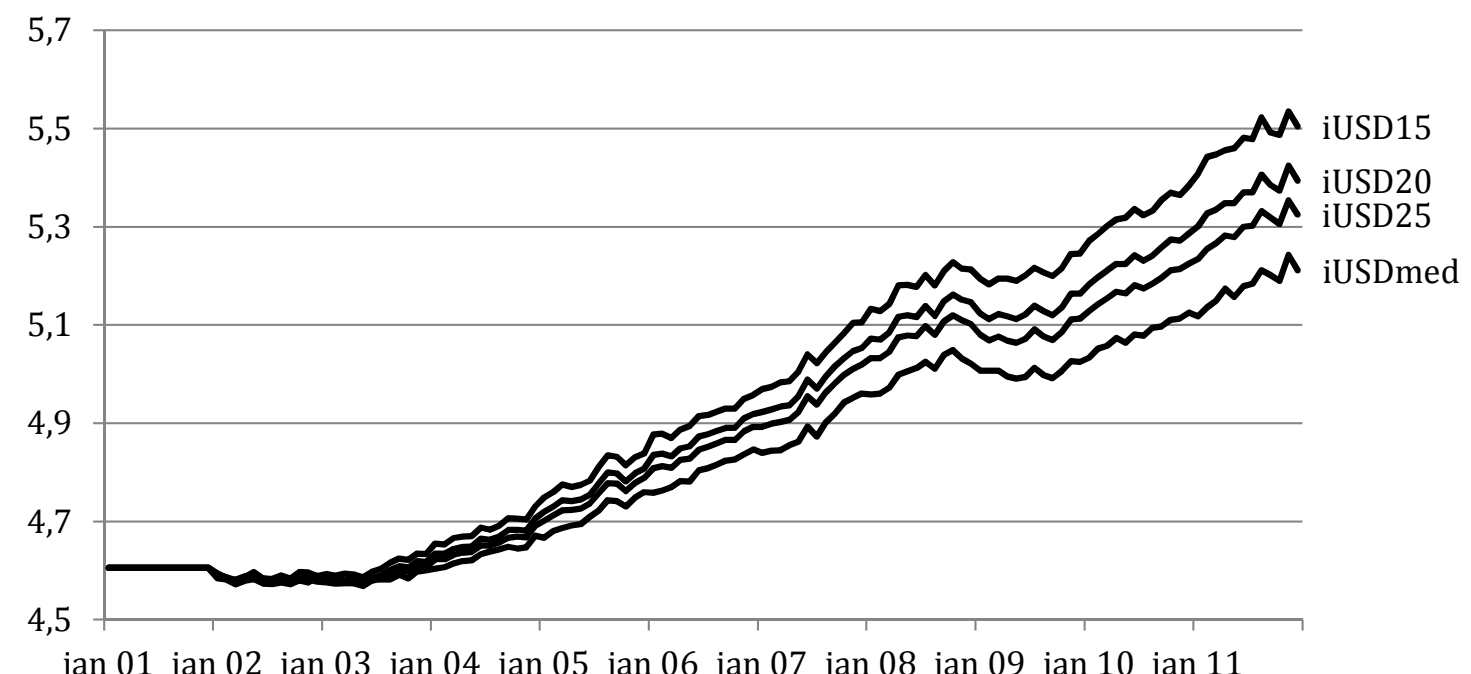

jan 01 jan 02 jan 03 jan 04 jan 05 jan 06 jan 07 jan 08 jan 09 jan 10 jan 11

Figura 22: Índices de preço de exportações com invoice em USD (log) - estratégia 3.

A análise na seção 5.1.2 é motivada pela comparação dos índices de preço para invoice em euro (iEUR) e em dólar (iUSD). A figura 23 abaixo compara o índice iEUR25.2 com o índice iUSD25.2, ambos calculados de acordo com a estratégia 2, com a exclusão de $25 \%$ de cada cauda. O índice iEUR25.2 foi convertido em dólar pela taxa de câmbio média de cada mês. O padrão da evolução relativa entre os dois índices de preço fica mais claro na figura seguinte, que compara a razão entre os índices com a evolução da taxa de câmbio USD/EUR.

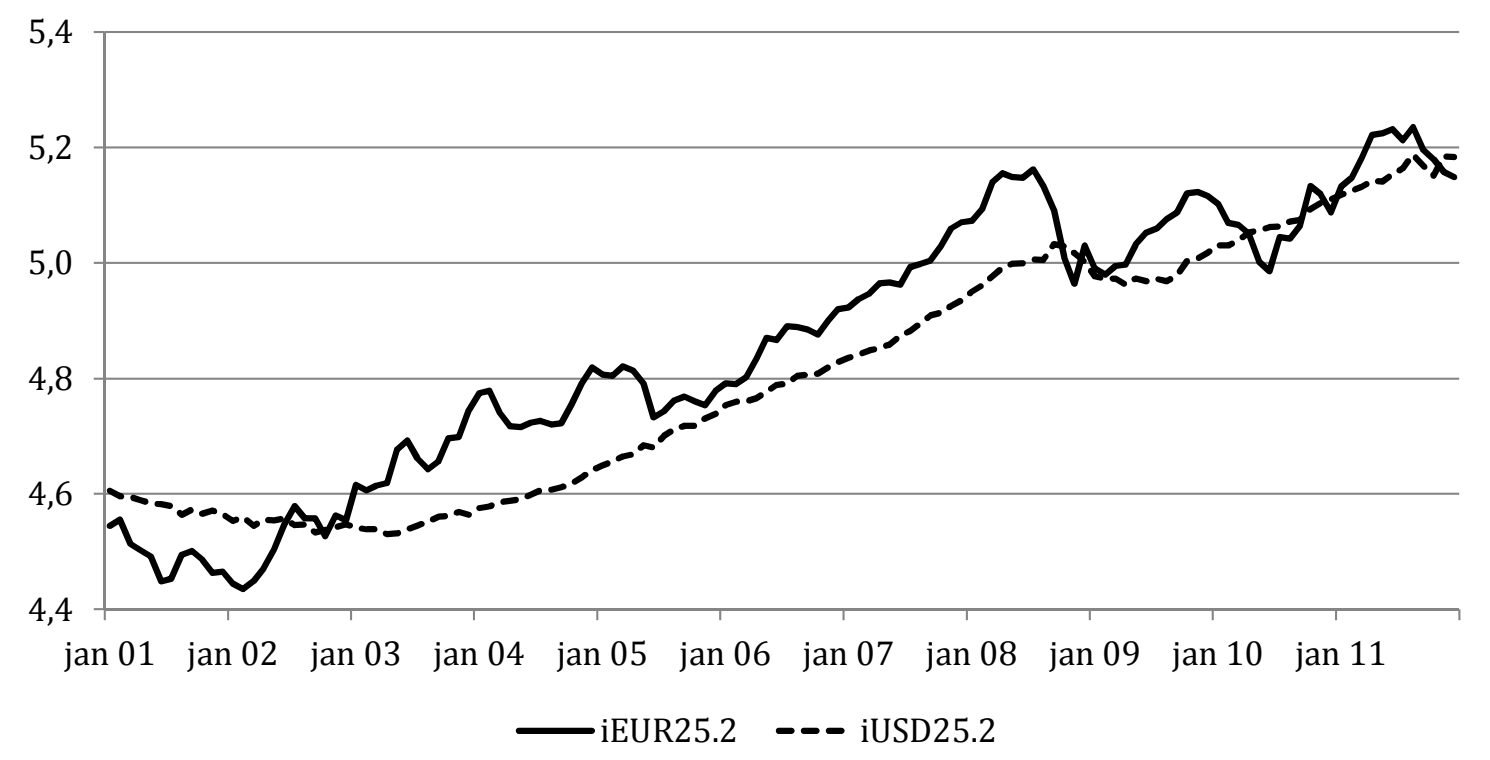

Figura 23: Índices de preço de exportação para invoice em EUR e USD - estratégia 2, exclusão de $25 \%$ das caudas. Índice iEUR25.2 convertido em dólar pela taxa média do mês. 


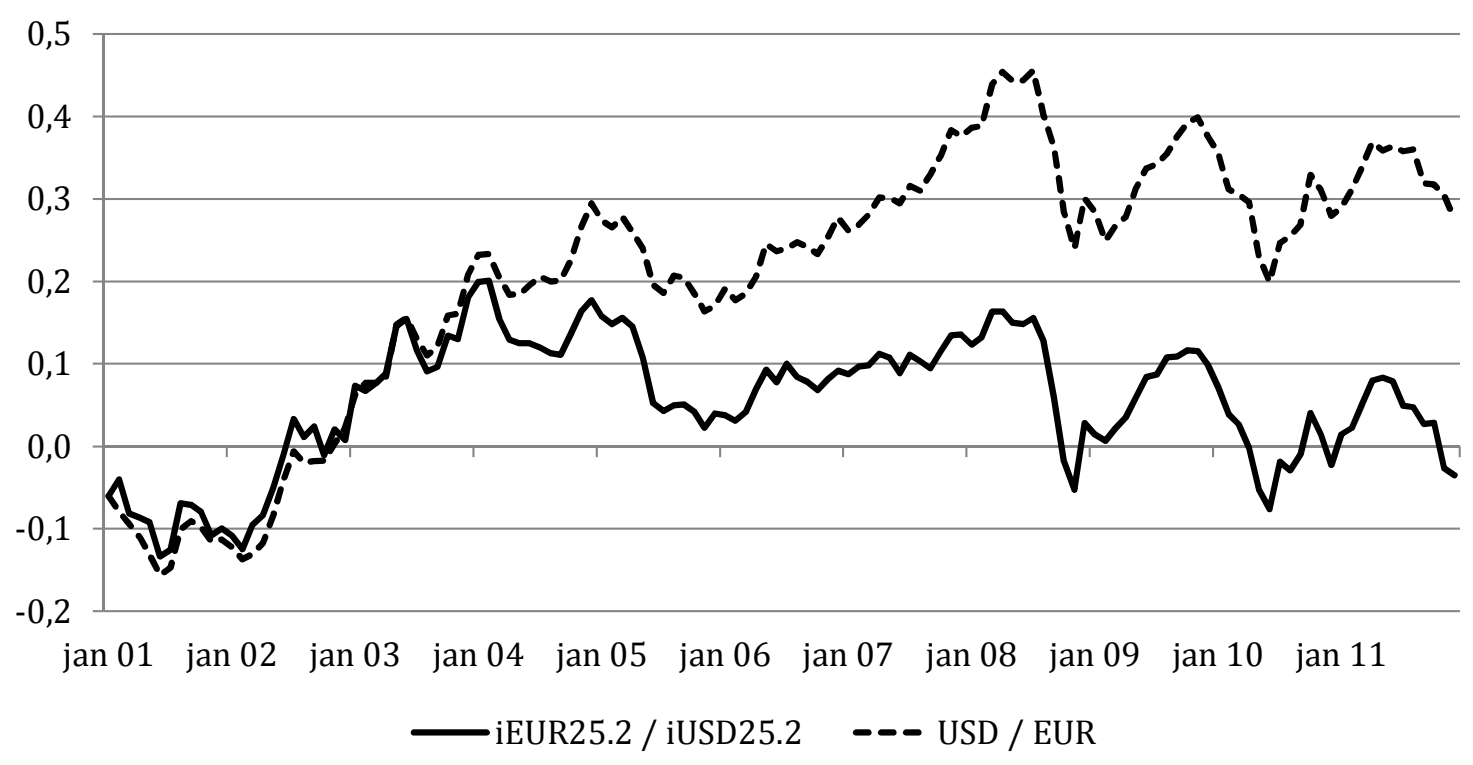

Figura 24: Razão entre os índices de preço (em euro) e a taxa de câmbio USD/EUR estratégia 2, exclusão de $25 \%$ das caudas, ambas as curvas em logaritmo.

A figura 24 sugere que a variação relativa entre os índices segue a variação na taxa de câmbio entre as duas moedas, pelo menos no curto e médio prazos. Assim, nas exportações para a União Europeia, o preço relativo das mercadorias exportadas em dólar em relação àquelas exportadas em euro parece associado a variações na taxa de câmbio entre as duas moedas.

As figuras 25 e 26 repetem o exercício da figura 24 para os índices calculados pelas estratégias 1 e 3 , ambos com o critério de exclusão de cauda de $25 \%$. O padrão observado é basicamente o mesmo, apesar de parecer mais fraco no caso dos índices obtidos através da estratégia 3.

A seção 5.1.2 utiliza como referência os índices obtidos através da estratégias 1 e 2, com o critério de exclusão de $25 \%$ das caudas. Este último critério resulta em índices para invoice em USD que possuem variação de longo prazo mais próxima àquela do índice de preços de exportação de bens manufaturados da Funcex. Por outro lado, como sugere a figura 26, os índices obtidos através da estratégia 3 levam em geral a resultados mais fracos do que aqueles encontrados com os índices obtidos através das estratégias 1 e 2. 


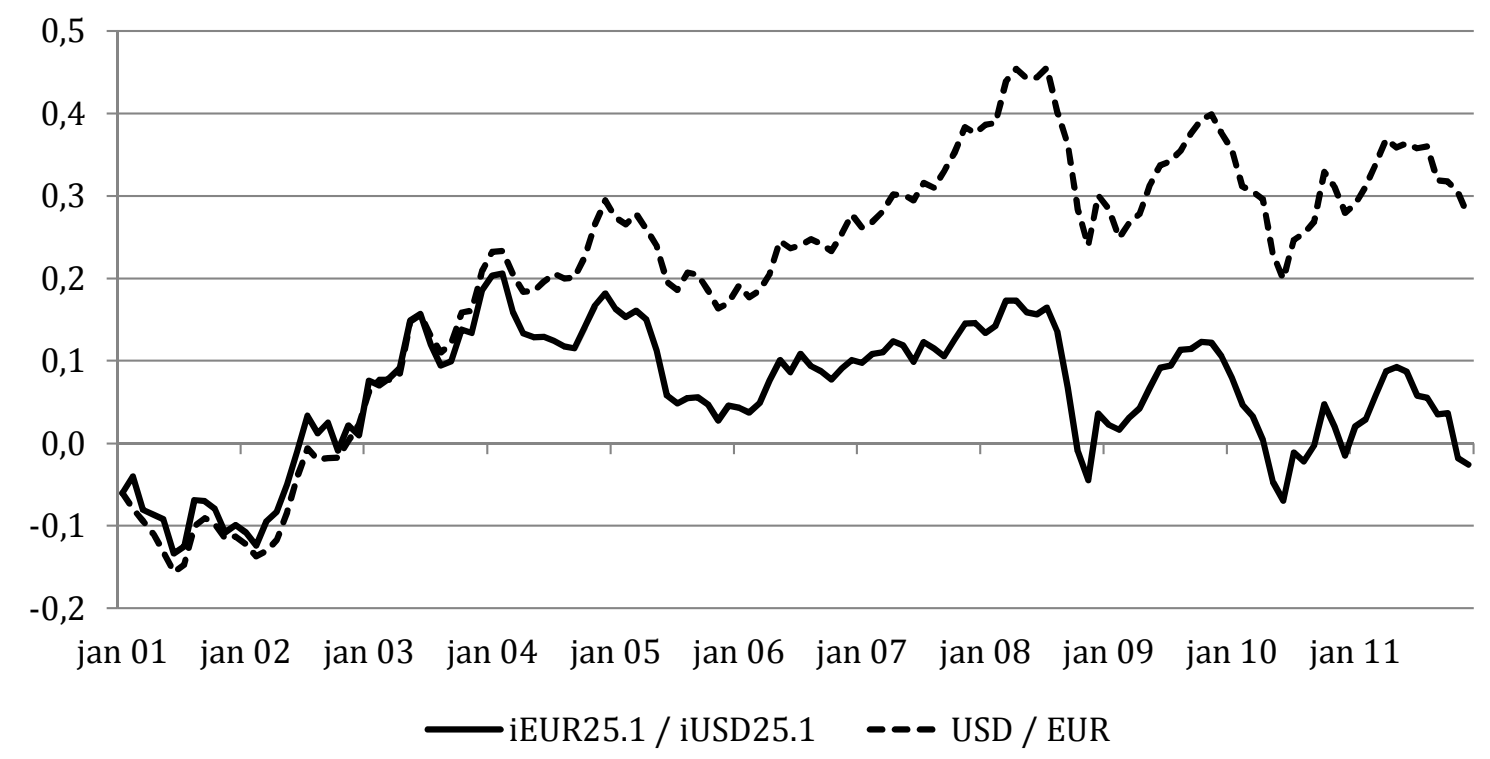

Figura 25: Razão entre os índices de preço (em euro) e a taxa de câmbio USD/EUR estratégia 1, exclusão de $25 \%$ das caudas, ambas as curvas em logaritmo.

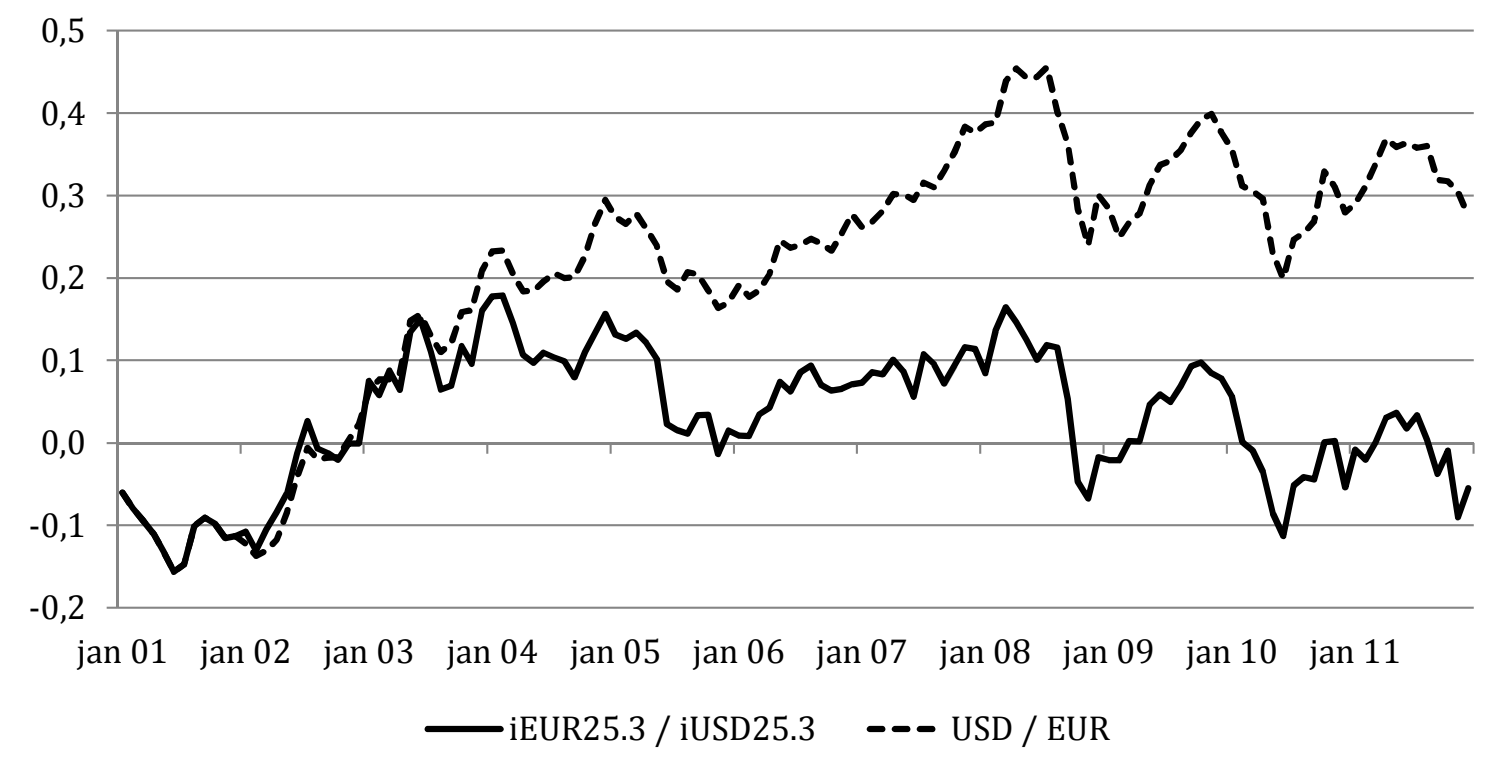

Figura 26: Razão entre os índices de preço (em euro) e a taxa de câmbio USD/EUR estratégia 3, exclusão de $25 \%$ das caudas, ambas as curvas em logaritmo.

É interessante notar, na figura 23, que os índices de preço para exportações em euro e em dólar parecem convergir para uma trajetória comum no longo prazo. Essa convergência pode ser interpretada como evidência de que, no longo prazo, o pass-through para exportações em euro e em dólar é o mesmo, ao menos neste nível de agregação. 


\subsubsection{ESTIMATIVA DA RESPOSTA DINÂMICA DOS PREÇOS DE EXPORTAÇÃO NO CURTO E MÉDIO PRAZO}

Seguindo o exercício proposto por Gopinath et al (2010), esta seção estima modelos dinâmicos para a resposta dos preços agregados de exportação a variações no câmbio.

De forma a facilitar a exposição dos resultados, os índices agregados calculados na seção 5.1.1 serão referenciados de acordo com a moeda de invoice, o método utilizado no cálculo do índice, e o percentual de variações extremas excluídos de cada cauda. Assim, "iEURm2x05" indica o índice de preço de exportações com invoice em EUR, calculado de acordo com a estratégia 2, e com a exclusão de 5\% das caudas. Da mesma forma, “iUSDm1x25" indica o índice de preço de exportações com invoice em USD, calculado de acordo com a estratégia 1, e com a exclusão de $25 \%$ das caudas. Todos os índices foram convertidos em euro, de acordo com a taxa de câmbio média de cada mês. Como referência para a discussão dos resultados, foram utilizados os índices iEURm2x25 e iUSDm2x25, obtidos com a estratégia 2, e exclusão de $25 \%$ das caudas. A estratégia 2 foi preferida em função da sua insensibilidade, no longo prazo, ao critério de exclusão das variações extremas.

Para o índice de preço de exportações com invoice em euro, o modelo dinâmico utilizado é dado pela equação 3 , em que $\Delta p_{t}$ é a variação no log do índice de preço, e $\Delta e_{t}$ é a variação no log do câmbio nominal, em reais por euro. O índice de preços é dado em euros, conforme a seção anterior.

\section{Equação 3}

$$
\Delta p_{t}=\alpha+\sum_{j=0}^{n} \beta \cdot \Delta e_{t-j}+\varepsilon_{t}
$$

Na equação acima, a estatística de interesse são os valores acumulados do coeficiente de pass-through $\beta$. Valores próximos de zero indicam que o índice responde pouco a variações no câmbio bilateral, o que equivale à precificação das mercadorias em euro (moeda do importador). Valores próximos a menos um indicam que o índice responde totalmente a variações no câmbio bilateral, o que equivale à precificação das mercadorias em real (moeda da firma exportadora brasileira). 
A figura 27 abaixo mostra o resultado da estimação da equação 3 para o índice iEURm $2 \times 25$. Os coeficientes são apresentados na forma do pass-through $\beta$ acumulado, em conjunto com o intervalo de confiança de $95 \%$. No curto prazo, a estimativa pontual do passthrough é muito próxima de zero, e atinge 35\% após 24 meses, em linha com os resultados obtidos por Gopinath et al (2010) para importações americanas em moeda local. Assim, de acordo com a estimativa pontual, uma apreciação de $10 \%$ do real frente ao euro está associada, no médio prazo, a uma alta de 3,5\% no preço das exportações que utilizam o euro como moeda de invoice.

A figura 28 repete o exercício para os índices obtidos através das estratégias 1 e 3, ambos com exclusão de $25 \%$ das caudas, e através da estratégias 2, com exclusão de $15 \%$ e 5\% das caudas. Em todos os casos, o pass-through acumulado no curtíssimo prazo é próximo de zero, e cresce ao longo dos meses.

Para o índice iEURm1x25, os resultados são muito similares àquele obtido com o índice de referência. Após 24 meses, o pass-through acumulado atinge 35\%.

Para os índices iEURm2x15 e iEURm2x05, ambos obtidos com a estratégia 2, a estimativa pontual para o pass-through acumulado em 24 meses é de $39 \%$ e 44\%, respectivamente. Apesar de a estimativa variar pouco, o erro padrão dos coeficientes estimados é maior do que para o índice de referência.

A regressão que utiliza o índice obtido pela estratégia 3 e exclusão de $25 \%$ das caudas gera uma estimativa pontual do pass-through acumulado maior, de 53\% após 24 meses, com erro padrão mais elevado. 


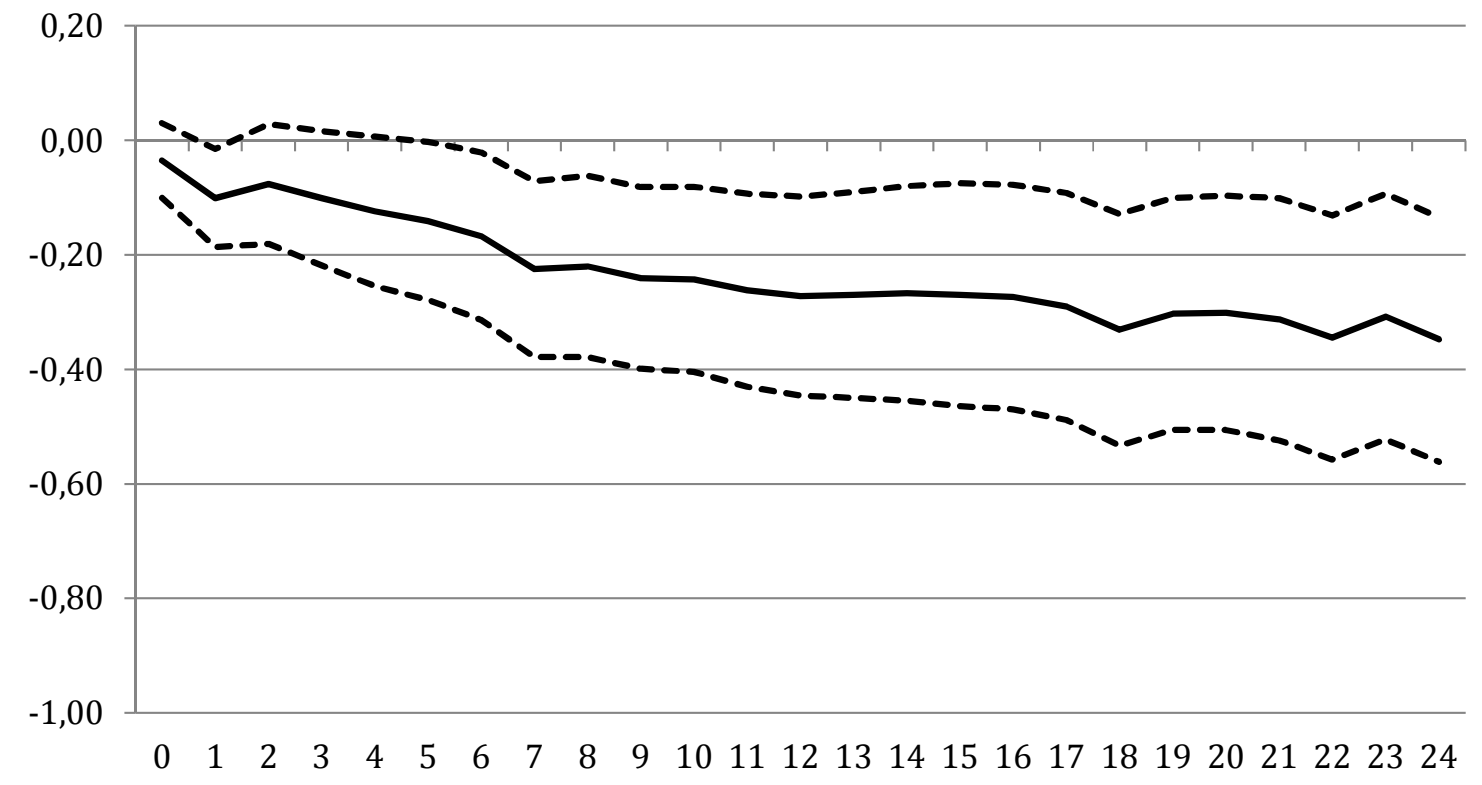

Figura 27: Pass-through de variações na taxa EUR/BRL para o preço de exportações com invoice em EUR - índice iEURm2x25. 


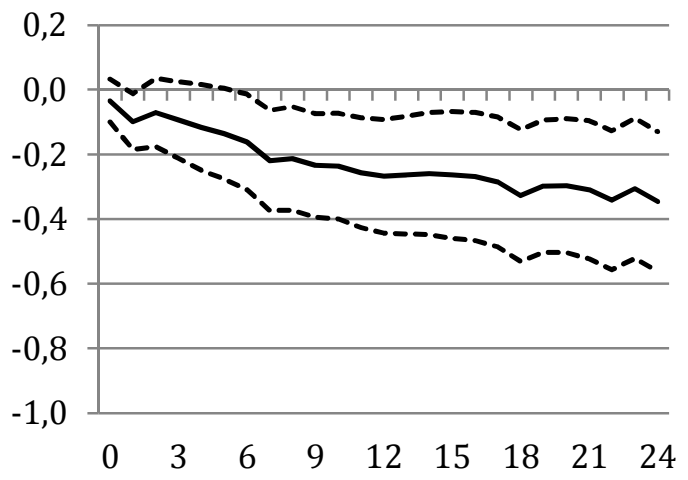

(a) iEURm1 125

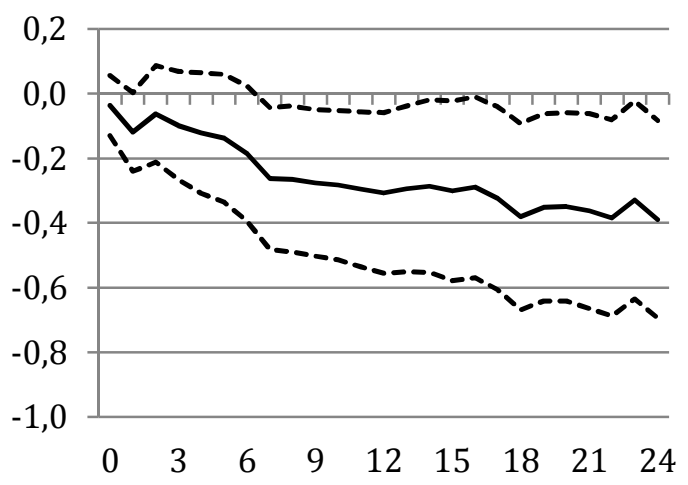

(c) iEURm $2 \times 15$

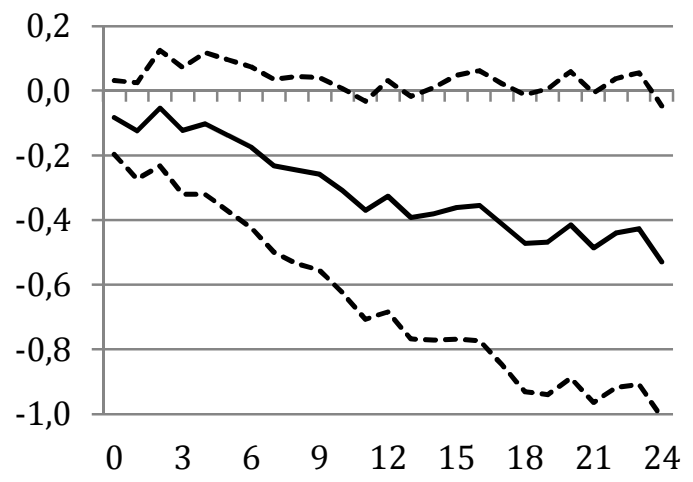

(b) iEURm3x25

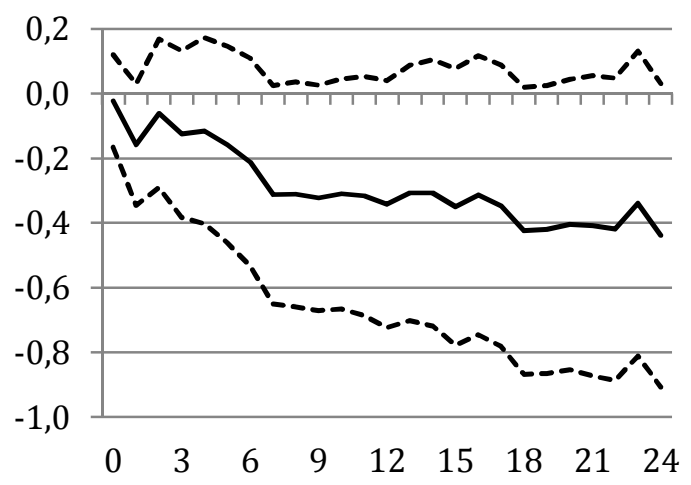

(d) iEURm2x05

Figura 28: Pass-through de variações na taxa EUR/BRL para o preço de exportações com invoice em EUR. Índices utilizados são indicados abaixo de cada gráfico.

Para o índice de preço de exportações com invoice em dólar, a variação do câmbio bilateral BRL-EUR é decomposta na variação BRL-USD e USD-EUR, conforme proposta de Fabling e Sanderson (2013). O modelo dinâmico é dado pela equação 4, em que $\Delta e_{R / D, t}$ é a variação do câmbio entre o real e o dólar, e $\Delta e_{D / E, t}$ é a variação do câmbio entre o dólar e o euro; $\Delta p_{t}$ é variação do índice de preço convertido em euros.

\section{Equação 4}

$$
\Delta p_{t}=\alpha+\sum_{j=0}^{n} \beta_{R / D} \cdot \Delta e_{R / D, t-j}+\sum_{j=0}^{n} \beta_{D / E} \cdot \Delta e_{D / E, t-j}+\varepsilon_{t}
$$

A taxa de câmbio $e_{R / D, t}$ é dada em reais por dólar, e a taxa de câmbio $e_{D / E, t}$ é dada em dólares por euro. 
Na equação acima, a rigidez de preço em USD (moeda de invoice) seria equivalente a valores acumulados de $\beta_{R / D}$ próximos de zero e valores acumulados de $\beta_{D / E}$ próximos a menos um. A rigidez de preço em real (moeda do exportador) seria equivalente a valores acumulados de $\beta_{R / D}$ e de $\beta_{D / E}$ próximos de menos um. A rigidez de preço em euro (moeda do importador) seria equivalente a valores acumulados de $\beta_{R / D}$ e de $\beta_{D / E}$ próximos de zero.

As figuras 29 e 30 abaixo mostram o resultado da estimação da equação 4 para o índice iUSDm $2 \times 25$. A figura 29 apresenta o pass-through acumulado $\beta_{R / D}$, associado a variações na taxa de câmbio entre o real e o dólar; e a figura 30 apresenta o pass-through acumulado $\beta_{D / E}$, associado a variações na taxa de câmbio entre o dólar e o euro.

No curto prazo, a estimativa pontual do pass-through $\beta_{R / D}$ é muito próxima de zero, e atinge $39 \%$ após 24 meses. A estimativa do pass-through $\beta_{D / E}$, por outro lado, mantém-se próxima de $-90 \%$ ao longo de todo o período, e, em geral, não é diferente de -1 ao nível de significância de 95\%. O resultado, portanto, é consistente com a hipótese de rigidez dos preços na moeda de invoice (USD) no curto prazo. Variações na taxa de câmbio real-dólar são parcialmente compensadas ao longo do tempo, enquanto variações na taxa euro-dólar não são compensadas.

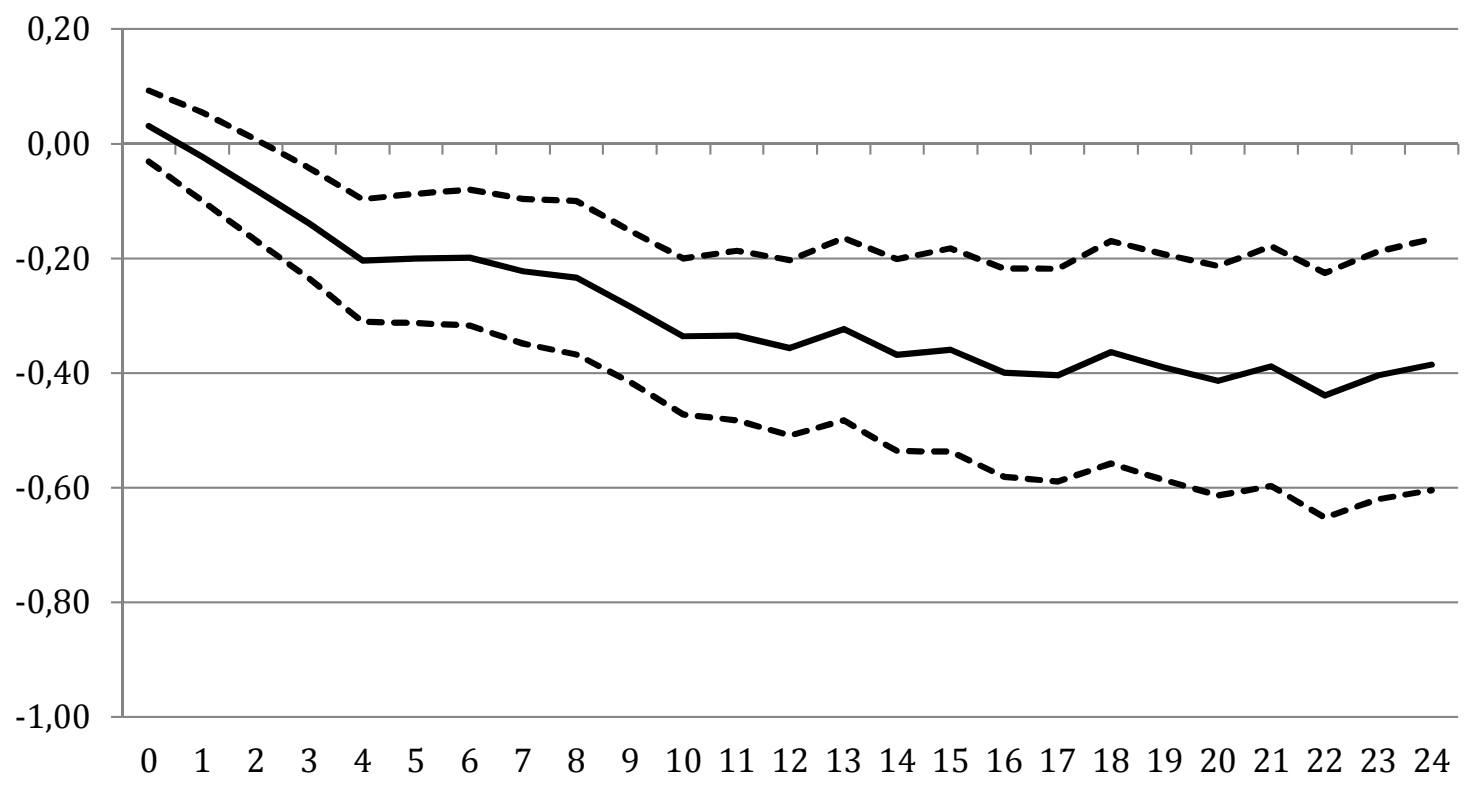

Figura 29: Pass-through de variações na taxa dólar-real para o preço de exportações com invoice em USD - índice iUSDm2x25. 


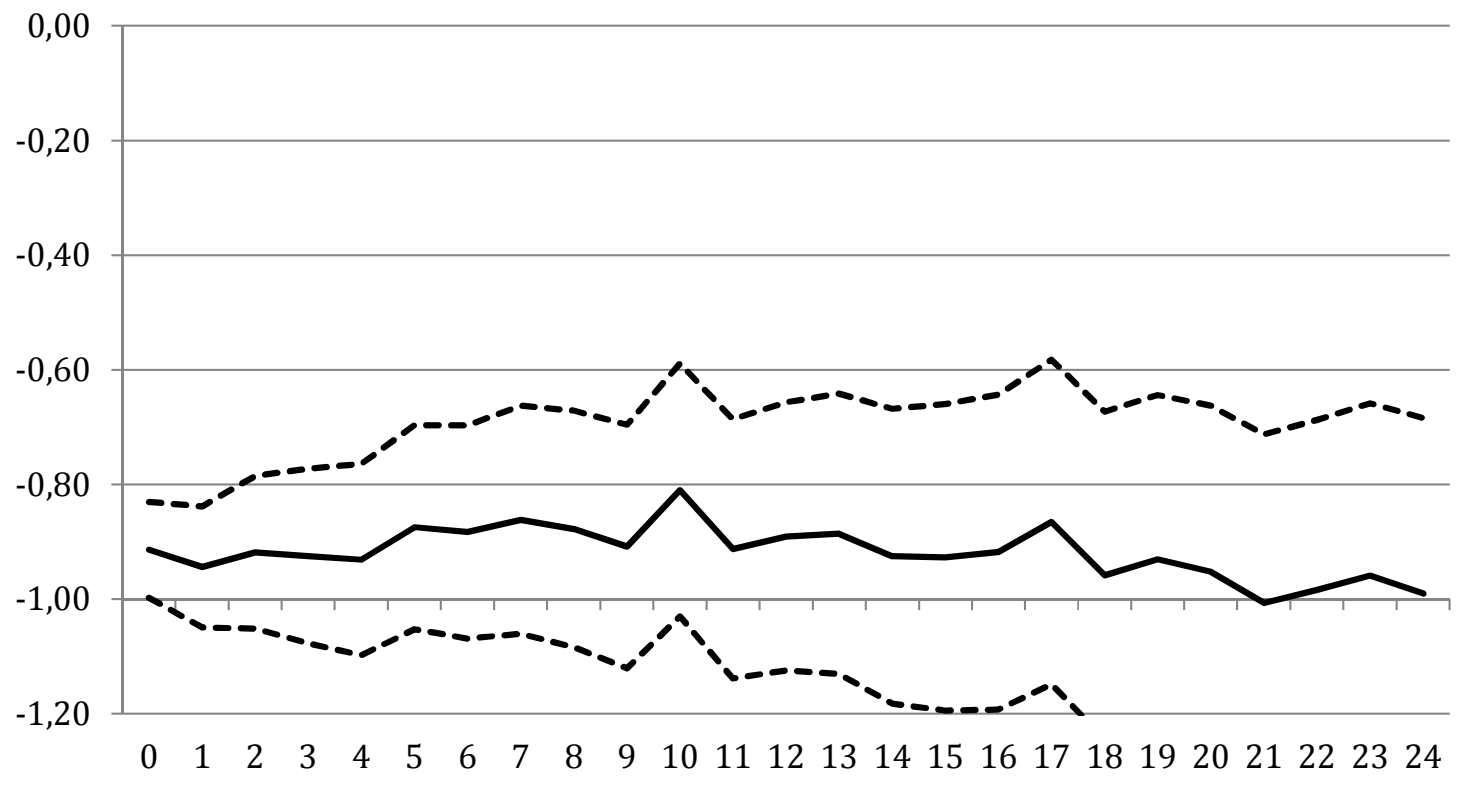

Figura 30: Pass-through de variações na taxa euro-dólar para o preço de exportações com invoice em USD - índice iUSDm2x25.

As figuras 31 e 32 repetem o exercício para os índices obtidos através das estratégias 1 e 3 , ambos com exclusão de $25 \%$ das caudas, e através da estratégias 2 , com exclusão de $15 \%$ e $5 \%$ das caudas.

Em todos os casos da figura 31, o pass-through acumulado $\beta_{R / D}$ associado a variações no câmbio real-dólar é próximo de zero no curto prazo, e cresce ao longo dos meses.

Para o índice iEURm1x25, os resultados são muito similares àquele obtido com o índice de referência. Após 24 meses, o pass-through acumulado atinge 38\%.

Para os índices iEURm2x15 e iEURm2x05, ambos obtidos com a estratégia 2, a estimativa pontual para o pass-through acumulado em 24 meses é de $42 \%$ e $51 \%$, respectivamente. A regressão que utiliza o índice iUSDm3x25 gera uma estimativa pontual do pass-through acumulado menor, de $20 \%$ após 24 meses. Nos três casos, o erro padrão dos coeficientes estimados aumenta consideravelmente em relação à estimativa com o índice de referência. 


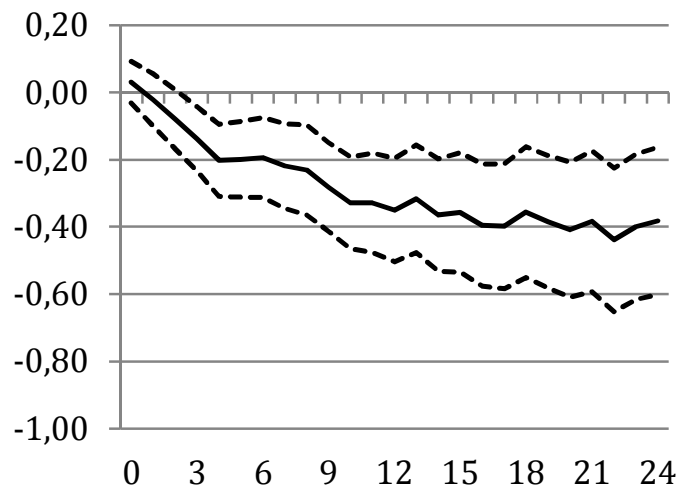

(a) iEURm1 125

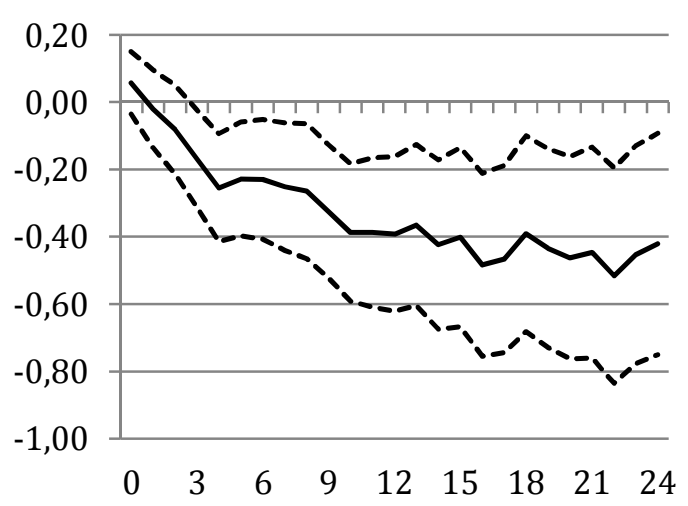

(c) iEURm2x15

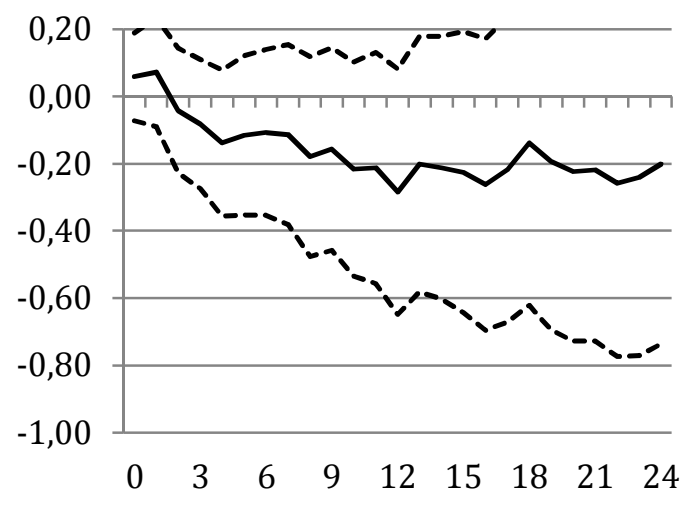

(b) iEURm $3 \times 25$

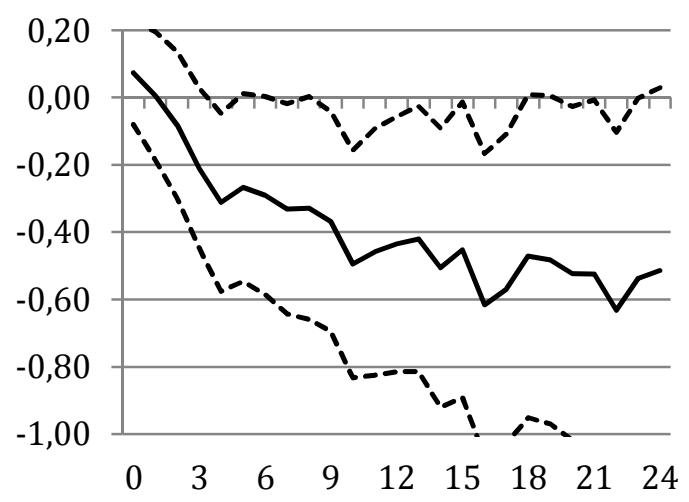

(d) iEURm2x05

Figura 31: Pass-through de variações na taxa dólar-real para o preço de exportações com invoice em USD. Índices utilizados são indicados abaixo de cada gráfico.

$\mathrm{Na}$ figura 32, a estimativa pontual do pass-through acumulado $\beta_{D / E}$, associado a variações no câmbio dólar-euro, mantém-se na faixa entre - 0,8 e -1 para todo o horizonte avaliado. Para o índice iEURm1x25, os resultados são muito similares àquele obtido com o índice de referência. Para os demais índices, o erro padrão dos coeficientes estimados aumenta consideravelmente. Mesmo para a estimativa com base no índice iEURm1x25, mais precisas, os coeficientes de pass-through não são diferentes de -1 ao nível de significância de $95 \%$ para todo o horizonte. 


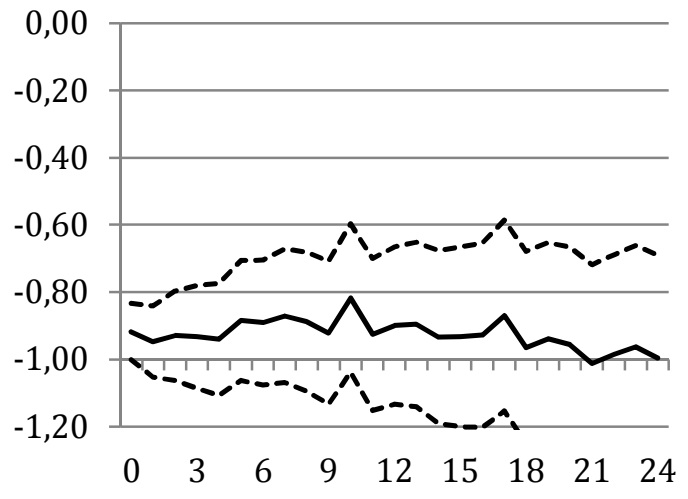

(a) iEURm1 125

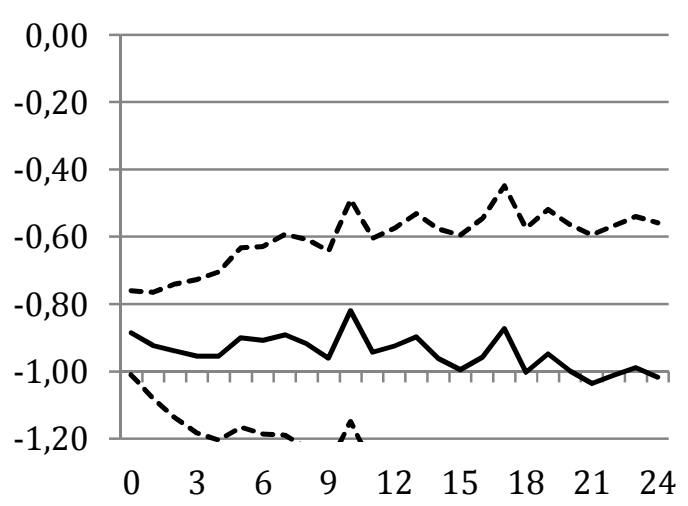

(c) iEURm2x15

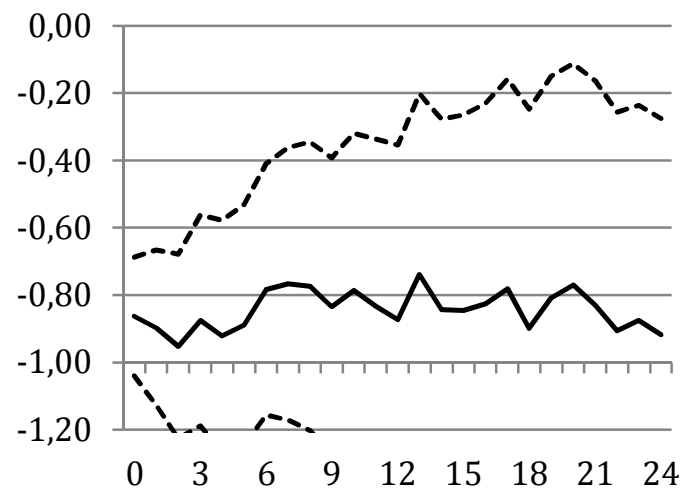

(b) iEURm3x25

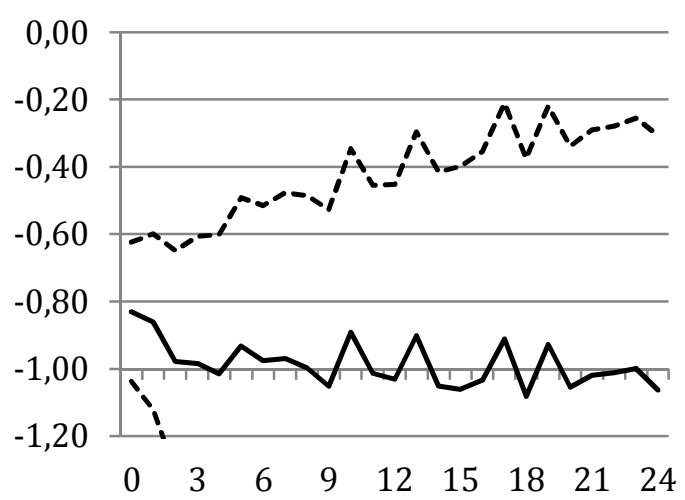

(d) iEURm2x05

Figura 32: Pass-through de variações na taxa euro-dólar para o preço de exportações com invoice em USD. Índices utilizados são indicados abaixo de cada gráfico.

Os resultados da estimação dos modelos dinâmicos são consistentes com a hipótese de que, no curto prazo, as exportações apresentam maior rigidez na moeda de invoice. No médio prazo, os preços respondem à variação de preços, mas o pass-through não é completo. Os resultados indicam que a maior parte do ajuste ocorre em resposta a variações na taxa de câmbio entre o real e a moeda de invoice da exportação. Para os índices de preço de exportações com invoice em USD, os resultados sugerem que variações entre o euro e o dólar são integralmente repassadas para os preços em euro, sem ajuste posterior.

É importante notar que os resultados são sensíveis à inclusão ou não da constante $\alpha$ nos modelos. Nas regressões acima, que incluem a constante, sua estimativa é consistentemente positiva, com valor em geral próximo a 0,004 e significativo. Os modelos capturam, portanto, uma tendência de crescimento de ambos os índices de preço de exportação, não relacionada à variação das taxas de câmbio no período. 
Para o índice de preços de exportações em EUR, a exclusão da constante tem efeito pequeno: o pass-through acumulado após 24 meses atinge 38\%, ante 35\% na regressão que inclui a constante - nos dois casos, com base no índice de referência iEURm2x25. Para o índice de preços de exportações com invoice em USD, a exclusão da constante resulta em pass-through mais elevado em resposta a variações na taxa real-dólar (-61\% após 24 meses, ante $-38 \%$ na regressão que não inclui a constante). O pass-through em resposta a variações na taxa dólar-euro tem estimativa pontual de $-68 \%$, ante $-99 \%$ na regressão sem a constante. Estes resultados ainda são consistentes com rigidez de curto prazo na moeda de invoice, mas sugerem que o preço de mercadorias exportadas em dólar respondem mais a variações no câmbio do que aquelas exportadas em euro. Por outro lado, para mercadorias exportadas em USD, a variação cambial dólar-euro é repassada integralmente no curto prazo para o preço em euro, mas tende a ser ajustada parcialmente ao longo do tempo.

\subsection{REGRESSÕES NO NÍVEL DA MERCADORIA}

A seção 5.1 buscou caracterizar a diferença de pass-through entre exportações com moedas de invoice diferentes a partir da construção de índices de preço agregados e posterior estimação de modelos dinâmicos, em linha com análise desenvolvida por Gopinath et al (2010). Esta seção segue estratégia diferente e estima o pass-through de câmbio com base na variação de preço observada diretamente para cada mercadoria.

A análise é baseada nas propostas Gopinath et al (2010) e de Fabling e Sanderson (2013), e se divide em uma estimativa do pass-through de curto prazo e outra de longo prazo. Os modelos utilizados nos dois artigos são muito similares, mas divergem na forma como efeitos fixos são utilizados nas regressões. Para a estimativa de curto prazo, as duas especificações levam a resultados semelhantes. Para o pass-through de longo prazo, os resultados mudam de forma significativa com a especificação.

Outra diferença importante entre os dois artigos é que Gopinath et al (2010), pela natureza dos dados que utilizam, são capazes de identificar o momento em que os preços das mercadorias mudam. Assim, conseguem estimar um pass-through condicional à mudança de preços da mercadoria, o que, em princípio, elimina a hipótese de rigidez estritamente nominal dos preços. 
Da mesma forma que na seção 5.1, a amostra utilizada para a estimação inclui exportações de bens diferenciados para países selecionados da União Europeia cuja moeda local seja o euro. A seção 5.2.1 apresenta os resultados do modelo de pass-through de curto prazo, e a seção 5.2.2 apresenta os resultados do modelo de pass-through de longo prazo.

\subsubsection{PASS-THROUGH DE CURTO PRAZO}

Para a estimativa do pass-through de curto prazo nas importações dos Estados Unidos, Gopinath et al (2010) selecionam inicialmente todos os meses nos quais uma mercadoria mudou de preço (dado na moeda de invoice). Em seguida estimam o pass-through com base nas variações de câmbio e de preço entre dois meses consecutivos desta amostra. O coeficiente estimado, portanto, é condicional a uma mudança de preços, de forma que a rigidez estritamente nominal não pode explicar o pass-through incompleto que os autores observam $^{32}$.

Fabling e Sanderson (2013) usam o artigo de Gopinath et al (2010) como referência, mas, como utilizam dados de natureza alfandegária e dependem do uso de valores unitários, não condicionam a estimativa de pass-through a uma mudança de preços. Alternativamente, Fabling e Sanderson (2013) estimam um pass-through de curto prazo como aquele observado entre duas exportações consecutivas da mesma mercadoria, independentemente da ocorrência ou não de uma mudança de preços (que não é observável diretamente, dada a utilização de valores unitários).

Esta dissertação também utiliza dados alfandegários e depende do uso do valor unitário como proxy do preço dos bens exportados. Segue, portanto, a mesma abordagem proposta por Fabling e Sanderson (2013), e estima o pass-through de curto prazo como aquele observado entre duas exportações consecutivas da mesma mercadoria. Seguindo os dois artigos de referência, esta seção define uma mercadoria como um trio NCM-Firma-País de Destino.

O modelo básico estimado é dado pela equação 5 abaixo, em que $M$ indexa a mercadoria.

\footnotetext{
${ }^{32}$ Os autores na realidade denominam este pass-through como de médio prazo, para diferenciá-lo do passthrough observado no período em que predomina a rigidez nominal de preços (i.e. antes da primeira mudança de preços pelas firmas).
} 


\section{Equação 5}

$$
\Delta P_{M, t}=\beta \cdot \Delta e_{t}+Z_{M, t}+\varepsilon_{M, t}
$$

Aqui, há outra diferença importante entre os artigos de Gopinath et al (2010) e de Fabling e Sanderson (2013). No primeiro artigo, todas as variações indicadas na equação são cumulativas entre as duas exportações. A variação de preços $\Delta P_{M, t}$ é dada pela diferença no logaritmo dos preços da mercadoria entre duas exportações consecutivas. A variação de câmbio $\Delta e_{t}$ é dada pela diferença no logaritmo da taxa de câmbio entre as duas exportações.

No artigo de Fabling e Sanderson (2013), as variações utilizadas são variações médias entre as duas exportações. A variação de preços $\Delta P_{M, t}$ é calculada como a diferença no logaritmo dos preços da mercadoria entre duas exportações consecutivas, normalizada pelo número de meses entre as exportações. A variação de câmbio $\Delta e_{t}$ é calculada como a diferença no logaritmo da taxa de câmbio entre as duas exportações, também normalizada pelo número de meses entre as exportações.

$Z_{M, t}$ contém variáveis de controle (variações na inflação, PIB), e inclui dummies de efeito fixo para grupos de produto definidos por segmentos do código SH e pelo país de destino. O uso de variações cumulativas no artigo de Gopinath et al (2010) e de variações médias no artigo de Fabling e Sanderson (2013) implica em funções diferentes para as dummies de efeito fixo, dado que o intervalo de tempo entre as exportações não é uniforme. Em Fabling e Sanderson (2013), as dummies capturam uma tendência comum aos preços de exportação de um grupo de produtos (i.e. capturam uma variação média por mês). Em Gopinath et al (2010), a variação de preços capturada pelas dummies não depende do número de meses entre as duas exportações (i.e. as dummies capturam uma variação média entre as exportações, sem controlar pelo período de tempo transcorrido entre elas).

A diferença entre as especificações não afeta de forma relevante as estimativas do passthrough de curto prazo, mas é significativa para as estimativas de longo prazo (seção 5.2.2). Tanto para a estimativa de curto, quanto de longo prazo, são apresentados os resultados das duas especificações. 
Na equação 5, seguindo Gopinath et al (2010), a variação de preços $\Delta P_{M, t}$ é calculada na moeda do importador ${ }^{33}$ (EUR). A variação de câmbio $\Delta e_{t}$ é dada em reais por unidade da moeda do importador. Assim, $\Delta e_{t}$ positivos indicam desvalorização do real. O coeficiente de interesse na equação é $\beta$, que corresponde ao pass-through de câmbio de curto prazo. Um coeficiente próximo de zero indica que o preço na moeda do importador não é afetado por variações do câmbio bilateral. Um coeficiente próximo de um (negativo) indica que o preço na moeda do importador é afetado integralmente por variações no câmbio bilateral, i.e. que o preço de exportação permanece constante em real.

Para testar a diferença no pass-through entre as moedas de invoice, o modelo da equação 5 é modificado inicialmente para a forma abaixo, em que $\delta_{L}$ é uma dummy que indica que a mercadoria foi exportada na moeda do importador (moeda local), e $\delta_{V}$ indica que a moeda de invoice é uma moeda veículo.

\section{Equação 6}

$$
\Delta P_{M, t}=\left(\beta_{L} \cdot \delta_{L}+\beta_{V} \cdot \delta_{V}\right) \cdot \Delta e_{t}+Z_{M, t}+\varepsilon_{M, t}
$$

A equação 6 foi estimada utilizando todas as exportações consecutivas da mesma mercadoria e que tenham sido realizadas na mesma moeda. Adicionalmente, foram adotados os seguintes critérios de inclusão e exclusão.

- O intervalo entre as duas exportações consecutivas não deve ser maior do que 5 meses, de forma a caracterizar o pass-through como de curto prazo, conforme proposta de Fabling e Sanderson (2013).

A sequência completa de exportações da mercadoria na moeda deve ser de no mínimo 18 meses, sem operações intermediárias em outras moedas. Em outras palavras, o intervalo entre a primeira e a última exportação da mercadoria na mesma moeda de invoice deve ser de pelo menos 18 meses.

- Foram excluídas pares de exportação em que pelo menos uma das transações tenha valor ou peso muito reduzido, ou valor unitário muito elevado (peso $<10 \mathrm{~kg}$, valor $<$ US\$10, valor unitário > US\$ 10 mil por kg).

${ }^{33}$ Nos artigos de referência e na literatura de pass-through, a moeda do importador é comumente denominada de moeda local. 
Foram excluídas variações extremas no valor unitário $(1 \%$ de cada cauda da distribuição).

Para as variáveis de controle, foram utilizadas somente dummies de efeito fixo para grupos de produto definidos pelos quatro primeiros dígitos do código NCM (equivalentes, em geral, aos quatro primeiros dígitos do $\mathrm{SH}$ ).

Foram estimados coeficientes segundo a especificação de Gopinath et al (2010), em que as variações são cumulativas entre as exportações, e segundo a especificação de Fabling e Sanderson (2013), que utilizam as variações cumulativas normalizadas pelo intervalo de tempo entre as operações.

As colunas 1 e 2 da tabela 24 abaixo indicam os resultados obtidos para a estimação da equação 6 para as especificações de Gopinath et al (2010) e de Fabling e Sanderson (2013), respectivamente. Os coeficientes estimados segundo as duas especificações indicam o mesmo comportamento dinâmico dos preços. O pass-through de curto prazo $\beta_{L}$ para exportações em moeda local (EUR) é próximo de zero, consistente com a hipótese de rigidez de preços na moeda de invoice, no curto prazo. Para exportações com invoice em USD (moeda veículo), o coeficiente $\beta_{V}$ é próximo de $20 \%$. Este resultado também é consistente com a rigidez de preços na moeda de invoice, dado que a correlação das taxas de câmbio BRL-USD e BRLEUR é próxima de $80 \%$ no período. 
Tabela 24: Coeficientes de pass-through de curto prazo para exportações com invoice em moeda local e moeda veículo.

\begin{tabular}{cccccc}
\hline \multicolumn{1}{c}{$(1)$} & $(2)$ & $(3)$ & $(4)$ & $(5)$ \\
\hline$\beta_{L}$ & $-0,050^{* *}$ & $-0,066^{* *}$ & $-0,048^{*}$ & $-0,065^{* *}$ & \\
& {$[0,0189]$} & {$[0,0220]$} & {$[0,0188]$} & {$[0,0219]$} & \\
\hline$\beta_{V}$ & $-0,221^{* * *}$ & $-0,225^{* * *}$ & & & $-0,150^{* * *}$ \\
& {$[0,0125]$} & {$[0,0164]$} & & & {$[0,0293]$} \\
\hline$\beta_{R / V}$ & & $-0,084^{* * *}$ & $-0,053^{* *}$ & \\
\hline \multirow{2}{*}{$\beta_{V / L}$} & & {$[0,0130]$} & {$[0,0173]$} & \\
\hline \multirow{2}{*}{$\mathrm{N}$} & 328.773 & 328.773 & 328.773 & 328.773 & 328.773 \\
\hline \multirow{2}{*}{$\mathrm{R}^{2}$} & 0,0010 & 0,0006 & $0,0050^{* * *}$ & $-0,982^{* * *}$ & \\
\hline
\end{tabular}

Seguindo Fabling e Sanderson (2013), o pass-through para exportações em moeda veículo (USD) é decomposto no pass-through entre o real e a moeda veículo $\left(\beta_{R / V}\right)$, e entre a moeda veículo e a moeda local $\left(\beta_{V / L}\right)$, conforme a equação 7 . Na equação, $\Delta e_{(R / V) t}$ e $\Delta e_{(V / L) t}$ representam, respectivamente, a variação no câmbio real-dólar, e no câmbio dólareuro.

\section{Equação 7}

$$
\Delta P_{M, t}=\beta_{L} \cdot \delta_{L} \cdot \Delta e_{t}+\delta_{V} \cdot\left(\beta_{R / V} \cdot \Delta e_{(R / V) t}+\beta_{V / L} \cdot \Delta e_{(V / L) t}\right)+Z_{M, t}+\varepsilon_{M, t}
$$

As colunas 3 e 4 da tabela 24 indicam os resultados obtidos para a estimação da equação 7 para a especificação de Gopinath et al (2010) e de Fabling e Sanderson (2013), respectivamente. Os coeficientes estimados segundo as duas especificações indicam o mesmo comportamento dinâmico dos preços. O pass-through de curto prazo $\beta_{L}$ para exportações em EUR é próximo de zero, mesmo resultado obtido para a estimação da equação 6 . Nas exportações em USD, o pass-through $\beta_{R / V}$ para variações entre o real e o dólar é próximo de zero, e o coeficiente de pass-through $\beta_{V / L}$ para variações entre o dólar e o euro é próximo de um (negativo), consistente com a hipótese de rigidez dos preços na moeda de invoice, no curto prazo. 
A coluna 5 tabela 24 indica os resultados obtidos para a regressão dada pela equação 8, que permite que o pass-through seja definido de forma específica para cada capítulo da NCM ( 2 primeiros dígitos), e um coeficiente geral capture o efeito da moeda de invoice ser uma moeda veículo. O coeficiente $\beta_{V}$ é consistente com o obtido nas duas estimações anteriores e sugere que a diferença de pass-through entre exportações com moeda de invoice diferente não se deve apenas ao seu padrão de uso entre grandes setores.

\section{Equação 8}

$$
\Delta P_{M, t}=\alpha+\left(\sum \beta_{M, L} \cdot Z_{M}\right) \cdot \Delta e_{t}+\beta_{V} \cdot \delta_{V} \cdot \Delta e_{t}+Z_{M}+\varepsilon_{M, t}
$$

Os resultados das regressões acima confirmam o observado na seção 5.1. No curto prazo, os preços médios comportam-se de acordo com a hipótese de rigidez na moeda de invoice.

Ao contrário das regressões nos dois artigos de referência, os resultados da tabela 24 não incluem controles para a inflação de custos de produção no Brasil, ou para a atividade econômica nos países de destino. A inclusão de um controle para os custos no Brasil foi testada, sem alteração relevante nas estimativas dos coeficientes de pass-through. Como proxy da variação dos custos de produção, utilizou-se o Índice de Preços por Atacado-Mercado (IPA-M), produzido pela Fundação Getúlio Vargas.

\subsubsection{PASS-TROUGH DE LONGO PRAZO}

Para a estimativa do pass-through de longo prazo, a especificação de Fabling e Sanderson (2013) segue a especificação de Gopinath et al (2010), mas, como no caso das estimativas de curto prazo, é diferente na função das dummies de efeito fixo, e na impossibilidade de condicionar a regressão a um evento de mudança de preço da mercadoria.

Gopinath et al (2010) estimam o pass-through de longo prazo nas importações americanas com base nas variações entre o primeiro e último mês em que ocorre uma mudança de preço da mercadoria importada. Como não conseguem observar diretamente as mudanças de preço, Fabling e Sanderson (2013) estimam o pass-through de longo prazo com base simplesmente na primeira e última observações de cada mercadoria na amostra. 
Esta seção segue inicialmente a estratégia de Fabling e Sanderson (2013) e estima o pass-through de longo prazo entre a primeira e a última exportações de cada mercadoria, realizadas na mesma moeda de invoice - e sem o uso de outras moedas de invoice nas exportações intermediárias. Em seguida algumas formas alternativas de seleção do par de transações são utilizadas, de forma a observar em mais detalhe a resposta de longo prazo dos preços de exportação.

Como na seção anterior, uma mercadoria é definida como um trio NCM-Firma-País de Destino. Os modelos utilizados para as estimações seguem as equações 6 , 7, e 8 da estimativa de curto prazo. São apresentados os resultados tanto para o uso de variações acumuladas entre as exportações - seguindo Gopinath et al (2010), quanto para o uso de variações médias entre as exportações - seguindo Fabling e Sanderson (2013).

Parte das mercadorias são excluídas da seleção, com base em critérios similares aos aplicados para a estimativa de pass-through de curto prazo.

- O intervalo mínimo entre a primeira e a última exportações da mercadoria na moeda de invoice é 18 meses, sem operações intermediárias em outras moedas.

- Foram excluídas pares de exportação em que pelo menos uma das transações tenha valor ou peso muito reduzido, ou valor unitário muito elevado (peso $<10 \mathrm{~kg}$, valor $<$ US\$10, valor unitário > US\$ 10 mil por kg).

- Foram excluídas variações extremas no valor unitário (1\% de cada cauda da distribuição).

As colunas 1 e 2 da tabela 25 abaixo indicam os resultados obtidos para a estimação da equação 6 para as especificações de Gopinath et al (2010) - com variações cumulativas, e de Fabling e Sanderson (2013) - com variações médias, respectivamente. Conforme o esperado, os coeficientes de longo prazo indicam pass-through mais elevado tanto para exportações em moeda local (EUR) quanto para exportações em moeda veículo (USD). Nesta especificação, o pass-through nas exportações em moeda local é significativamente menor do que nas exportações em moeda veículo - cerca de $30 \%$ para exportações em moeda local, ante cerca de $50 \%$ para exportações em moeda veículo. O resultado sugere que, mesmo no longo prazo, exportações em moeda local tendem a apresentar pass-through menor, i.e. os preços na moeda do importador variam menos com a taxa bilateral de câmbio. 
As colunas 3 e 4 da tabela 25 indicam os resultados obtidos para a estimação da equação 7 para as especificações de Gopinath et al (2010) e de Fabling e Sanderson (2013), respectivamente. Neste caso, é possível observar diferenças relevantes entre os coeficientes estimados com as duas especificações. Na especificação de Gopinath et al (2010), o passthrough $\beta_{R / V}$ e $\beta_{V / L}$, para exportações com invoice em USD, são estimados em $52 \%$ e $61 \%$, respectivamente, o que indica que, no longo prazo, os preços em EUR se ajustam parcialmente às variações no câmbio BRL-USD e USD-EUR. Na especificação, de Fabling e Sanderson (2013), os coeficientes $\beta_{R / V}$ e $\beta_{V / L}$ são estimados em $37 \%$ e $94 \%$, respectivamente, o que indica que os preços em EUR respondem quase integralmente a variações no câmbio USD-EUR, sem ajustes no longo prazo, i.e. toda variação no câmbio USD-EUR é repassada aos preços do importador, mesmo no longo prazo.

A coluna 5 tabela 25 indica os resultados obtidos para a regressão dada pela equação 8 . O coeficiente $\beta_{V}$ de pass-through para exportações com invoice em USD é consistente com os resultados obtidos nas duas estimações anteriores e sugere que a diferença de pass-through entre exportações com invoice em EUR e USD não se deve apenas ao seu padrão de uso entre setores.

Tabela 25: Coeficientes de pass-through de longo prazo para exportações com invoice em moeda local e moeda veículo.

\begin{tabular}{cccccc}
\hline \multicolumn{1}{c}{$(1)$} & $(2)$ & $(3)$ & $(4)$ & $(5)$ \\
\hline$\beta_{L}$ & $-0,311^{* * *}$ & $-0,341^{* * *}$ & $-0,298^{* * *}$ & $-0,296^{* * *}$ & \\
& {$[0,0291]$} & {$[0,0287]$} & {$[0,0294]$} & {$[0,0288]$} & \\
\hline \multirow{2}{*}{$\beta_{V}$} & $-0,545^{* * *}$ & $-0,505^{* * *}$ & & & $-0,170^{* * *}$ \\
& {$[0,0161]$} & {$[0,0155]$} & & & {$[0,0337]$} \\
\hline \multirow{2}{*}{$\beta_{R / V}$} & & $-0,522^{* * *}$ & $-0,368^{* * *}$ & \\
& & & {$[0,0180]$} & {$[0,0184]$} & \\
$\beta_{V / L}$ & & $-0,613^{* * *}$ & $-0,938^{* * *}$ & \\
& & & {$[0,0283]$} & {$[0,0351]$} & \\
\hline \multirow{2}{*}{$\mathrm{N}$} & 23.967 & 23.967 & 23.967 & 23.967 & 23.967 \\
\hline \multirow{2}{*}{$\mathrm{R}^{2}$} & 0,0515 & 0,0493 & 0,0505 & 0,0569 & 0,0552 \\
\hline
\end{tabular}


Ao contrário das estimativas de curto prazo, os resultados acima são sensíveis à inclusão de um controle para os preços no Brasil. A tabela 26 repete as regressões anteriores, com a inclusão do IPA-M entre as variáveis de controle. O primeiro ponto notável é que o coeficiente do IPA-M é estimado com valores negativos nas especificações 2 e 5 , sugerindo que variações positivas do IPA-M estão associadas a variações negativas nos preços de exportação. O coeficiente só tem o sinal esperado nas especificações 1 e 3, que seguem Gopinath et al (2010).

Os coeficientes de pass-through têm diferenças significativas em relação aos estimados sem o controle pelo IPA-M, mas ainda sugerem que, quando expressos em euro, o preço das mercadorias com invoice em EUR responde menos a variações no câmbio bilateral do que o preço de mercadorias com invoice em USD.

Tabela 26: Coeficientes de pass-through de longo prazo para exportações com invoice em moeda local e moeda veículo - regressões com controle pelo IPA-M.

\begin{tabular}{|c|c|c|c|c|c|}
\hline & (1) & (2) & (3) & (4) & (5) \\
\hline$\beta_{L}$ & $\begin{array}{c}-0,403^{* * *} \\
{[0,0300]}\end{array}$ & $\begin{array}{c}-0,195^{* * *} \\
{[0,0378]}\end{array}$ & $\begin{array}{c}-0,407^{* * *} \\
{[0,0299]}\end{array}$ & $\begin{array}{c}-0,286^{* * *} \\
{[0,0384]}\end{array}$ & \\
\hline$\beta_{V}$ & $\begin{array}{c}-0,643^{* * *} \\
{[0,0180]}\end{array}$ & $\begin{array}{c}-0,363^{* * *} \\
{[0,0285]}\end{array}$ & & & $\begin{array}{c}-0,174^{* * *} \\
{[0,0337]}\end{array}$ \\
\hline$\beta_{R / V}$ & & & $\begin{array}{c}-0,594^{* * *} \\
{[0,0184]}\end{array}$ & $\begin{array}{c}-0,360^{* * *} \\
{[0,0284]}\end{array}$ & \\
\hline$\beta_{V / L}$ & & & $\begin{array}{c}-1,061^{* * *} \\
{[0,0386]}\end{array}$ & $\begin{array}{c}-0,923^{* * *} \\
{[0,0533]}\end{array}$ & \\
\hline$\gamma_{I P A}$ & $\begin{array}{l}0,264^{* * *} \\
{[0,0221]}\end{array}$ & $\begin{array}{c}-0,375^{* * *} \\
{[0,0632]}\end{array}$ & $\begin{array}{l}0,456^{* * *} \\
{[0,0271]}\end{array}$ & $\begin{array}{c}-0,027 \\
{[0,0689]}\end{array}$ & $\begin{array}{c}-0,344^{* * *} \\
{[0,0627]}\end{array}$ \\
\hline $\mathrm{N}$ & 23.967 & 23.967 & 23.967 & 23.967 & 23.967 \\
\hline $\mathrm{R}^{2}$ & 0,0572 & 0,0507 & 0,0632 & 0,0569 & 0,0564 \\
\hline
\end{tabular}

A amostra utilizada para as regressões das tabelas 25 e 26 contém variações de preço entre exportações com intervalo entre 18 e 131 meses, com intervalo mediano de 47 meses. Nas regressões abaixo, são selecionados pares de exportação com intervalos de tempo mais 
restritos. Os pares são selecionados entre exportações de uma mesma mercadoria, na mesma moeda de invoice, e sem exportações intermediárias em outras moedas.

A tabela 27 apresenta a estimação do pass-through para exportações na mesma moeda de invoice com intervalo entre 18 e 23 meses. A tabela 28 apresenta os resultados para exportações com intervalo entre 24 e 35 meses, e a tabela 29, para intervalos entre 36 e 47 meses. As especificações em cada coluna seguem a mesma ordem utilizada nas tabelas anteriores. Como há menos variação nos intervalos de tempo, há menos diferença entre as especificações de Gopinath et al (2010) e de Fabling e Sanderson (2013).

Para as exportações em EUR, as estimativas nas tabelas 27 a 29 indicam que o passthrough mantém-se próximo a 25\%, para intervalos de 18 a 47 meses. Para as exportações em USD, o pass-through estimado para um intervalo de 18 a 23 meses é próximo de 39\%, e atinge 55\% na estimativa para o intervalo de 36 a 47 meses. Essas estimativas indicam uma diferença significativa no pass-through de mercadorias exportadas em EUR e USD, variando de $15 \%$ na tabela 27 , a cerca de $30 \%$, nas tabelas 28 e 29 . A diferença sugere que, do ponto de vista do importador, o preço das exportações que usam o EUR (moeda local) responde menos a variações na taxa de câmbio, quando comparadas às exportações em USD (moeda veículo), mesmo no longo prazo.

Para as exportações em USD, as regressões contra a variação BRL-EUR decomposta nas variações BRL-USD e USD-EUR indicam que, no longo prazo, as variações da taxa realdólar são repassadas parcialmente para os preços em euro (28\% nas estimativa com intervalos de 18 a 23 meses, e entre $43 \%$ e $44 \%$ nas estimativas com intervalos de 36 a 47 meses). Variações da taxa USD-EUR, que são repassadas quase integralmente para os preços em EUR no curto prazo, mantêm pass-through elevado na estimativa para exportações com intervalos de 36 a 47 meses, embora um pouco menor do que as estimativas para intervalos de 18 a 23 meses $-88 \%$, ante $96 \%$, respectivamente.

De forma geral, os resultados são consistentes com a hipótese de que as diferenças de pass-through entre exportações com moedas de invoice diferente não são apenas função da rigidez nominal de preços na moeda de invoice. Mesmo no longo prazo, nas especificações utilizadas nesta seção, é possível observar diferenças significativas entre os coeficientes de pass-through entre as exportações em dólar e em euro. Mercadorias que utilizam o euro como 
moeda de invoice na exportação apresentam pass-through menor, i.e. seus preços na moeda do importador variam menos em resposta a variações no câmbio bilateral euro-real.

Tabela 27: Coeficientes de pass-through de longo prazo para exportações com invoice em moeda local e moeda veículo, com intervalo de 18 a 23 meses.

\begin{tabular}{|c|c|c|c|c|c|}
\hline & (1) & (2) & (3) & (4) & (5) \\
\hline$\beta_{L}$ & $\begin{array}{c}-0,236^{* * *} \\
{[0,0153]}\end{array}$ & $\begin{array}{c}-0,235^{* * *} \\
{[0,0154]}\end{array}$ & $\begin{array}{c}-0,241^{* * *} \\
{[0,0152]}\end{array}$ & $\begin{array}{c}-0,240^{* * *} \\
{[0,0153]}\end{array}$ & \\
\hline$\beta_{V}$ & $\begin{array}{c}-0,389^{* * *} \\
{[0,0091]}\end{array}$ & $\begin{array}{c}-0,388^{* * *} \\
{[0,0093]}\end{array}$ & & & $\begin{array}{c}-0,144^{* * *} \\
{[0,0181]}\end{array}$ \\
\hline$\beta_{R / V}$ & & & $\begin{array}{c}-0,281^{* * *} \\
{[0,0103]}\end{array}$ & $\begin{array}{c}-0,283^{* * *} \\
{[0,0104]}\end{array}$ & \\
\hline$\beta_{V / L}$ & & & $\begin{array}{c}-0,960 * * * \\
{[0,0276]}\end{array}$ & $\begin{array}{c}-0,956^{* * *} \\
{[0,0280]}\end{array}$ & \\
\hline $\mathrm{N}$ & 41.562 & 41.562 & 41.562 & 41.562 & 41.562 \\
\hline $\mathrm{R}^{2}$ & 0,0470 & 0,0458 & 0,0581 & 0,0564 & 0,0529 \\
\hline
\end{tabular}


Tabela 28: Coeficientes de pass-through de longo prazo para exportações com invoice em moeda local e moeda veículo, com intervalo de 24 a 35 meses.

\begin{tabular}{|c|c|c|c|c|c|}
\hline & (1) & (2) & (3) & (4) & (5) \\
\hline$\beta_{L}$ & $\begin{array}{c}-0,234^{* * *} \\
{[0,0111]}\end{array}$ & $\begin{array}{c}-0,228^{* * *} \\
{[0,0112]}\end{array}$ & $\begin{array}{c}-0,230^{* * *} \\
{[0,0111]}\end{array}$ & $\begin{array}{c}-0,224^{* * *} \\
{[0,0111]}\end{array}$ & \\
\hline$\beta_{V}$ & $\begin{array}{c}-0,533^{* * *} \\
{[0,0069]}\end{array}$ & $\begin{array}{c}-0,519^{* * *} \\
{[0,0069]}\end{array}$ & & & $\begin{array}{c}-0,311^{* * *} \\
{[0,0135]}\end{array}$ \\
\hline$\beta_{R / V}$ & & & $\begin{array}{c}-0,409 * * * \\
{[0,0091]}\end{array}$ & $\begin{array}{c}-0,385^{* * *} \\
{[0,0090]}\end{array}$ & \\
\hline$\beta_{V / L}$ & & & $\begin{array}{c}-0,883^{* * *} \\
{[0,0184]}\end{array}$ & $\begin{array}{c}-0,916^{* * *} \\
{[0,0188]}\end{array}$ & \\
\hline $\mathrm{N}$ & 68.371 & 68.371 & 68.371 & 68.371 & 68.371 \\
\hline $\mathrm{R}^{2}$ & 0,0872 & 0,0833 & 0,0928 & 0,0902 & 0,0920 \\
\hline
\end{tabular}

Tabela 29: Coeficientes de pass-through de longo prazo para exportações com invoice em moeda local e moeda veículo, com intervalo de 36 a 47 meses.

\begin{tabular}{|c|c|c|c|c|c|}
\hline & (1) & (2) & (3) & (4) & (5) \\
\hline$\beta_{L}$ & $\begin{array}{c}-0,266^{* * *} \\
{[0,0142]}\end{array}$ & $\begin{array}{c}-0,260^{* * *} \\
{[0,0141]}\end{array}$ & $\begin{array}{c}-0,249 * * * \\
{[0,0142]}\end{array}$ & $\begin{array}{c}-0,244^{* * *} \\
{[0,0141]}\end{array}$ & \\
\hline$\beta_{V}$ & $\begin{array}{c}-0,555^{* * *} \\
{[0,0083]}\end{array}$ & $\begin{array}{c}-0,553^{* * *} \\
{[0,0083]}\end{array}$ & & & $\begin{array}{c}-0,303^{* * *} \\
{[0,0169]}\end{array}$ \\
\hline$\beta_{R / V}$ & & & $\begin{array}{c}-0,438^{* * *} \\
{[0,0110]}\end{array}$ & $\begin{array}{c}-0,433^{* * *} \\
{[0,0111]}\end{array}$ & \\
\hline$\beta_{V / L}$ & & & $\begin{array}{c}-0,882^{* * *} \\
{[0,0216]}\end{array}$ & $\begin{array}{c}-0,884^{* * *} \\
{[0,0219]}\end{array}$ & \\
\hline $\mathrm{N}$ & 45.565 & 45.565 & 45.565 & 45.565 & 45.565 \\
\hline $\mathrm{R}^{2}$ & 0.096126 & 0.096063 & 0.10153 & 0.10141 & 0.11176 \\
\hline
\end{tabular}




\section{CONCLUSÃO}

A partir de microdados do Siscomex Exportação mantidos pelo Banco Central do Brasil, a dissertação buscou caracterizar a heterogeneidade no uso de moedas de invoice nas exportações brasileiras.

De forma geral, o dólar americano é predominante como moeda de invoice, independentemente do corte realizado na amostra. Para a exportação de bens diferenciados, no entanto, é possível observar maior heterogeneidade, em especial nas exportações para a União Europeia. Por outro lado, o uso do real nas exportações é limitado a operações de baixo valor, e cujo destino seja países do Mercosul ou a Bolívia.

O uso do euro e do dólar como moeda de invoice nas exportações de bens diferenciadas para a União Europeia foi analisado em mais detalhes. Não foram observados, no entanto, padrões evidentes entre o uso de cada uma das moedas e características da firma. A abertura por CNAE e por capítulo da NCM indica que o uso das moedas varia entre setores, mas a identificação setorial não esgota a variação na escolha da moeda de invoice, e a maior parte dos setores ainda exibem participação do euro entre $20 \%$ e $60 \%$.

Após a caracterização do uso da moeda de invoice nas exportações brasileiras, a dissertação segue a proposta de dois artigos recentes para analisar a resposta dinâmica dos preços de exportação a variações do câmbio, tomando a moeda de invoice como dada. Os resultados obtidos são consistentes com aqueles obtidos nos artigos de referência. No curto prazo, os preços de exportação apresentam maior rigidez na moeda de invoice em que são negociados. No longo prazo, o pass-through de câmbio é maior para as duas moedas de invoice, mas ainda é possível observar diferenças entre os coeficientes para exportações em moeda local (o euro) e em moeda veículo (o dólar): mesmo no longo prazo, e do ponto de vista do importador, o preço de exportações com invoice na moeda local (a moeda do importador) respondem menos a variações no câmbio bilateral.

Os resultados obtidos na dissertação apontam para algumas extensões possíveis na investigação sobre a escolha das moedas de invoice nas exportações brasileiras, e sua relação com a dinâmica de preços de exportação. Em primeiro lugar, enquanto na seção 3 a participação relativa do euro e do dólar como moedas de invoice é apresentada segundo várias características da firma, seria interessante formalizar a análise em um modelo de regressão 
logística ou probit, em especial para avaliar a influência das diversas dimensões quando testadas simultaneamente em um modelo de escolha de moeda de invoice.

Em segundo lugar, seria interessante caracterizar com mais detalhes o uso do real no comércio com países do Mercosul e Bolívia, em especial pelo contraste entre o volume elevado em quantidade de operações e seu valor reduzido.

Em terceiro lugar, ainda que os registros do Siscomex não tragam explicitamente a informação de que a transação foi realizada entre empresas do mesmo grupo, talvez seja possível construir uma proxy para esse tipo de transação com base na comparação dos nomes do exportador e do importador. Com base na proxy, a diferença entre transações de mercado e transações intrafirma poderia ser observada tanto na escolha da moeda de invoice, quanto na dinâmica dos preços de exportação.

Por último, enquanto as variações de preço no curto e médio prazos seguem de forma mais evidente as variações nas taxas de câmbio, os resultados obtidos para as variações no longo prazo são mais sensíveis à especificação dos modelos de regressão, inclusive à inclusão de controles para a variação de custo do produto exportado. Assim, é importante avaliar a adequação de outros modelos econométricos para a estimação do pass-through de longo prazo, além de avaliar a sensibilidade dos resultados ao controle de outras características da firma ou da transação - por exemplo, controlando transações intrafirma. 


\section{BIBLIOGRAFIA}

Alterman (1991); "Price Trends in U.S. Trade - New Data, New Insights"; em "International Economic Transactions: Issues in Measurement and Empirical Research", capítulo 4, pp. 109143, NBER Books; Jun 1991.

Araújo, Kannebley, Esteves e Silva (2010); "Padrões Microeconômicos de Comércio Internacional e a Estratégia Brasileira de Exportação"; IPEA, Texto para Discussão n. 1473; Fev 2010.

Banco Central do Brasil (2014); "Censo de Capitais Estrangeiros no País - Resultados para 2012"; Acessado em Jun 2014; http://www.bcb.gov.br/Rex/CensoCE/port/Censo 2013 anobase 2012 - resultados.pdf.

Berman, Martin, e Mayer (2012); "How do Different Exporters React to Exchange Rate Changes?"; The Quarterly Journal of Economics, v. 127, n. 1, pp. 437-492; Jan 2012.

Chatterjee, Dix-Carneiro e Vichyanond (2011); "Multi-Product Firms and Exchange Rate Fluctuations" ; American Economic Journal: Economic Policy, v. 5, n. 2, pp. 77-110; Mai 2013.

Chen e Rogoff (2003); "Commodity currencies"; Journal of International Economics, v. 60, n.1, pp. 133-160; Mai 2003.

Devereux, Dong e Tomlin (2013); "Exchange Rate Pass-Through, Currency Invoicing and Trade Partners"; Versão preliminar, 24 de maio de 2013; http://www.dallasfed.org/assets/documents/institute/events/2013/paper_tomlin.pdf, acessado em Abr 2014.

Eaton, Kortum e Kramarz (2004); "DissectingTrade: F irms, Industries, and Export Destinations"; The American Economic Review, v. 94, n. 2, pp. 150-154; Mai 2004.

Engels (2006); "Equivalence Results for Optimal Pass-Through, Optimal Indexing to Exchange Rates, and Optimal Choice of Currency For Export Pricing"; Journal of the European Economic Association, v. 4, n. 6, pp. 1249-1260; Dez 2006. 
Fabling e Sanderson (2013); "Export performance, invoice currency, and heterogeneous exchange rate pass-through"; Discussion Paper Series, Reserve Bank of New Zealand; Fev 2013.

Feenstra (1989); "Symmetric pass-through of tariffs and exchange rates under imperfect competition: An empirical test"; Journal of International Economics, v. 27, n. 1-2, pp. 25-45; Ago 1989.

Fitzgerald e Haller (2014); "Pricing-to-Market: Evidence From Plant-Level Prices"; Review of Economic Studies, v. 81, n. 2, pp. 761-786; Abr 2014.

Friberg e Wilander (2007); "Price Setting Transactions and the Role of Denominating Currency in FX Markets"; Sveriges Riksbank Working Paper Series; Jan 2007.

Goldberg e Campa (2002); "Exchange Rate Pass-Through into Import Prices: A Macro or Micro Phenomenon?"; NBER Working Paper, n. 8934; Mai 2002.

Goldberg e Knetter (1997); “Goods Prices and Exchange Rates: What Have We Learned?”; Journal of Economic Literature, v. 35, n. 3, pp. 1243-1272; Set 1997.

Goldberg e Tille (2005) "Networks versus markets in international trade"; Journal of International Economics.

Goldberg e Tille (2009); "Micro, Macro, and Strategic Forces in International Trade Invoicing"; NBER Working Paper, n. 15470; Nov 2009.

Gomes e Ellery (2007); "Perfil da Exportações, Produtividade e Tamanho das Firmas no Brasil”; Revista Brasileira de Economia, v. 61, n. 1, pp. 33-48; Jan-Mar 2007.

Gopinath e Rigobon (2008); “Sticky Borders”; The Quarterly Journal of Economics, v. 123, n. 2, pp. 531-575; Mai 2008.

Gopinath, Itskhoki e Rigobon (2010); "Currency Choice and Exchange Rate PassThrough.”; The American Economic Review, v. 100, n. 1, pp. 304-336; Mar 2010.

Guimarães, Falcão, Pourchet, Pinheiro, Markwald (1997); “Índices de preço e quantum das exportações brasileiras"; FUNCEX, Texto para Discussão n. 121; Jul 1997. 
Haveman (2014); "International Trade Data"; Acessado em Fev 2014; http://www.macalester.edu/research/economics/page/haveman/Trade.Resources/TradeData.ht $\underline{\mathrm{ml}}$.

Kamps (2006); "The Euro as Invoicing Currency in International Trade"; European Central Bank, Working Paper Series, n. 665; Ago 2006.

Knetter (1989) "Price Discrimination by U.S. and German Exporters"; The American Economic Review, v. 79, n. 1, pp. 198-210; Mar 1989.

Krugman (1986); "Pricing-to-market when the exchange rate changes"; NBER Working Paper, n. 1926; Mai 1986.

MDIC (2014a) Metodologia de produção de estatísticas de comércio exterior, "Fator agregado: conceito"; $\quad$ Acessado em $\quad$ Fev 2014; www.desenvolvimento.gov.br/arquivos/dwnl_1338918538.doc.

MDIC (2014b) Metodologia de produção de estatísticas de comércio exterior, "Tabelas (zip)"; Acessado em $\quad$ Fev 2014; www.desenvolvimento.gov.br//arquivos/dwnl_1392202618.zip.

Menon (1992); "Exchange rates and prices of Australian manufactured exports"; Weltwirtschaftliches Archiv, v. 128, n. 4, pp 695-710; 1992.

Menon (2005); "Exchange Rate Pass-Through"; Journal of Economic Surveys, v. 9, n. 2, pp. 197-231; Jun 2005.

Rauch (1999) "Networks versus markets in international trade"; Journal of International Economics, vol. 48, n. 1, pp. 7-35; Jun 1999.

Rogoff (1996); "The Purchasing Power Parity Puzzle"; Journal of Economic Literature, v. 34, n. 2, pp. 647-668; Jun 1996.

UNStats (2014) Complete HS and SITC conversion and correspondence tables along with detailed note on its conversion methodology; Acessado em Fev 2014; http://unstats.un.org/unsd/trade/conversions/HS\%20Correlation\%20and\%20Conversion\%20ta bles.htm. 
Whitman (1975); "Global Monetarism and the Monetary Approach to the Balance of Payments"; Brookings Papers on Economic Activity, n. 3; 1975. 


\section{ANEXO A CÓDIGOS DE ENQUADRAMENTO}

A terceira coluna da tabela abaixo indica se o código de enquadramento foi incluído ou não no estudo. Para comparação, a coluna 4 indica o critério adotado pelo MDIC na compilação da balança comercial. A coluna 5 indica a ocorrência de cada código em amostra preliminar de registros para o período 1995-2012.

Tabela 30: Enquadramentos incluídos no estudo.

\begin{tabular}{|c|c|c|c|c|}
\hline Enquadramento & Descrição & $\begin{array}{c}\text { Critério } \\
\text { adotado no } \\
\text { estudo }\end{array}$ & $\begin{array}{c}\text { Critério } \\
\text { adotado na } \\
\text { balança } \\
\text { comercial }\end{array}$ & $\begin{array}{c}\text { Ocorrências (\% } \\
\text { do total) }\end{array}$ \\
\hline 80000 & Exportação normal & Incluído & Incluído & $57,3 \%$ \\
\hline 80001 & Registro simplificado & Incluído & Incluído & $0,1 \%$ \\
\hline 80103 & Exportação sujeita a laudo de análise sem retenção & Incluído & Incluído & $\begin{array}{c}\text { Sem ocorrências } \\
\text { na amostra }\end{array}$ \\
\hline 80104 & Exportação com margem não sacada & Incluído & Incluído & $0,0 \%$ \\
\hline 80108 & BEFIEX & Incluído & Incluído & $1,2 \%$ \\
\hline 80109 & Exportação em moeda convênio & Incluído & Incluído & $0,0 \%$ \\
\hline 80113 & $\begin{array}{l}\text { Exportação de carne bovina "in natura" (Cota } \\
\text { Hilton), para a União Europeia }\end{array}$ & Incluído & Incluído & $0,0 \%$ \\
\hline 80116 & $\begin{array}{l}\text { Exportação ao amparo do Sistema Geral de } \\
\text { Preferência (SGP) }\end{array}$ & Incluído & Incluído & $8,6 \%$ \\
\hline 80119 & $\begin{array}{l}\text { Regime automotivo (Portaria MIC/MF 1, de } \\
\text { 05/01/96, e Decreto 1.761, de 26/12/95) }\end{array}$ & Incluído & Incluído & $3,7 \%$ \\
\hline 80170 & $\begin{array}{l}\text { Exportação definitiva de bens que saíram do país } \\
\text { temporariamente }\end{array}$ & Incluído & Incluído & $0,0 \%$ \\
\hline 80180 & Exportação de produtos orgânicos & Incluído & Incluído & $0,0 \%$ \\
\hline
\end{tabular}




\begin{tabular}{|c|c|c|c|c|}
\hline Enquadramento & Descrição & $\begin{array}{l}\text { Critério } \\
\text { adotado no } \\
\text { estudo }\end{array}$ & $\begin{array}{c}\text { Critério } \\
\text { adotado na } \\
\text { balança } \\
\text { comercial }\end{array}$ & $\begin{array}{l}\text { Ocorrências (\% } \\
\text { do total) }\end{array}$ \\
\hline 80200 & $\begin{array}{l}\text { Exportação sujeita a controle de cota (Cota } \\
\text { Performance Frango), com destino à União } \\
\text { Europeia }\end{array}$ & Incluído & Incluído & $0,0 \%$ \\
\hline 80280 & $\begin{array}{l}\text { Exportação de produtos não geneticamente } \\
\text { modificados, exclusivamente para soja, milho e } \\
\text { seus derivados }\end{array}$ & Incluído & Incluído & $0,0 \%$ \\
\hline 80300 & $\begin{array}{l}\text { Exportação sujeita a controle de cota (Cota FIFO } \\
\text { Frango), com destino à União Europeia }\end{array}$ & Incluído & Incluído & $0,1 \%$ \\
\hline 81101 & $\begin{array}{l}\text { Drawback Suspensão (Notícia Siscomex número } \\
\text { 003, de 20/02/2013) }\end{array}$ & Incluído & Incluído & $5,1 \%$ \\
\hline 81102 & Drawback Suspensão Genérico & Incluído & Incluído & $3,2 \%$ \\
\hline 81103 & Drawback Suspensão Intermediário & Incluído & Incluído & $0,0 \%$ \\
\hline 81104 & Drawback Suspensão Solidário & Incluído & Incluído & $0,0 \%$ \\
\hline 81301 & Exportação sujeita a Registro de Venda & Incluído & Incluído & $0,9 \%$ \\
\hline 81501 & Exportação financiada - PROEX/Equalização & Incluído & Incluído & $1,0 \%$ \\
\hline 81502 & Exportação financiada - PROEX/Financiamento & Incluído & Incluído & $0,9 \%$ \\
\hline 81503 & $\begin{array}{l}\text { Exportação financiada - recursos próprios ou de } \\
\text { terceiros, sem PROEX }\end{array}$ & Incluído & Incluído & $0,1 \%$ \\
\hline 99120 & $\begin{array}{l}\text { Exportação em moeda nacional, exceto as } \\
\text { operações enquadradas no código } 99121\end{array}$ & Incluído & Incluído & $8,8 \%$ \\
\hline 99126 & $\begin{array}{l}\text { FONPLATA - Fundo de Financiamento para o } \\
\text { Desenvolvimento da Bacia do Prata }\end{array}$ & Incluído & Incluído & $0,0 \%$ \\
\hline 80117 & $\begin{array}{l}\text { Devolução de veículos antes da emissão da DI } \\
\text { (portaria MF 306/95) }\end{array}$ & Excluído & Excluído & $\begin{array}{l}\text { Sem ocorrências } \\
\text { na amostra }\end{array}$ \\
\hline
\end{tabular}




\begin{tabular}{|c|c|c|c|c|}
\hline Enquadramento & Descrição & $\begin{array}{c}\text { Critério } \\
\text { adotado no } \\
\text { estudo }\end{array}$ & $\begin{array}{c}\text { Critério } \\
\text { adotado na } \\
\text { balança } \\
\text { comercial }\end{array}$ & $\begin{array}{c}\text { Ocorrências (\% } \\
\text { do total) }\end{array}$ \\
\hline 80118 & $\begin{array}{l}\text { Devolução de bens, exceto veículos, antes da } \\
\text { emissão da DI (Portaria MF 306/95) }\end{array}$ & Excluído & Excluído & $0,0 \%$ \\
\hline 90001 & $\begin{array}{l}\text { Exportação temporária de recipientes/embalagens, } \\
\text { reutilizáveis }\end{array}$ & Excluído & Excluído & $0,2 \%$ \\
\hline 90002 & $\begin{array}{l}\text { Exportação temporária de bens sob a forma de } \\
\text { empréstimo ou aluguel }\end{array}$ & Excluído & Excluído & $0,0 \%$ \\
\hline 90003 & $\begin{array}{l}\text { Exportação temporária de bens destinados a feiras, } \\
\text { exposições e certames semelhantes }\end{array}$ & Excluído & Excluído & $0,0 \%$ \\
\hline 90005 & $\begin{array}{l}\text { Exportação temporária de bens a serem submetidos } \\
\text { a conserto, reparação ou manutenção }\end{array}$ & Excluído & Excluído & $0,3 \%$ \\
\hline 90006 & $\begin{array}{l}\text { Exportação temporária de } \text { matérias-primas } \\
\text { insumos para fins de } \\
\text { transformação }\end{array}$ & Excluído & Excluído & $0,0 \%$ \\
\hline 90007 & $\begin{array}{l}\text { Exportação temporária de minérios e metais } \\
\text { enviados para fins de recuperação ou } \\
\text { beneficiamento }\end{array}$ & Excluído & Excluído & $0,0 \%$ \\
\hline 90008 & $\begin{array}{l}\text { Exportação temporária de animais reprodutores } \\
\text { para cobrição }\end{array}$ & Excluído & Excluído & $0,0 \%$ \\
\hline 90009 & Exportação temporária de obras de arte & Excluído & Excluído & $0,0 \%$ \\
\hline 90010 & $\begin{array}{l}\text { Exportação temporária de material destinado a } \\
\text { testes, exames ou pesquisas com finalidade } \\
\text { industrial ou científica }\end{array}$ & Excluído & Excluído & $0,0 \%$ \\
\hline 90099 & $\begin{array}{l}\text { Outras exportações temporárias não enquadradas } \\
\text { em outros códigos }\end{array}$ & Excluído & Excluído & $0,0 \%$ \\
\hline 90115 & $\begin{array}{l}\text { Exportação temporária de aeronave ou material } \\
\text { aeronáutica a ser submetido a conserto, } \\
\text { manutenção, reparo, revisão ou inspeção no exterior }\end{array}$ & Excluído & Excluído & $0,3 \%$ \\
\hline 99101 & $\begin{array}{l}\text { Exportação sem expectativa de recebimento para } \\
\text { fins de divulgação comercial e envio de amostras }\end{array}$ & Excluído & Excluído & $0,3 \%$ \\
\hline
\end{tabular}




\begin{tabular}{|c|c|c|c|c|}
\hline Enquadramento & Descrição & $\begin{array}{c}\text { Critério } \\
\text { adotado no } \\
\text { estudo }\end{array}$ & $\begin{array}{c}\text { Critério } \\
\text { adotado na } \\
\text { balança } \\
\text { comercial }\end{array}$ & $\begin{array}{l}\text { Ocorrências (\% } \\
\text { do total) }\end{array}$ \\
\hline 99103 & $\begin{array}{l}\text { Exportação sem expectativa de recebimento para } \\
\text { complementação (peso/quantidade) de exportação } \\
\text { anterior }\end{array}$ & Excluído & Excluído & $0,1 \%$ \\
\hline 99106 & $\begin{array}{l}\text { Exportação sem expectativa de recebimento para } \\
\text { indenização de mercadoria sem devolução da } \\
\text { exportada originalmente }\end{array}$ & Excluído & Excluído & $0,1 \%$ \\
\hline 99108 & $\begin{array}{l}\text { Reexportação de mercadoria admitida } \\
\text { temporariamente, exceto operações enquadradas no } \\
\text { código } 99123\end{array}$ & Excluído & Excluído & $0,5 \%$ \\
\hline 99113 & Sem cobertura - derivado de sangue humano & Excluído & Excluído & $0,0 \%$ \\
\hline 99114 & $\begin{array}{l}\text { Exportação sem expectativa de recebimento para } \\
\text { indenização de mercadoria com devolução da } \\
\text { exportada originalmente }\end{array}$ & Excluído & Excluído & $0,0 \%$ \\
\hline 99116 & $\begin{array}{l}\text { Exportação sem expectativa de recebimento para } \\
\text { envio de filmes nacionais para exibição no exterior } \\
\text { à base de "royalties" }\end{array}$ & Excluído & Excluído & $0,0 \%$ \\
\hline 99119 & Retorno de animal estrangeiro, com cria ao pé & Excluído & Excluído & $\begin{array}{l}\text { Sem ocorrências } \\
\text { na amostra }\end{array}$ \\
\hline 99122 & $\begin{array}{l}\text { Exportação sem expectativa de recebimento para } \\
\text { devolução de mercadoria importada (Portarias MF } \\
\text { 150/82, 326/83 e 240/86) }\end{array}$ & Excluído & Excluído & $0,1 \%$ \\
\hline 99123 & $\begin{array}{l}\text { Reexportação de aeronaves e/ou material } \\
\text { aeronáutico }\end{array}$ & Excluído & Excluído & $0,1 \%$ \\
\hline 99124 & $\begin{array}{l}\text { Reexportação de mercadoria admitida em } \\
\text { entreposto aduaneiro, entreposto industrial ou } \\
\text { depósito especial alfandegado (DEA) }\end{array}$ & Excluído & Excluído & $2,0 \%$ \\
\hline 99125 & $\begin{array}{l}\text { Devolução sem expectativa de recebimento de } \\
\text { veículos antes da emissão da DI (Portaria MF } \\
306 / 95 \text { ) }\end{array}$ & Excluído & Excluído & $0,0 \%$ \\
\hline
\end{tabular}




\begin{tabular}{|c|c|c|c|c|}
\hline Enquadramento & Descrição & $\begin{array}{l}\text { Critério } \\
\text { adotado no } \\
\text { estudo }\end{array}$ & $\begin{array}{c}\text { Critério } \\
\text { adotado na } \\
\text { balança } \\
\text { comercial }\end{array}$ & $\begin{array}{c}\text { Ocorrências (\% } \\
\text { do total) }\end{array}$ \\
\hline 99127 & $\begin{array}{l}\text { Devolução sem expectativa de recebimento de } \\
\text { bens, exceto veículos, antes da emissão da DI } \\
\text { (Portaria MF 306/95) }\end{array}$ & Excluído & Excluído & $0,0 \%$ \\
\hline 99128 & $\begin{array}{l}\text { Exportação sem expectativa de recebimento para } \\
\text { envio de bens sob a forma de arrend. operacional } \\
\text { com prazo acima } 360 \text { dias. }\end{array}$ & Excluído & Excluído & $\begin{array}{c}\text { Sem ocorrências } \\
\text { na amostra }\end{array}$ \\
\hline 99199 & $\begin{array}{l}\text { Outras exportações sem expectativa de recebimento } \\
\text { para envio de bens ao exterior não enquadradas em } \\
\text { outros códigos }\end{array}$ & Excluído & Excluído & $0,5 \%$ \\
\hline 80101 & Exportação para uso e consumo a bordo & Excluído & Incluído & $1,7 \%$ \\
\hline 80102 & $\begin{array}{l}\text { Exportação em consignação, exceto produtos dos } \\
\text { capítulos } 06 \text { a } 08\end{array}$ & Excluído & Incluído & $0,3 \%$ \\
\hline 80106 & Exportação de material usado, nacional & Excluído & Incluído & $0,0 \%$ \\
\hline 80107 & Regime de depósito alfandegado certificado (DAC) & Excluído & Incluído & $0,1 \%$ \\
\hline 80111 & $\begin{array}{l}\text { Venda no mercado interno a não residente no pais, } \\
\text { capítulo } 71\end{array}$ & Excluído & Incluído & $0,6 \%$ \\
\hline 80112 & $\begin{array}{l}\text { Venda em lojas francas a passageiros com destino } \\
\text { ao exterior, capítulo } 71\end{array}$ & Excluído & Incluído & $0,1 \%$ \\
\hline 80114 & $\begin{array}{l}\text { Exportação em consignação, exclusivamente } \\
\text { produtos dos capítulos } 06 \text { a } 08\end{array}$ & Excluído & Incluído & $0,0 \%$ \\
\hline 80115 & Venda a prazo no mercado interno, capítulo 71 & Excluído & Incluído & $0,0 \%$ \\
\hline 80120 & $\begin{array}{l}\text { Exportação de material nacionalizado, novos ou } \\
\text { usados }\end{array}$ & Excluído & Incluído & $0,7 \%$ \\
\hline 80122 & $\begin{array}{l}\text { Exportação em consignação de mercadorias } \\
\text { classificadas nas posições } 7103 ; 7113 \text { e } 7116 \text { da } \\
\text { NCM }\end{array}$ & Excluído & Incluído & $\begin{array}{l}\text { Sem ocorrências } \\
\text { na amostra }\end{array}$ \\
\hline
\end{tabular}




\begin{tabular}{|c|c|c|c|c|}
\hline Enquadramento & Descrição & $\begin{array}{c}\text { Critério } \\
\text { adotado no } \\
\text { estudo }\end{array}$ & $\begin{array}{c}\text { Critério } \\
\text { adotado na } \\
\text { balança } \\
\text { comercial }\end{array}$ & $\begin{array}{c}\text { Ocorrências (\% } \\
\text { do total) }\end{array}$ \\
\hline 80130 & $\begin{array}{l}\text { Exportação ao amparo do regime especial de } \\
\text { importação de insumos (RECOM) }\end{array}$ & Excluído & Incluído & $\begin{array}{c}\text { Sem ocorrências } \\
\text { na amostra }\end{array}$ \\
\hline 80140 & $\begin{array}{l}\text { Regime aduaneiro especial de exportação e } \\
\text { importação de bens destinados a exploração e } \\
\text { produção de petróleo e gás natural (Repetro) }\end{array}$ & Excluído & Incluído & $0,0 \%$ \\
\hline 80150 & Exportação FICTA (Lei 9.826, artigo 6, inciso ii) & Excluído & Incluído & $0,0 \%$ \\
\hline 80160 & Exportação FICTA (Lei 9.826, artigo 6, inciso iii) & Excluído & Incluído & $0,0 \%$ \\
\hline 80190 & Exportação de energia elétrica & Excluído & Incluído & $\begin{array}{c}\text { Sem ocorrências } \\
\text { na amostra }\end{array}$ \\
\hline 81600 & Energia elétrica/potência & Excluído & Incluído & $\begin{array}{c}\text { Sem ocorrências } \\
\text { na amostra }\end{array}$ \\
\hline 81700 & $\begin{array}{l}\text { Exportação de bens objeto de autorização para } \\
\text { movimentação de bens submetidos ao RECOF } \\
\text { (AMBRA) }\end{array}$ & Excluído & Incluído & $\begin{array}{c}\text { Sem ocorrências } \\
\text { na amostra }\end{array}$ \\
\hline 90011 & $\begin{array}{l}\text { Exportação temporária de bens sob a forma de } \\
\text { arrendamento operacional com prazo acima de } 360 \\
\text { dias }\end{array}$ & Excluído & Incluído & $\begin{array}{c}\text { Sem ocorrências } \\
\text { na amostra }\end{array}$ \\
\hline 90012 & $\begin{array}{l}\text { Exportação temporária de bens sob a forma de } \\
\text { arrendamento operacional com prazo até } 360 \text { dias }\end{array}$ & Excluído & Incluído & $\begin{array}{c}\text { Sem ocorrências } \\
\text { na amostra }\end{array}$ \\
\hline 90013 & $\begin{array}{l}\text { Exportação temporária de ferramentas destinadas às } \\
\text { atividades de manutenção e assistência técnica de } \\
\text { aeronaves exportadas de fabricação nacional } \\
\text { estacionadas no exterior }\end{array}$ & Excluído & Incluído & $\begin{array}{c}\text { Sem ocorrências } \\
\text { na amostra }\end{array}$ \\
\hline 90014 & $\begin{array}{l}\text { Exportação temporária de matérias-primas ou } \\
\text { insumos para fins de beneficiamento ou } \\
\text { transformação (commodities agrícolas) }\end{array}$ & Excluído & Incluído & $\begin{array}{c}\text { Sem ocorrências } \\
\text { na amostra }\end{array}$ \\
\hline 99104 & $\begin{array}{l}\text { Exportação sem expectativa de recebimento para } \\
\text { fins de doação de bens (atividades religiosas, } \\
\text { filantrópicas, etc.) }\end{array}$ & Excluído & Incluído & $0,0 \%$ \\
\hline
\end{tabular}




\begin{tabular}{|c|c|c|c|c|}
\hline Enquadramento & Descrição & $\begin{array}{c}\text { Critério } \\
\text { adotado no } \\
\text { estudo }\end{array}$ & $\begin{array}{c}\text { Critério } \\
\text { adotado na } \\
\text { balança } \\
\text { comercial }\end{array}$ & $\begin{array}{c}\text { Ocorrências (\% } \\
\text { do total) }\end{array}$ \\
\hline 99107 & $\begin{array}{l}\text { Exportação sem expectativa de recebimento para } \\
\text { envio de bens sob a forma de herança }\end{array}$ & Excluído & Incluído & $\begin{array}{l}\text { Sem ocorrências } \\
\text { na amostra }\end{array}$ \\
\hline 99109 & $\begin{array}{l}\text { Exportação sem expectativa de recebimento para } \\
\text { envio de partes e peças destinadas a reparação de } \\
\text { navios com bandeira brasileira }\end{array}$ & Excluído & Incluído & $0,0 \%$ \\
\hline 99110 & $\begin{array}{l}\text { Exportação sem expectativa de recebimento para } \\
\text { envio de material para manutenção de rota de voo } \\
\text { de empresa aérea brasileira no exterior }\end{array}$ & Excluído & Incluído & $0,1 \%$ \\
\hline 99111 & $\begin{array}{l}\text { Exportação sem expectativa de recebimento para } \\
\text { envio de peças sobressalentes sob contrato de } \\
\text { garantia }\end{array}$ & Excluído & Incluído & $0,0 \%$ \\
\hline 99112 & $\begin{array}{l}\text { Exportação sem expectativa de recebimento para } \\
\text { envio de bens sob a forma de investimento de } \\
\text { capital brasileiro no exterior }\end{array}$ & Excluído & Incluído & $0,0 \%$ \\
\hline 99115 & $\begin{array}{l}\text { Exportação sem expectativa de recebimento de } \\
\text { combustíveis e óleos lubrificantes para } \\
\text { embarcações e aeronaves de empresa brasileira com } \\
\text { linhas internacionais regulares }\end{array}$ & Excluído & Incluído & $0,0 \%$ \\
\hline 99117 & Sem cobertura - encomendas & Excluído & Incluído & $\begin{array}{l}\text { Sem ocorrências } \\
\text { na amostra }\end{array}$ \\
\hline 99121 & $\begin{array}{l}\text { Exportação sem expectativa de recebimento para } \\
\text { envio de bens para uso e consumo a bordo }\end{array}$ & Excluído & Incluído & $0,2 \%$ \\
\hline 99129 & $\begin{array}{l}\text { Exportação sem expectativa de recebimento para } \\
\text { envio de bens sob forma de arrendamento } \\
\text { operacional com prazo de até } 360 \text { dias }\end{array}$ & Excluído & Incluído & $\begin{array}{c}\text { Sem ocorrências } \\
\text { na amostra }\end{array}$ \\
\hline 99130 & $\begin{array}{l}\text { Exportação sem expectativa de recebimento ao } \\
\text { amparo do regime especial de importação de } \\
\text { insumos (RECOM) }\end{array}$ & Excluído & Incluído & $\begin{array}{c}\text { Sem ocorrências } \\
\text { na amostra }\end{array}$ \\
\hline
\end{tabular}




\begin{tabular}{cllcc}
\hline Enquadramento & Descrição & $\begin{array}{c}\text { Critério } \\
\text { adotado no } \\
\text { estudo }\end{array}$ & $\begin{array}{c}\text { Critério } \\
\text { adotado na } \\
\text { balança } \\
\text { comercial }\end{array}$ & $\begin{array}{c}\text { Ocorrências (\% } \\
\text { do total) }\end{array}$ \\
\hline 99131 & $\begin{array}{l}\text { Exportação sem expectativa de recebimento para } \\
\text { envio de partes, peças, componentes e/ou } \\
\text { acessórios destinados a atividade de manutenção e } \\
\text { assistência de aeronaves exportadas de fabricação } \\
\text { nacional estacionadas no exterior }\end{array}$ & Excluído & Incluído & $0,2 \%$ \\
\hline 99132 & $\begin{array}{l}\text { Reexportação de recipientes/embalagens, } \\
\text { reutilizáveis, admitidos temporariamente }\end{array}$ & Excluído & Incluído \\
\hline
\end{tabular}

Nota: A última coluna refere-se a ocorrências em uma amostra preliminar de 777 mil registros de exportação com data de criação entre 1995 e 2012. Nesta amostra, $92,7 \%$ dos registros possuem apenas um enquadramento, 5,8\% possuem apenas dois enquadramentos, e $1,4 \%$ possuem três ou mais enquadramentos. 